\title{
Complex evaluation of the Kiskunhalas-NE fractured metamorphic
} hydrocarbon reservoir

A Kiskunhalas-ÉK repedezett metamorf szénhidrogén rezervoár komplex értékelése

$\mathrm{PhD}$ Thesis

Author:

Ágnes Fiser-Nagy

Supervisor:

Tivadar M. Tóth

head of department, professor

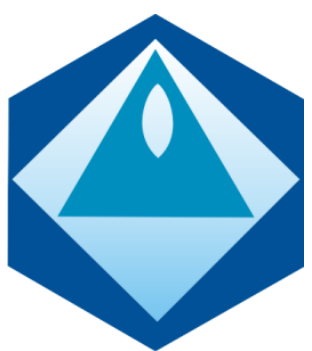

Department of Mineralogy Geochemistry and Petrology

Faculty of Science and Informatics

University of Szeged 


\section{TABLE OF CONTENTS}

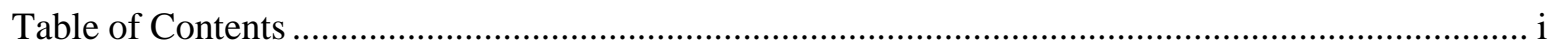

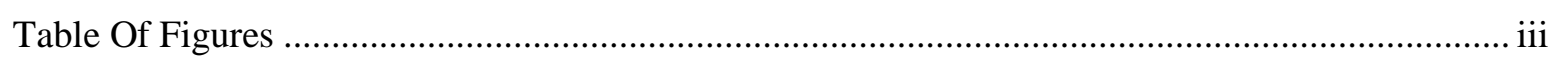

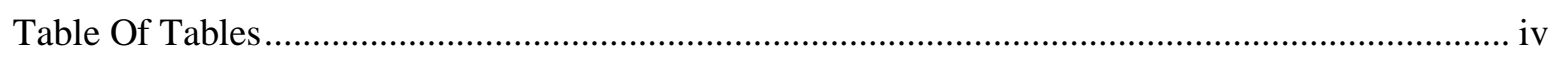

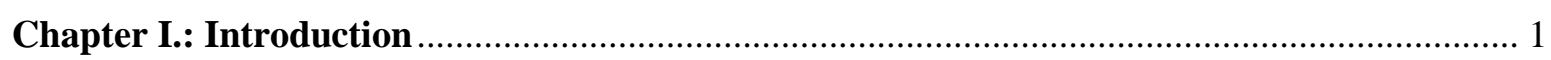

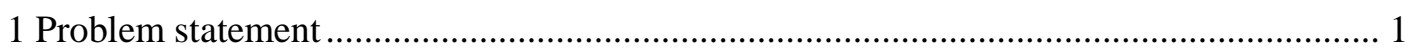

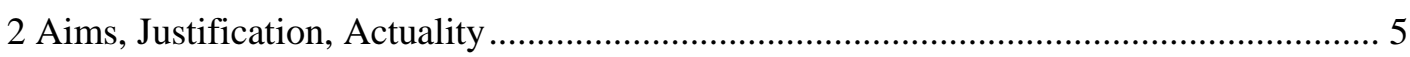

Chapter II.: Petrology and tectonic evolution of the Kiskunhalas-NE fractured hydrocarbon

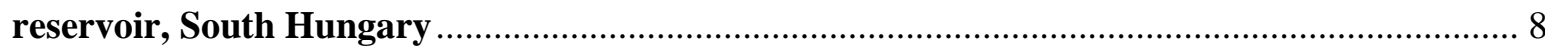

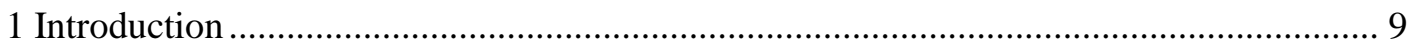

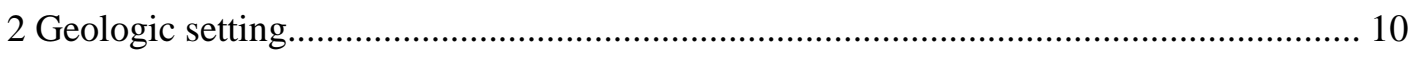

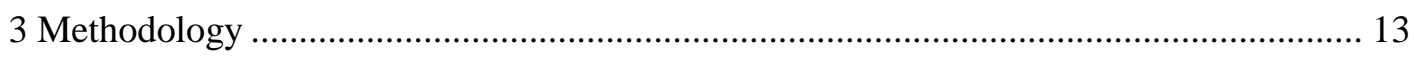

3.1 Carbonaceous material thermometer by Raman microspectroscopy..................... 13

3.2 Sutured quartz grains as a deformation-related thermometer.............................. 15

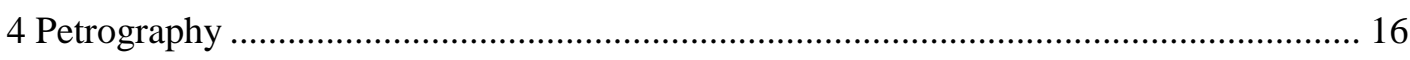

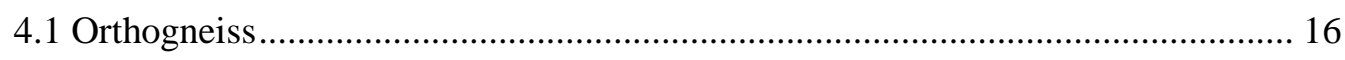

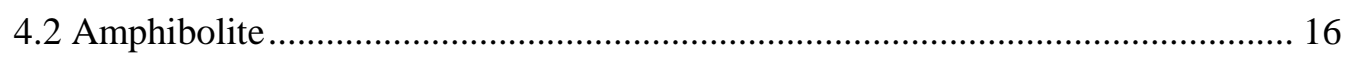

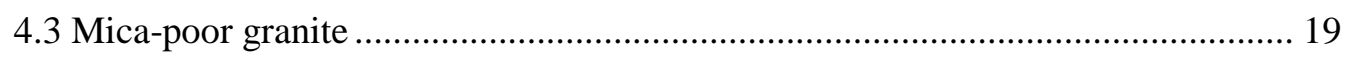

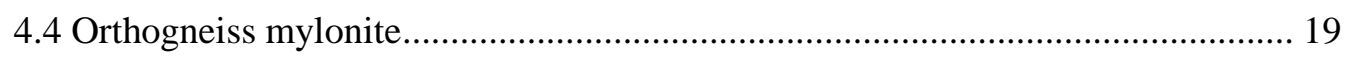

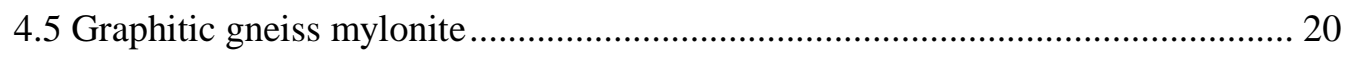

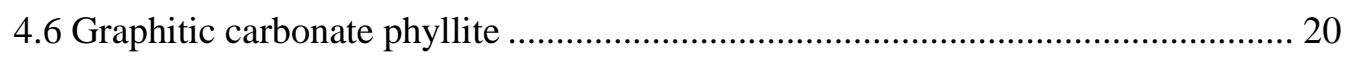

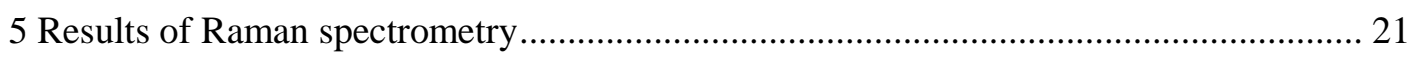

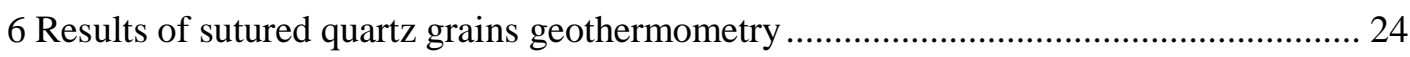

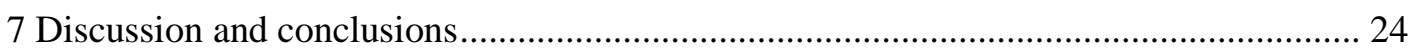

7.1 Interpretation of the results of Raman spectrometry and the CM thermometer .... 24

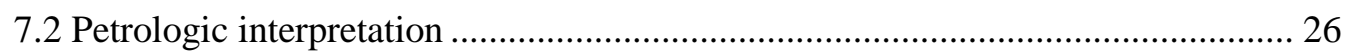

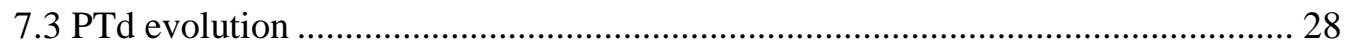

Chapter III.: Integrated core study of a fractured metamorphic HC-reservoir; Kiskunhalas-

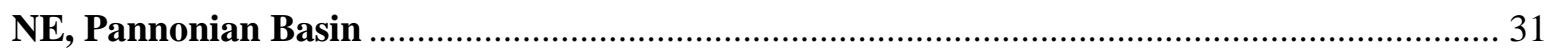

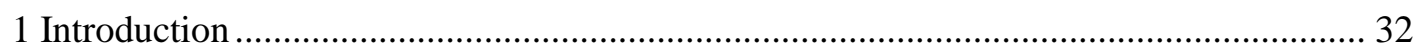

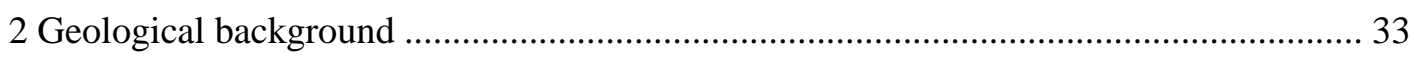

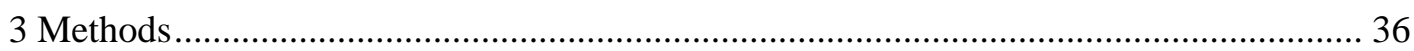

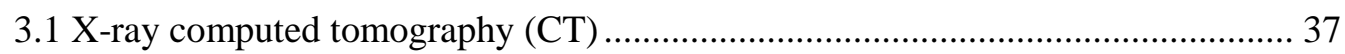

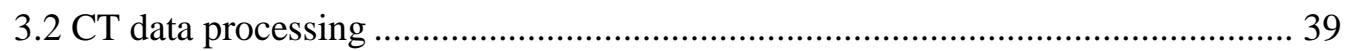

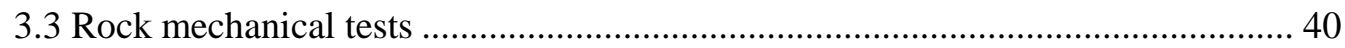


3.4 Statistical methods for data processing ……................................................... 44

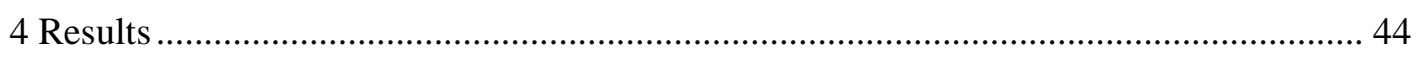

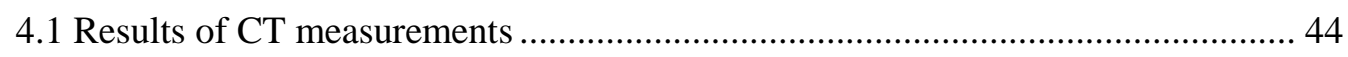

4.2 Results of CT data processing ........................................................................ 44

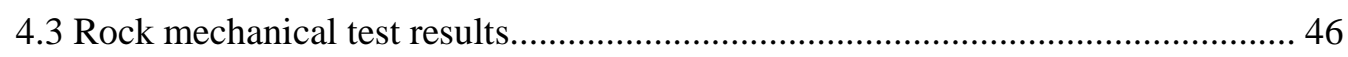

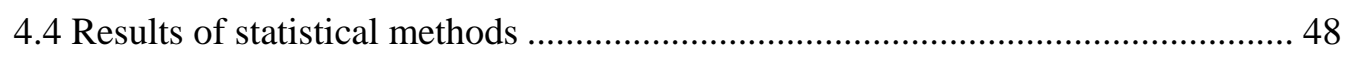

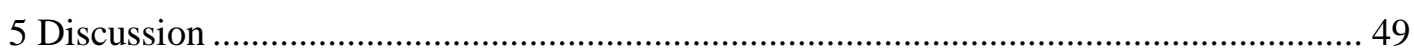

5.1 The nature of the KIHA-NE reservoir rocks ...................................................... 49

5.2 The provoked fracturing of the rock types ........................................................... 51

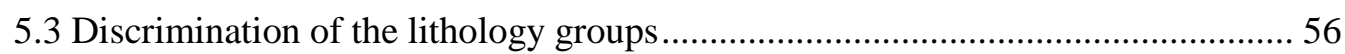

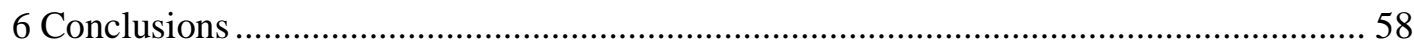

Chapter IV.: Lithology identification with well-log interpretation in the metamorphic

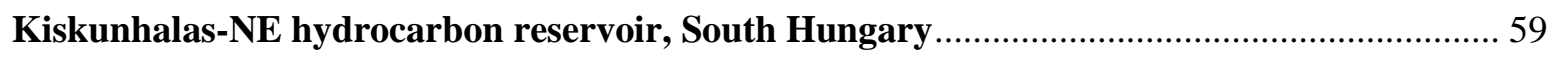

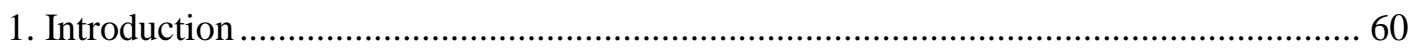

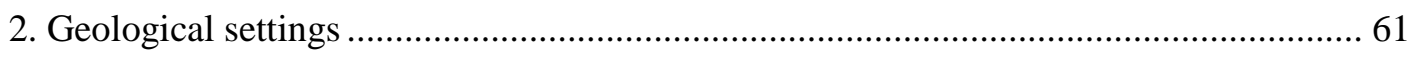

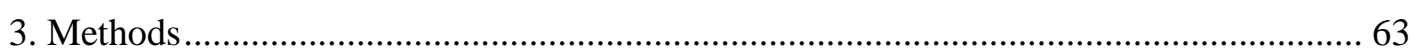

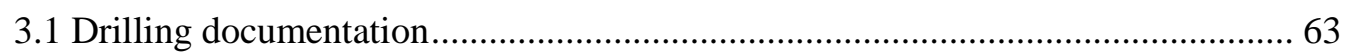

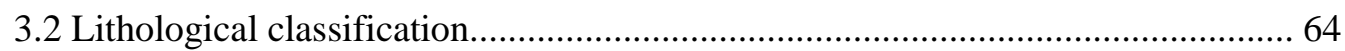

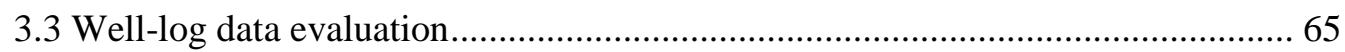

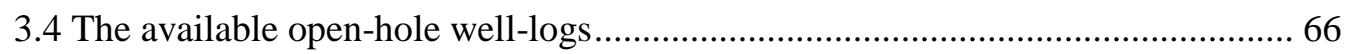

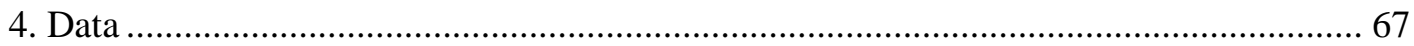

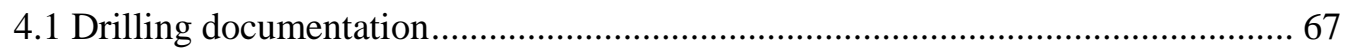

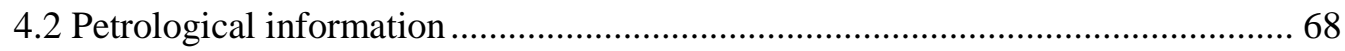

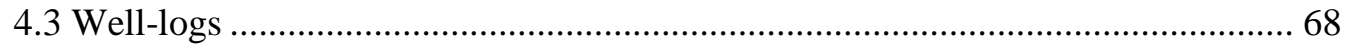

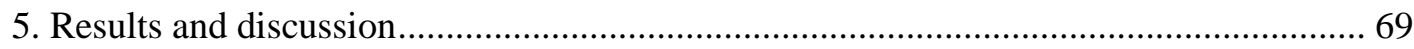

5.1 Separation and identification of the orthogneiss and the mylonitic lithologies..... 69

5.2 Estimation of the boundary between orthogneiss and mylonitic lithologies ......... 72

5.4 Spatial extension of the estimated lithology boundaries ....................................... 79

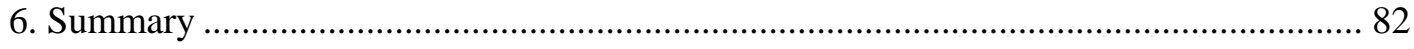

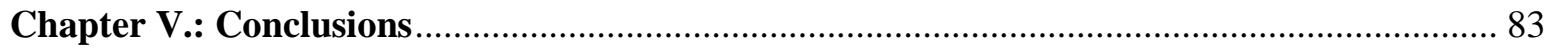

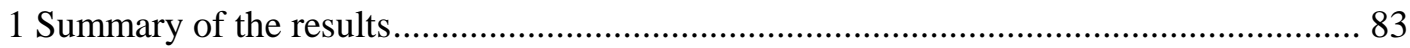

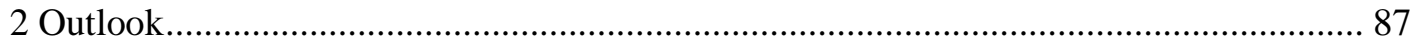

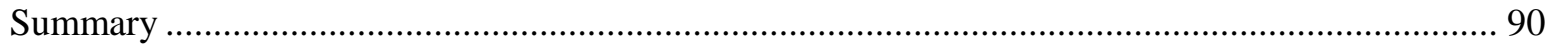

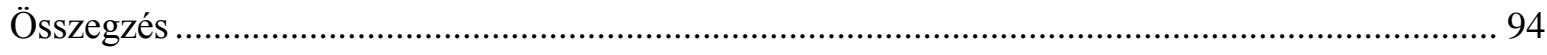

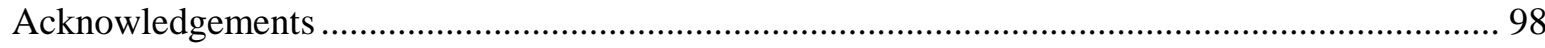

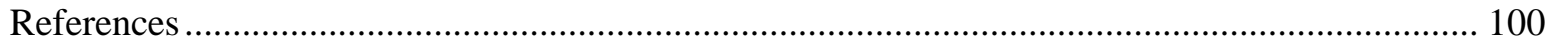




\section{TABLE OF Figures}

Fig. I.1 Elements of the petroleum system in the Pannonian Basin. The source rocks and the reservoir formations are mainly Paleogene and Neogene in age, subordinate Mesozoic formations. In the course of the migration the Paleozoic crystalline basement also takes part in the accumulation. After Horváth \& Tari, in: Mészáros E.-Schweitzer (2002).......................... 2 Fig. I. 2 Simplified petrological framework model of the Szeghalom Dome, and the hypothetical flow path; after M. Tóth et al. (2007). ............................................................ 3 Fig. II.1. Location of the Kiskunhalas-NE Field on the Pre-Cenozoic geologic map of

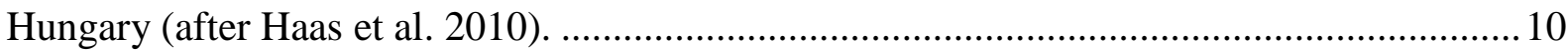

Fig. II.2. Rock types of the KIHA-NE Field................................................................... 19

Fig. II.3. Typical examples of the first-order regions of the Raman spectra of the measured

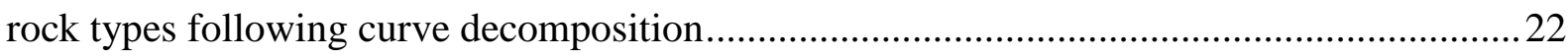

Fig. II.4. Distribution of R2 values of graphitic gneiss mylonite .......................................22

Fig. II.5. Estimation of the fractal dimension values (D) of serrated grain boundaries measured on quartz grains from graphitic gneiss mylonite and gneiss mylonite, respectively.

Fig. II.6. The ideal rock column for the KIHA-NE field with the characteristic temperature data for the metamorphic, structural evolutions of the subsequent rock units. 28

Fig. II.7. A hypothetical outline sketched for the development of the current rock bodies along the mylonitic shear zone.

Fig. III.1. Simplified geological map of the Pannonian Basin in the Alpine-Carpathian-Dinaric system showing the position of the Kiskunhalas and the neighbouring fields. The dashed lines referred to the subunits of Tisza Unit 34

Fig.III. 2. The idealised rock column of KIHA-NE Field (after Nagy and M. Tóth 2012)...... 36

Fig. III.3. Stress-strain diagram of a rock showing the stages of crack development (after Martin 1993).

Fig.III.4. Characteristic CT scan section of the treated samples considering the sample orientation. The indicated CFL and D values are valid for the presented sample. The evolved fracture network is shown by black colour inside the samples.

Fig. III.5. a) Characteristic histogram of the intact and crushed samples; b) boxplot of the mode values of the HU.

Fig. III.6. Characteristic stress-stain curves of: (a) orthogneiss, (b) orthogneiss mylonite, (c) graphitic gneiss mylonite parallel, (d) graphitic gneiss mylonite perpendicular.

Fig. III.7. The concept of the Modulus Ratio (MR): a strength-deformation representation for rock materials and rock masses (Deere and Miller 1966) with the characteristic intervals of the metamorphic and sedimentary rocks.

Fig. III.8. Cross plots of KIHA-NE data $(n=22)$ : (a) Wd $-\sigma c$, (b) CFL-D, (c) D -Wd , (d)

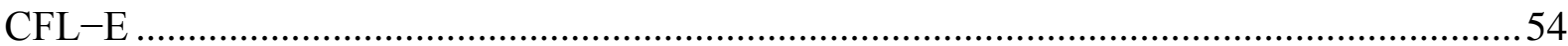

Fig. III.9. Histograms of the discriminant scores for the lithology groups. ............................57

Figure IV.1. a) Location of the Kiskunhalas-NE field in the Pannonian Basin (After Haas et al. 2010). b) Representative macroscopic picture of the litotypes in the order of the ideal rock column and metamorphic evolution of them (after Nagy \& M. Tóth, 2012). 
Figure IV.3. Plots of gneiss and mylonitic lithologies: a) Gamma-Resistivity plot of well-Q; b) Gamma-Resistivity log of well-J; c) Sonic - Density plot of well-F; d) MN plot of well-F.

Figure IV.4. Discriminant function analysis (D1) of gneiss and mylonite with density, sonic, neutron logs: a) histogram of the discriminant scores (D1) of well-F; b) discriminant scores (D1) of well-F along the well; c) MN plot of well-119; d) discriminant scores (D1) of well119 along the well.

Figure IV.5. Discriminant function analysis (D2) of gneiss and mylonite with density and neutron logs: a) histogram of the discriminant scores (D2) of well-F; b) discriminant scores (D2) of well-N along the well. Discriminant function analysis (D3) of gneiss and mylonite with sonic and neutron logs: c) histogram of the discriminant score(D3) of well-F; d) discriminant scores of well-O along the well. 74

Figure IV.6. Discriminant function analysis (D4) of gneiss and mylonite with neutron: a) histogram of the discriminant scores of well-F; b) discriminant scores (D4) of well-Q along the well; c) histogram of the discriminant score (D5) of well-Q d) discriminant scores (D5) of well-F along the well.

Figure IV.7. The a) neutron-density, the b) gamma-resistivity and the c) MN plot of the well$\mathrm{R}$; d) results of the discriminant function analysis (D6) for graphitic carbonate phyllite and mylonite in the well-R.

Figure IV.8. KIHA-NE wells situated on the metamorphic topography, with the ten hydraulic

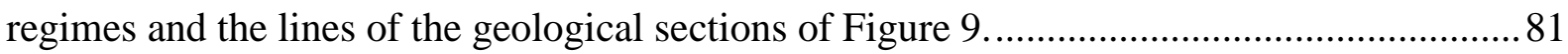

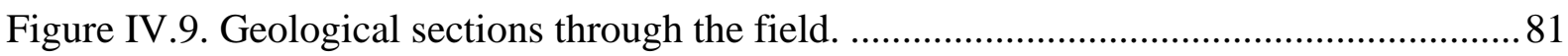

Fig. V.1. Summary of the result for the Kiskunhalas-NE field ................................................. 84

\section{TABLE OF TABLES}

Table II.1. Mean values and standard deviation (s) of the parameters (position, full width at half maximum FWHM) obtained from decomposition of Raman spectra of the measured

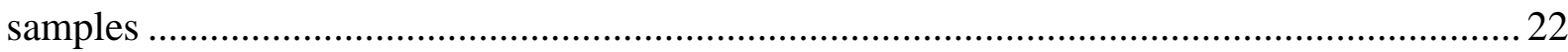

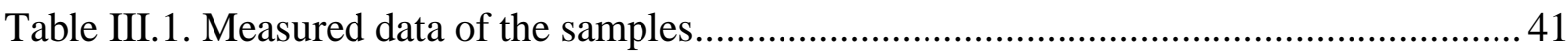

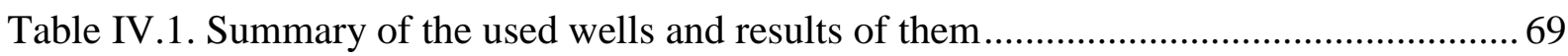




\section{CHAPTER I.}

\section{INTRODUCTION}

\section{Problem statement}

Although nearly all fluid reservoirs contain a certain amount of natural fracturing, naturally fractured reservoirs include only those where the fractures have an effect (either positive or negative) on fluid flow. Although most of the world's hydrocarbon accumulations occur in sandstone, carbonate (e.g., Ghaba North field in Oman - Al-Hadhrami and Blunt 2001, Qarn Alam Field in Oman - Zellou et al. 2003, Tempa Rossa field, southern Apennines, Italy - Aydin 2000) igneous (e.g., Liaohe oilfield in China - Pan et al. 2002, Qingshen gas field in the Songliao Basin, NE China - Feng 2008, Serie Tobífera unit in the Austral Basin and the Precuyano unit in the Neuquén Basin, Argentina - Sruoga and Rubinstein 2007, Schutter 2003) and metamorphic (e.g., La Paz Field, Maracaibo Basin, Venezuela - Nelson et al. 2000, Liaohe basin, China - Luo et al. 2005, Li et al. 2009, Travis Peak Formation, East Texas basin - Becker et al. 2010) rocks can also make acceptable reservoir rock. The fractures form a kind of secondary porosity in these rock bodies which could be generated by the following (Aguilera, 1995):

(1) faulting tends to generate cracks along the line of fault and could produce a zone of dilatancy, which is a good way for the migration and accumulation of petroleum (e.g., Lü et al. 2008);

(2) deep erosion of overburden that permits the upper parts to expand, uplift and fracture through planes of weakness (e.g., Gudmundsson 1987);

(3) volume shrinkage as in the case of shales that lose water, cooling of igneous rocks and desiccation of sedimentary rocks (e.g., Areshev et al. 1992);

(4) paleokarstification and solution collapse (e.g., Gu et al. 2002);

(5) fluid pressure release when pore fluid pressure approaches the lithostatic pressure.

The storage capacity of naturally fractured reservoirs varies extremely, depending on (1) the degree of fracturing in the formation and value of primary porosity (Aguilera, 1995); (2) the fracture density and number of intersecting fracture sets (Salah and Alsharhan 1998); (3) the orientation of fracturing (Salah and Alsharhan 1998); (4) the diagenetic processes and related alteration phases of the basement which can also play an important role in reservoir characterisations (Salah and Alsharhan 1998); and (5) the morphology of the fractures, which 
relates to the shape of natural fractures and four distinguishable types: open, deformed, mineral-filled, and vuggy fractures (Nelson 2001). The migration and accumulation of petroleum in naturally fractured reservoirs is possible in a dilatancy zone due to the vacuum produced by the fractures. In this theory (McNaugthon and Grab 1975) the fractures were formed after the generation of petroleum. According to another theory, the fractures usually form before the migration of petroleum; in the first step, fractures may generate in an uplifted hill, followed by coarse debris accumulation on the slopes. Afterwards, the hill is deeply buried by continuous subsidence; petroleum is generated and migrates up to the crest of the buried hill. As a consequence petroleum may be trapped in both the sediments and the fractured basement (McNaugthon and Grab 1975).
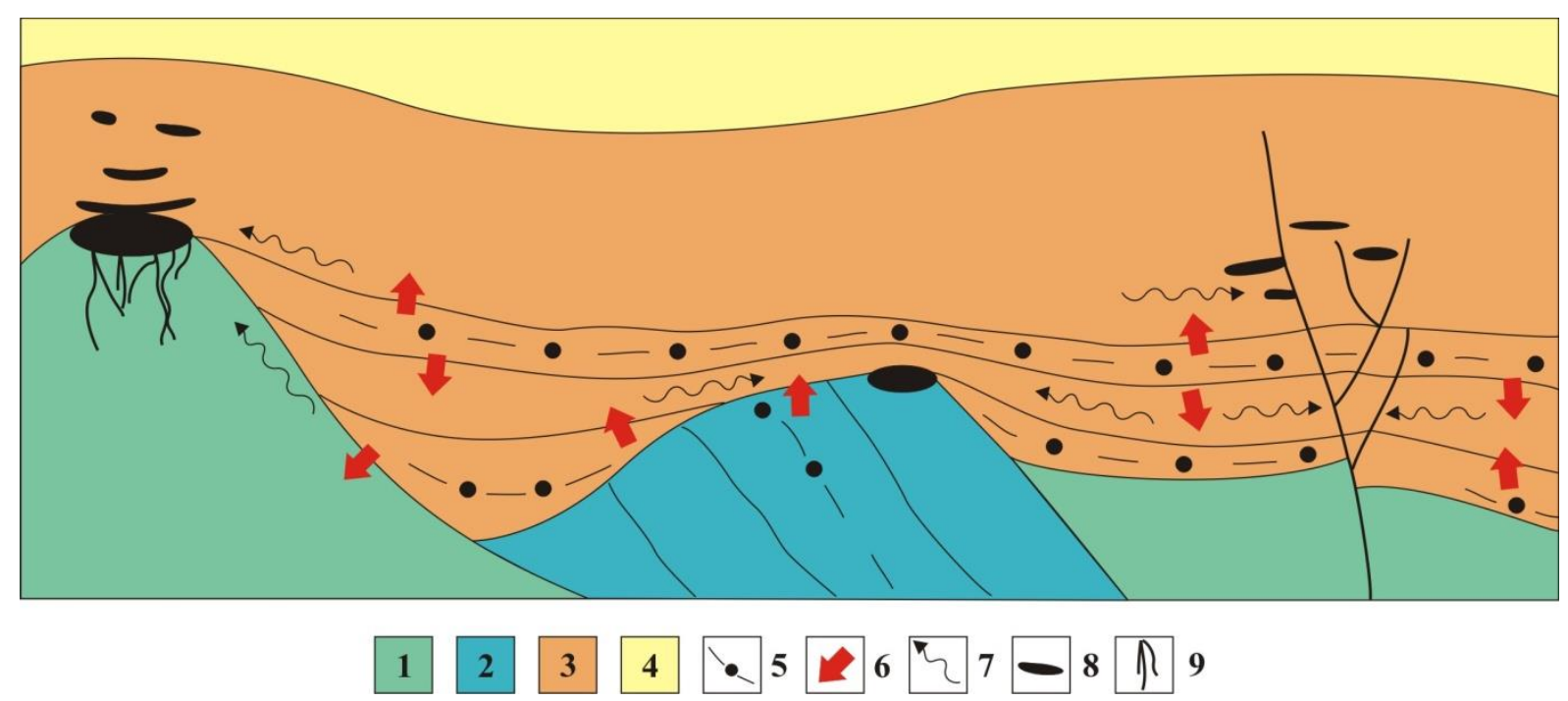

Fig. I.1 Elements of the petroleum system in the Pannonian Basin. The source rocks and the reservoir formations are mainly Paleogene and Neogene in age, subordinate Mesozoic formations. In the course of the migration the Paleozoic crystalline basement also takes part in the accumulation. After Horváth \& Tari, in: Mészáros E.-Schweitzer (2002)

Legend: 1 -Paleozoic formations, 2 - Mesozoic formations, 3 - Paleogene and Neogene foramtions, 4 - Quaternary formations, 5 - source rocks, 6 - migration pathways of oil, 7 - migration pathways of gas, 8 - reservoirs in the basin, 9 - reservoirs in the basement.

The Pannonian Basin, surrounded by the Alpine-Carpathian-Dinaric orogenic belt, is filled with thick sedimentary layers due to basin subsidence in the Tertiary ages (Horváth et al. 1988). According to Teleki et al. (1994) most of the currently explored hydrocarbons come from the middle Miocene synrift sedimentary rocks and middle Miocene-Pliocene postrift sedimentary rocks; suggesting that percolation into the basement happened coeval to the main subsidence phase of the basin. A favourable circumstance was the contemporaneous high geothermic gradient of the basin (Hajnal et al. 1996). As a result the source rocks are at a depth of about one and a half kilometres, which would have required temperatures of oil and 
gas formation to be reached. The reservoir rocks in the Pannonian Basin are mainly sandstones of Pannonian age, but there may also be Eocene, Oligocene and Miocene clastic sedimentary rocks, fractured Mesozoic limestones and dolomites, and Palaeozoic crystalline rocks, which originate from the direction of younger source rock with lateral migration of hydrocarbons reached (Fig. I.1). The Pannonian reservoirs usually form curved arches over the Palaeozoic highs (Dank 1985).

M. Tóth et al. (2007) introduced a possible explanation in case of the Szeghalom Dome, regarding how the fractured metamorphic basement could develop as a hydrocarbon reservoir. In such cases, when the basement is approximately plane, no highs and deeps occur, low permeable and porous sedimentary layers (clay marl, calcareous marl) cover it and isolate the underlying basement rocks from further basin filling sediments. However, in several cases the basement is characterised morphologically by deep basins and trenches, with uplifted highs among them. Most of the crystalline highs exhumed during the Middle Miocene follow core complex formation mechanisms (Horváth et al. 2006, Posgay et al. 2006) and so reached the surface or a near surface position. In fact, the uplifted highs formed islands in the Pannonian Sea, which usually caused the absence of the impermeable sequence of the Endröd Formation (clay marl) above the highs (Fig. I. 2).

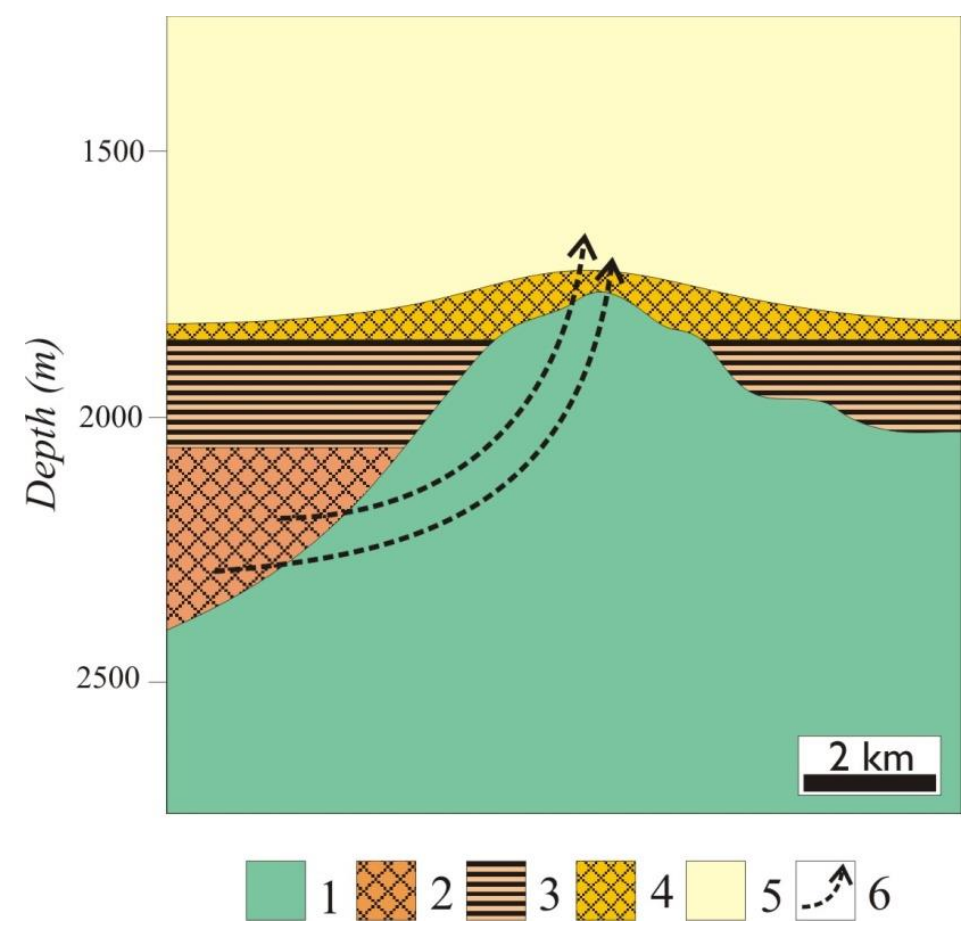

Fig. I. 2 Simplified petrological framework model of the Szeghalom Dome, and the hypothetical flow path; after M. Tóth et al. (2007).

Legend:

1 - metamorphic high,

2 - Békés Formation

(conglomerate),

3 - Endröd Fromation (clay marl),

4 - abrasion conglomerate,

5 - Szolnok Formation

(sandstone),

6 - hypothetical flow path.

The fracture system of these one-time islands played an important role as a flow path in the course of the early diagenesis of the basin sediments (Juhász et al. 2002). During the following thermal subsidence phase of the basin evolution, these fracture systems were 
relegated to the background and closed. Because the tectonic inversion motions are still active, the metamorphic highs repeatedly uplift, and the previously closed fractures could reactivate and provide pathways for the fluid migration and/or storage, even at present. This mechanism enables the tapping of the over-pressured deep-basins by the chimney effect (Fig. I. 2). Although this model can be generalized for the whole Pannonian Basin, the individual characteristics of each reservoir may cause important differences in details. The lithology dependent rheological characteristics, fracture tendency, and fracture network, or the geometry of the permeable and impermeable rock bodies, as well as the presence and location of a shear zone can define the most essential differences.

The Kiskunhalas-NE (KIHA-NE) hydrocarbon field has been produced since the mid1970s. In this area more than one reservoir block exists; there is a northern reservoir in the Palaeozoic metamorphic basement and a southern one in the Mesozoic carbonate basement. The reserving formations from different ages and material (Palaeozoic metamorphic rocks, Mesozoic carbonates and Miocene sediments) in certain cases behave as one hydraulic regime: the crystalline basement with the Miocene conglomerate, and the crystalline basement with the Mesozoic carbonates. The Miocene formations could also behave as an independent hydraulic regime. They are mainly oil reservoirs with gas cap (Dank 1985, and unpublished industrial reports). The focus of the present study is the reservoir in the metamorphic basement. Several different publications (T. Kovács 1973, Árkai 1978, Cserepes 1980, T. Kovács and Kurucz 1984, Cserepes-Meszéna 1986, Árkai 1993) and unpublished industrial reports noted several types of lithologies in the crystalline basement (gneiss, micaschist, amphibolite, different mylonitic types, migmatite, and a low-grade phyllite); however, in the interpretation of the reservoir the whole area was handled as a homogeneous block. Actually, the KIHA-NE reservoir has a highly compartmentalized nature, since there are at least ten independent hydraulic regimes in the field. This phenomenon may have several geological causes, such as:

(1) The fault zones can provide good migration pathways and/or storage volume (e.g., Gudmundsson et al. 2001, Schubert and M. Tóth 2003), however, there are several cases where the faults behave as an impermeable zone (e.g., Edwards et al. 1993).

(2) In a reservoir with heterogenic petrological built-up, the different rock types may exhibit different fracture tendencies that can cause various geometries from the unfractured rock masses to highly fractured bodies (e.g., M. Tóth et al. 2004). 
(3) The recent stress field can close the permeable fracture system, and/or open others

(the fractures with the proper orientation) (e.g., Teufel et al. 1991, Heffer and Lean 1993, Laubach et al. 2004).

The basement of the Pannonian Basin is a rather compartmentalized, heterogeneous mosaic of blocks; it has developed through a series of complicated tectonic events since the Variscan ages (e.g., Kovács et al. 2000). This basement is covered by several hundred metres (up to kilometres locally) of thick sediments; for this reason natural basement outcrop does not exist. Thus direct information comes exclusively from wells, borecores, well-logs, and in certain cases seismic sections. The level of exploration is virtually determined by industrial interest regarding the various fluids preserved by the basin sediments and the basement rocks, hydrocarbons, geothermal and drinking water. Therefore, exploration and thus knowledge about the areas without industrial interest in fluids has fallen behind areas which are the focus of such interest. The available data are point like and sporadic, usually archive (more than a decade old), and moreover, amounts of data and samples have decreased during the time elapsed after drilling. Because of this limited database, or even the lack of any data, efforts to get the maximum use out of the information still available are particularly important.

In the case of KIHA-NE field, the situation is similar; there are numerous wells, but the number of borecores is limited, the archive well logs have no wide range, and seismic section is not available. Further valuable information is provided by daily reports of the drilling works and industrial reports and publications. It must be appreciated that the integrated usage of information about the field is especially necessary, and that this may provide the key to better understanding.

\section{Aims, Justification, Actuality}

On the one hand, the present study is situated within basic geological research. From time to time a review of a field is necessary because new methods and novel scientific ideas can enrich existing knowledge regarding those hardly studied fields and their wider geological environment. In this way it will be possible to enrich the highly sporadic information about the crystalline basement of the Pannonian Basin within the wider neighbourhood of the study area.

On the other hand, this research also has an applied geological point of view. Newly acquired knowledge about the field provides more adequate framework regarding the characteristics of the reservoir. This can help to create a better reservoir model which can 
contribute to more effective production, and can provide guidance about field development processes, even including the drilling of new wells. The new methods, data management, or the routine of test series learned or developed in the course of this project could be utilized in the future. The official review of the Kiskunhalas fields in the MOL Plc., begun in 2008, provides actuality for the research. In the wider environment (around Jánoshalma and Kiskunhalas) the RAG (Rohöl-Aufsuchungs Aktiengesellschaft) currently conducts research.

The first objective of this project was to clarify the petrological build-up of the field, because of the contradictory previous descriptions within various publications and reports. In order to classify the lithology units, detailed macroscopic and microscopic examination and, because of the presence of sheared lithologies, prudent texture analyses were carried out. To find the genetic relationships between the identified lithologies, thermometric methods were used. The resulting comprehensive petrography and ideal rock column can be used in the course of further investigations.

The reservoir features of the constituent lithologies of a fractured reservoir can be determined, among other factors, by:

(1) the extent of the fracture tendency,

(2) the quality of communication in the fracture network, which depends on the fracture connections,

(3) and the presence of the preferred orientation in the rock.

Investigations can be carried out on provoked, artificial fracture networks for each lithology of the field with conventional rock mechanical tests and evaluation of CT images. In this way it is possible to determine which lithology has a major role in the fluid storage, and also the main factors that influence these favourable characteristics.

Finally, knowing the essential lithologies of the field and their most important reservoir features, the next obvious question concerns the spatial extension of all lithologies, with special interest on the rock body with the best reservoir parameters. To explore the geometry and the extent of the lithology blocks, each lithology must be identified on open-hole welllogs in order to be able to estimate lithology boundaries, and, finally, to present the results along geological sections. Thereby the structural build-up of the reservoir can be revealed. 
The forthcoming sections comprise a compilation of published and submitted papers about the fractured metamorphic hydrocarbon reservoir of Kiskunhalas-NE. These papers together serve as a state of the art understanding of the petrology, structural built-up and reservoir behaviour of the investigated area. Following the introduction (Chapter I.), Chapter II. focuses on the classification of the lithologies of the KIHA-NE field and their genetic relationships. Subsequently, the reservoir features of the identified rock units are determined by the evaluation of rock mechanical tests and computer tomography (CT) images in Chapter III. Next, Chapter IV. deals with lithology identification and boundary estimation using openhole well-log data. In Chapter $V$. the main results and conclusions of the whole thesis will be presented. An aggregated reference list of all chapters can be found at the end of the dissertation. 


\title{
CHAPTer II.
}

\section{Petrology AND TECTONIC EVOLUTION OF THE}

\section{KISKUNHALAS-NE FRACTURED HYDROCARBON RESERVOIR, SOUTH HUNGARY}

\author{
Ágnes Nagy \\ Department of Mineralogy Geochemistry and Petrology, \\ University of Szeged, Szeged, Hungary \\ agnes.nagy@geo.u-szeged.hu \\ Tivadar M. Tóth \\ Department of Mineralogy Geochemistry and Petrology, \\ University of Szeged, Szeged, Hungary \\ mtoth@geo.u-szeged.hu
}

Central European Geology

Vol. 55/1, 1-22 (2012)

DOI: 10.1556/CEuGeol.55.2012.1.1 


\title{
Petrology and tectonic evolution of the
}

\section{Kiskunhalas-NE fractured hydrocarbon reservoir, South Hungary}

by: Ágnes Nagy, Tivadar M. Tóth

\begin{abstract}
The Kiskunhalas-NE (KIHA-NE) fractured hydrocarbon reservoir is part of the structurally rather complex crystalline basement of the Great Hungarian Plain. In the course of petrologic and thermometric examinations various rock types of the investigated area have been classified and characterized. There are four basic lithological units in the area. In the lowest structural position orthogneiss is common, which according to its petrographic features is assumed to be identical to the orthogneiss body of the adjacent Jánoshalma ( $\mathrm{JH}$ ) basement high (metamorphic peak temperature $T<580{ }^{\circ} \mathrm{C}$ according to Zachar and M. Tóth 2004). The next rock unit upward is the highly mylonitized variety of the orthogneiss with textural features suggesting deformation in an extensional stress regime. In the higher section of the mylonite zone graphitic gneiss mylonite is characteristic, with a peak metamorphic $T$ of $410 \pm$ $45^{\circ} \mathrm{C}$. The lithology in the shallowest position of the area is a graphitic carbonate phyllite, with a $T$ of $375 \pm 15{ }^{\circ} \mathrm{C}$. Estimation of the deformation temperature for both mylonitic rocks results in approximately $T_{\text {def }} \sim 455{ }^{\circ} \mathrm{C}$. All data together suggest that between the top (graphitic carbonate phyllite) and the bottom (orthogneiss) of the ideal rock column there is about $200{ }^{\circ} \mathrm{C}$ peak metamorphic temperature deviation. The two extreme metamorphic blocks probably became juxtaposed along an extensional fault zone in the basement at approximately $15 \mathrm{~km}$ depth.
\end{abstract}

\section{Introduction}

In several places the crystalline basement of the Pannonian Basin accumulates significant amounts of hydrocarbon. Understanding these fractured reservoirs is rather challenging because of the complicated structural evolution of the metamorphic complexes. As there is no surface outcrop in the region, the metamorphic rock bodies can only be examined using the very limited number of core samples. Previous studies of numerous hard rock reservoirs in the Pannonian Basin (Zachar and M. Tóth 2001; Schubert and M. Tóth 2002; M. Tóth et al. 2002; Zachar and M. Tóth 2004; M. Tóth and Zachar 2006; Zachar et al. 2007) nevertheless pointed out that diverse rock types tend to show significantly different fracture characteristics and therefore reservoir behaviour. That is why understanding the lithological framework in each single fractured hydrocarbon field is crucial and requires a detailed study of petrology and microstructures of the given rock types.

In the Kiskunhalas (KIHA)-NE Field 69 wells penetrated the metamorphic basement, but only specific segments of a few of them produce any fluid (water, oil or gas). The depth of 
the oil-water contact is also significantly different in neighbouring wells, suggesting a highly compartmentalized reservoir. Previous studies (Cserepes 1980; T. Kovács and Kurucz 1984; Árkai 1991) suggest many different rock types in the KIHA-NE Field that may exhibit various petrophysical behaviours, providing a possible explanation for the coexistence of permeable and impermeable zones within the metamorphic rock body.

The aim of the present study is to characterize and classify the basement rocks of the poorly-known KIHA-NE Field. Furthermore, we aim at presenting a thorough petrologic characterization of the most important rock types from the research area, sketching physical conditions of their metamorphic evolutions as well as outlining the spatial relationship of the main lithologies. Such a petrologic background may serve as a firm basis for modelling petrophysical properties of the complex rock body at reservoir scale in the future.

\section{Geologic setting}

Inside the Alpine-Carpathian-Dinaric orogenic belt the Pannonian Basin has a structurally rather complex crystalline basement, because of its complicated, multistage tectonic evolution. The essentially unknown Variscan tectonic events were followed by large scale extension during the Early Jurassic and nappe formation in the Cretaceous. Finally, the basement rocks were intensely deformed due to basin subsidence during the Miocene and Pliocene. As a result, at present the basement is a complicated mosaic of blocks with mutually incompatible metamorphic and structural evolutions.

The KIHA-NE Field is situated south of the Mid-Hungarian tectonic zone that separates the Tisza Unit from the Alcapa Unit (Csontos and Nagymarosi 1998). According to recent interpretations the study area is located rather close to the assumed front of the Codru Nappe, which was formed as a result of Cretaceous tectonic activity. Although the KIHA-NE area has never been studied in detail petrologically, there are better-known neighboring metamorphic uplifts. Information concerning the petrologically well-known Jánoshalma High (JH) to the SW (Zachar and M. Tóth 2004; Zachar et al. 2007) and the Tázlár (T) area to the NE may be used for comparing results of the entire, relatively small region of the metamorphic basement (Fig. II.1).

Fig. II.1. Location of the Kiskunhalas-NE Field on the Pre-Cenozoic geologic map of Hungary (after Haas et al. 2010).

Legend: 1. Cretaceous sediments; 2. Cretaceous volcanites; 3. Jurassic sediments; 4. Triassic sediments; 5. Mesozoic rocks in general; 6. Permian rhyolite; 7. Variscan crystalline formations; 8. Unknown basement. 


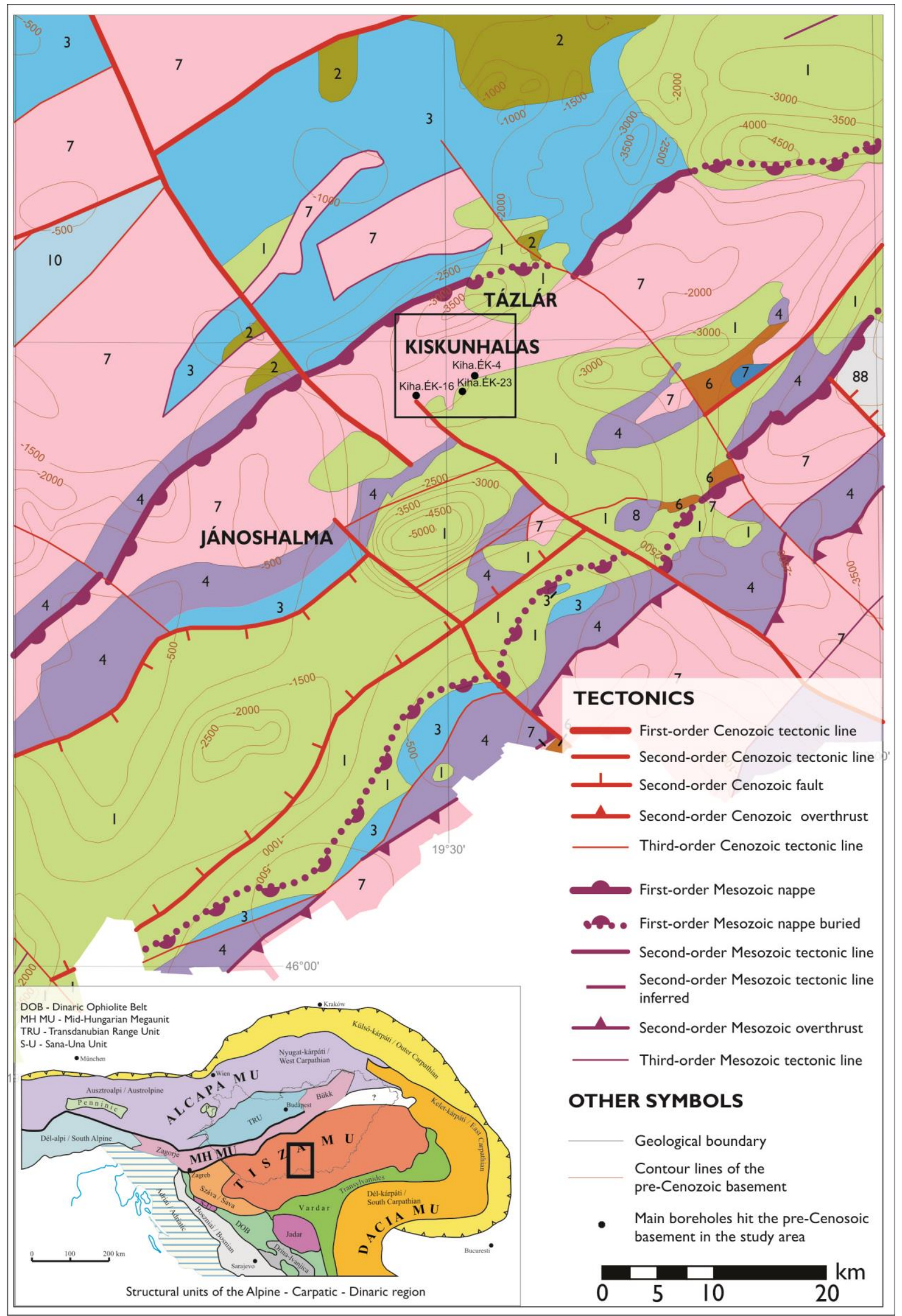

$<$ Fig. II.1 
According to Zachar and M. Tóth (2004) JH is a uniform orthogneiss block with the presence of numerous amphibolite and eclogite enclaves of diverse metamorphic evolutions. Zachar et al. (2007) consider that these enclaves are in fact various xenoliths of the original igneous (granitoid) body and represent rock pieces of the mélange zone of an ancient subduction-accretionary complex. The gneiss body itself exhibits a clear two-phase evolution. Conditions of the first detectable, probably igneous event can only be estimated in a rather wide window of $T \sim 700-850{ }^{\circ} \mathrm{C}$ and $P<0.65 \mathrm{GPa}$. The second phase of the history is characterized by the development of schistosity at $T<580{ }^{\circ} \mathrm{C}$. Due to postmetamorphic ductile deformation, mylonite formed along the retrograde phase under greenschist facies conditions. Brittle deformation and widespread metasomatic overprint further complicated the current structure of the gneiss body. The most common mafic xenoliths are amphibolites and the occurrence of amphibole xenocrysts in the orthogneiss texture is common as well. The only eclogite xenolith is characterized by a $T \sim 710 \pm 10{ }^{\circ} \mathrm{C}$ and $P \sim 2.6 \pm 0.75 \mathrm{GPa}$ peak followed by retrogression during decompression (Zachar et al. 2007). The original granitoid intrusion indicates a peraluminous composition and syn-collision origin (Zachar and M. Tóth 2004).

According to the small number of previous papers dealing with the KIHA-NE Field, gneiss, micaschist, amphibolite, different mylonitic types, migmatite, and a low-grade phyllite variety predominate in the study area, in an unknown structural arrangement (Cserepes 1980; Cserepes-Meszéna 1986; T. Kovács and Kurucz 1984). T. Kovács (1973) suggests that in relation to the general amphibolite facies metamorphism of Variscan age, in some places migmatite and diatexite formed. In the course of the following retrograde metamorphism, mylonite, chlorite schist and sericite schist evolved (Árkai 1991). Árkai $(1978,1991)$ suggests that the protolith of the phyllite was a marly sediment formed under reducing conditions. Using illite crystallinity indices it underwent a very low-grade metamorphism with a peak of about $270-300{ }^{\circ} \mathrm{C}$ (Árkai in Cserepes-Meszéna 1986). Árkai (1991) supposes that the very low-grade phyllite represents an exotic nappe, and consequently its contact to other rock types must be tectonic. Geochemical data infer weathering of the phyllite body under surface conditions.

The Tázlár Field belongs morphologically to the same ridge as KIHA-NE, with highly similar rock types. Nevertheless it has not yet been studied in detail. Gneiss and various mylonite types are common, with subordinate amounts of graphitic carbonate phyllite and relatively fresh amphibolites. Migmatite and related lithologies are not reported from this area (Cserepes 1980). 


\section{Methodology}

In general, the crystalline formations of the Pannonian Basin are deep-seated and are deeply buried beneath a few thousands of meters of Miocene and Pliocene sediments. The metamorphic basement can only be investigated with cores and diverse geophysical methods. In the KIHA-NE region 69 non-oriented wells penetrated the basement; among these only 25 sampled it at different depth intervals, while core recovery was only a few per cent in the case of each well. At present, core samples of 15 wells are available for petrographic study, while several samples have disappeared in the last decades and are represented only by old thin sections. Altogether, more than 100 thin sections were investigated, most of which belong to the collection of the Hungarian Gas and Oil Company (MOL Plc.). In order to make the lithological classification in the study area as detailed as possible, petrographic investigation of each single core sample was carried out. Afterward, microstructural and thermometric examinations were done on selected samples.

\subsection{Carbonaceous material thermometer by Raman microspectroscopy}

During diagenesis and metamorphism of sedimentary rocks the carbonaceous material (CM) contained in it undergoes transformation from disordered CM to fully ordered graphite (graphitization). The degree of organization of metamorphic CM indicates the metamorphic grade, and especially the importance of temperature. The Raman spectra of metamorphic CM exhibit a significant evolution with metamorphic grade (e.g. Wopenka and Pasteris 1993; Yui et al. 1996). The process of graphitization has a strictly irreversible character; thus it primarily depends on the maximum temperature reached along a given PT path (e.g. Beyssac et al. 2002; Beyssac et al. 2004; Wiederkehr et al. 2011; Aoya et al. 2010). Therefore the CM structure is insensitive to retrograde metamorphic overprint or polymetamorphic evolution (Wiederkehr et al. 2011; Beyssac et al. 2002; Wopenka and Pasteris 1993). Due to the high spatial resolution and the short acquisition time, which allows numerous spectra to be recorded and therefore to quantify the sample heterogeneity, Raman spectroscopy appears the most appropriate tool to characterize metamorphic CM. A further advantage of the method is that it can be obtained on conventional petrographic thin sections, which is a non-destructive, in situ measurement; thus the textural relationship of the $\mathrm{CM}$ in the surrounding matrix can be checked. The thin section has a better heat removal because of the mineral matrix and it is 
possible to control the orientation of the $\mathrm{CM}$ with respect to the incident laser beam (Beyssac et al. 2002).

A Raman spectrum of CM is composed of first-order $\left(1100-1800 \mathrm{~cm}^{-1}\right)$ and secondorder (2500-3100 $\mathrm{cm}^{-1}$ ) regions (Tuinstra and Koenig 1970; Nemanich and Solin 1979). In the first-order region, at $1580 \mathrm{~cm}^{-1}$, the $\mathrm{G}$ band (as graphite band) occurs, and three additional bands (the so-called defect bands), D1 $\left(1350 \mathrm{~cm}^{-1}\right)$, D2 $\left(1620 \mathrm{~cm}^{-1}\right)$ and D3 $\left(1500 \mathrm{~cm}^{-1}\right)$ are directly related to the degree of structural disorder (e.g. Tuinstra and Koenig 1970). With increasing metamorphic grade the defect bands become narrower and decreasing, while the $G$ band becomes more intense. The second-order region is characterized by two further bands, S1 $\left(2700 \mathrm{~cm}^{-1}\right)$ and S2 $\left(2900 \mathrm{~cm}^{-1}\right)$; they also disappear gradually with increasing metamorphic grade.

Each spectrum can be characterized with the peak intensity ratio $(\mathrm{R} 1=\mathrm{D} 1 / \mathrm{G})$ and the peak area ratio $(\mathrm{R} 2=\mathrm{D} 1 /(\mathrm{G}+\mathrm{D} 1+\mathrm{D} 2)$. The more ordered the graphite the lower value of $\mathrm{R} 2$ it is characterized by. Beyssac et al. (2002) described an empirical equation to estimate the peak metamorphic temperature on the basis of the parameters of Raman spectra of metamorphic CM:

$$
\mathrm{T}\left({ }^{\circ} \mathrm{C}\right)=-445(\mathrm{R} 2)+641 .
$$

The peak temperature can be determined to $\pm 50{ }^{\circ} \mathrm{C}$ (due to the uncertainty of the calibration), within the range of $330-650{ }^{\circ} \mathrm{C}$. Rahl et al. (2005) modified the thermometer, applicable from 100 up to $700{ }^{\circ} \mathrm{C}$ so that:

$$
\mathrm{T}\left({ }^{\circ} \mathrm{C}\right)=737.3+320.9(\mathrm{R} 1)-1067(\mathrm{R} 2)-80.638(\mathrm{R} 1)^{2}
$$

Aoya et al. (2010) re-calibrated the geothermometer of Beyssac et al. (2002) for regional metamorphism, and found that the co-variation between $\mathrm{R} 2$ and $T$ can be described by the following quadratic equation:

$$
\mathrm{T}\left({ }^{\circ} \mathrm{C}\right)=91.4(\mathrm{R} 2) 2-556.3(\mathrm{R} 2)+676.3 .
$$

On the basis of abundant measurements (Wiederkehr et al. 2011) the methods of Beyssac et al. (2002) and of Rahl et al. (2005) provide similar temperature estimates, with discrepancies of less than $30{ }^{\circ} \mathrm{C}$. Wiederkehr et al. (2011) recognized that the relative uncertainties in temperatures derived using the calibration of Rahl et al. (2005) are higher when compared to results using those of Beyssac et al. (2002), especially at temperatures above $480{ }^{\circ} \mathrm{C}$. A discussion of calibration possibilities at lower temperatures $\left(\sim 200-300{ }^{\circ} \mathrm{C}\right)$ is given in Lahfid et al. (2010).

The measurements were carried out on oriented (perpendicular to the foliation) thin sections with a THERMO DXR Raman microscope, at the Department of Mineralogy, 
Geochemistry and Petrology, University of Szeged, with green laser source (532 nm laser, Nd-YAG). The laser passed through an optical microscope (Olympus BX41); for measurement the $100 \times$ lens was used in confocal mode. Irradiation power at the sample surface was $5 \mathrm{~mW}$. The spectra were measured by high resolution grating with spectral window of $50-1861 \mathrm{~cm}^{-1}$, with a CCD detector. A minimum of 10 independent points were analyzed on each sample and the data were collected at $20 \times 10 \mathrm{~s}$ length, with quadratic fluorescent correction (following the suggestions of Beyssac et al. 2002 and of Rahl et al. 2005).

The peak position, band area and band weight (FWHM) were determined using the Peak Fit 4.12 computer program with Voight-functions (combined Gaussian and Lorentzian profiles) after Beyssac et al. (2003).

\subsection{Sutured quartz grains as a deformation-related thermometer}

In metamorphic and igneous rocks complex interfingering (sutures) may occur along the monomineralic quartz-quartz grain boundaries. In numerous naturally deformed rocks Masuda and Fujimura (1981) and Hirth and Tullis (1992) studied the relationship between temperature, strain rate and the grain-boundary geometry, and found that the length of the suture segment increases with decreasing temperature. Kruhl and Nega (1996) established on natural samples derived from different metamorphic grades (low-greenschist to mediumgranulite facies) that the sutured quartz grain boundaries are statistically selfsimilar and so can be represented as fractal-like objects. On the calibrated geothermometer a linear function is suggested between the fractal dimension of the sutured quartz grain boundaries and the formation temperature. Kruhl and Nega (1996) also suggest that the result of the thermometer does not depend on the strain rate. This textural thermometer was refined by Takahashi et al. (1998) using artificial samples. The result of the thermometer is valid for an approximately $100{ }^{\circ} \mathrm{C}$ temperature interval. Among many others, Majumder and Mamtani (2009) successfully used the thermometer on deformed granite samples to determine the tectonic relationship and deformation history of the given rock unit.

For measurements of grain boundaries normal microscopic thin sections $(30 \mu \mathrm{m})$ with identical magnification $(\times 10)$ were evaluated. The sutured grain boundaries were digitized manually. The fractal dimension values (D) were obtained by Benoit 1.0 fractal geometry software using the divider method (Mandelbrot 1967) following the suggestions of Kruhl and 
Nega (1996). The slope of the regression line fitted onto the middle section of the log-log transformed L-r diagram defines D for each individual suture.

\section{Petrography}

\subsection{Orthogneiss}

Slightly foliated, coarse-grained, biotite-dominated gneiss is representative for the KIHA-NE Field (Fig. II.2/a). The principal phases are K-feldspar, plagioclase, quartz and two micas; the accessories are apatite and zircon, which usually occur as idiomorphic grains.

In all studied samples feldspar predominates over quartz (Fig. II.2/b). The grains are not deformed; they are commonly sericitized and altered to carbonate and an undetermined set of clay minerals. Several feldspar grains contain quartz inclusions forming a myrmekitic microtexture. The second main rock-forming mineral, quartz, shows marks of moderate ductile deformation exhibiting subgrains and slightly serrated grain boundaries. Biotite and muscovite coexist in the samples with a clear dominance of biotite which determines the foliation planes of the samples at macroscopic scale (Fig. II:2/b). The large biotite flakes are reddish brown, usually fresh, although in some cases slightly chloritized. Chlorite commonly forms pseudomorphs after single amphibole grains as well. These grains have a greenishcolourless pleochroism and bright blue, locally yellowish interference colour. Small, secondary opaque and carbonate minerals are present in them as inclusions.

The fractures of the gneiss samples are usually narrow; they contain carbonate infill and in some cases have a few cm-wide altered zone around them (Fig. II.2/a), where biotite is replaced by chlorite, while feldspar is sericitized.

\subsection{Amphibolite}

Only a few samples represent this rock type; all of them show slightly oriented (nematoblastic) texture. Samples are strongly altered (Fig. II:2/c); the chloritized amphibole grains with carbonate patches are resorbed and not oriented. The sericitized plagioclase feldspar grains form polysynthetic twins. Accessories are zircon, apatite, magnetite and ilmenite. Narrow quartz veins cut the fine-grained, dark greenish samples. 

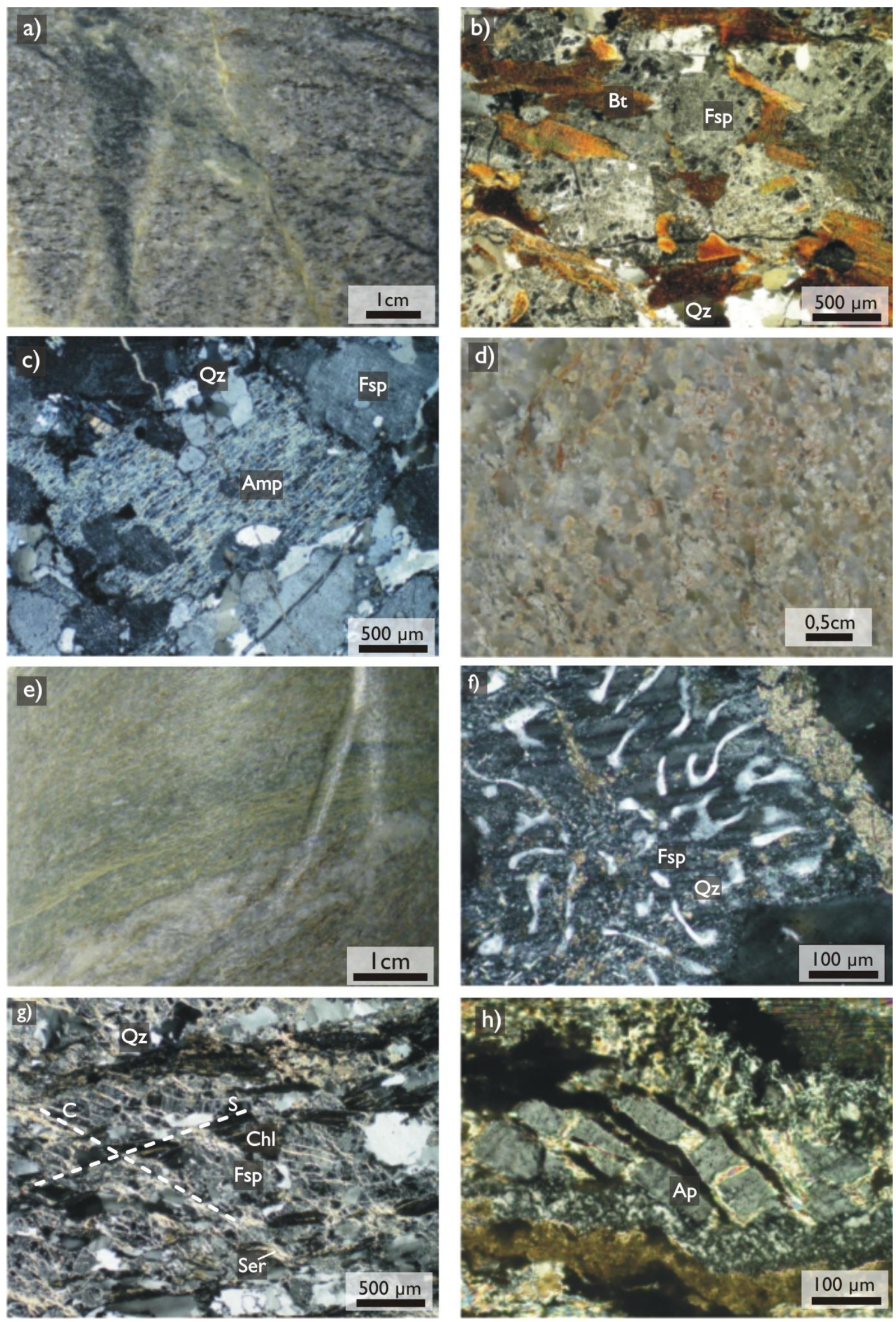

Fig. II: $2 a-h>$ 

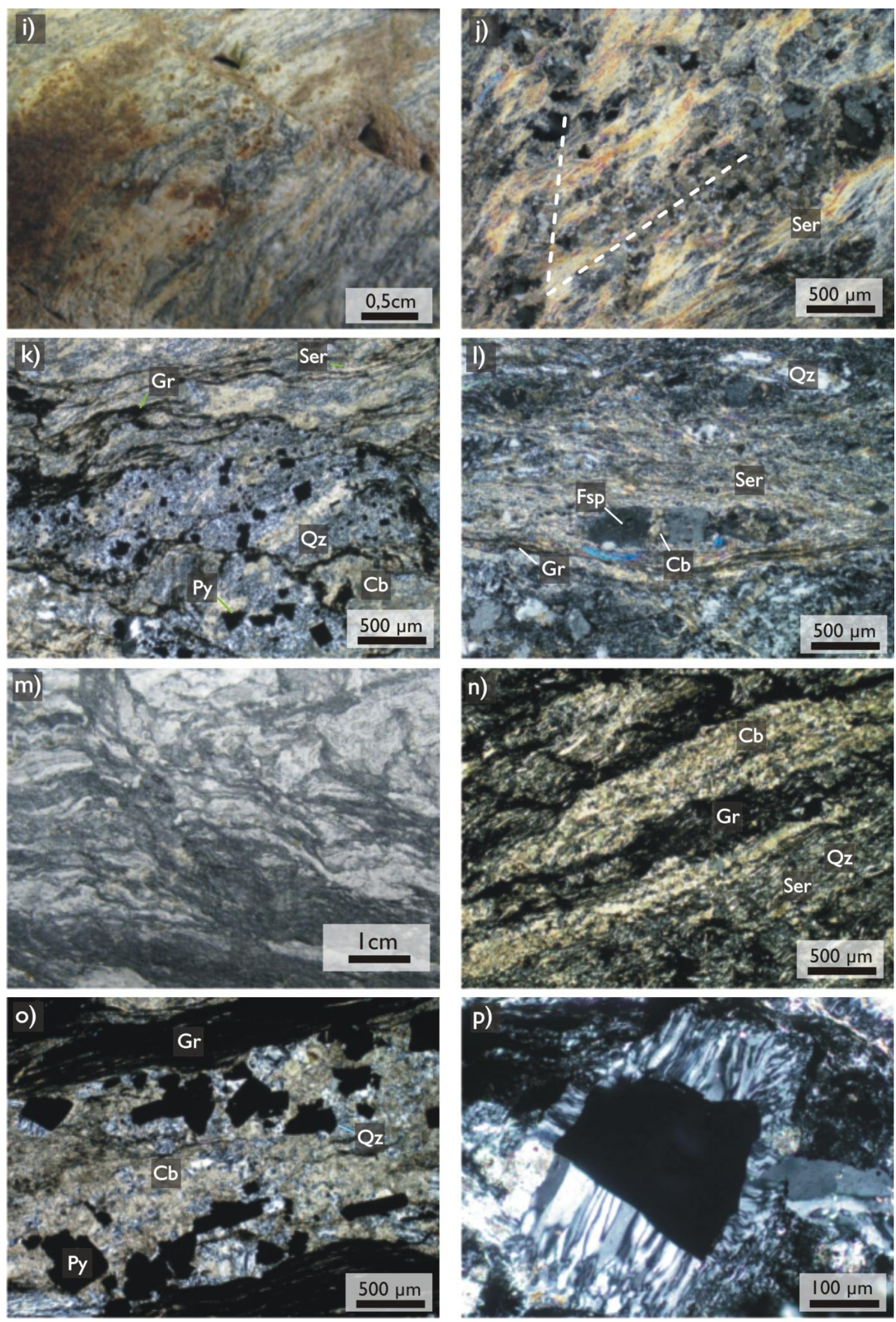

Fig. II. $2 i-p>>$ 
Fig. II.2. Rock types of the KIHA-NE Field.

a) macroscopic appearance of the typical orthogneiss; b) biotite flakes defining orientation in the feldspar and quartz-dominated matrix $(+N)$; c) texture of the altered amphibolite xenolith $(+N) ; d)$ macroscopic appearance of the mica-poor granite; e) macroscopic appearance of the orthogneiss mylonite; f) common myrmekitic feldspar suggesting igneous origin $(+N) ; g) C / S$ fabric in orthogneiss mylonite $(+N)$; $h$ ) bookshelf-textured apatite in the orthogneiss mylonite $(+N) .(2010)$. i) macroscopic appearance of the graphitic gneiss mylonite; j) C/S fabric in graphitic gneiss mylonite $(+N) ; k)$ narrow graphite stripes and small pyrite cubes in the quartz-sericite-carbonate matrix $(+N)$; $l$ ) feldspar boudinage in the graphitic gneiss mylonite $(+N) ; m)$ macroscopic appearance of the graphitic carbonate phyllite; $n$ ) wide graphite stripes in carbonatequartz- sericite matrix $(+N)$; $o$ ) pyrite cubes with quartz fringe in carbonate matrix $(+N)$; $p)$ pressure fringe around a pyrite grain in the graphite carbonate phyllite $(+N)$. Mineral abbreviations after Whitney and Evans (2010)

\subsection{Mica-poor granite}

The few coarse-grained granite samples exhibit equigranular texture with only moderate deformation but without any visible orientation (Fig. II.2/d). These samples are of rather simple mineralogy consisting mainly of quartz, K-feldspar with a little bit of muscovite.

\subsection{Orthogneiss mylonite}

The samples (Fig.II.2/e) are characterized by biotite and nearly equal amounts of feldspar and quartz with a texture similar to that of a typical orthogneiss (Fig. II.2/f). Accessories are rutile, apatite and zircon. In some cases the strongly sericitized feldspar grains are myrmekitic. The rock type exhibits mylonitic foliation (Fig. II.2/g); the S planes are formed by chlorite flakes after biotite, while the $\mathrm{C}$ planes show sericite bunches in the $\mathrm{C} / \mathrm{S}$ fabric. Feldspar deformed in a brittle manner, forming microboudinage with formation of sericite, clay and carbonate minerals in the necks of the structure. Quartz grains in the samples show evidence of ductile deformation with strongly serrate grain boundaries, undulose extinction and presence of deformation lamellae. Biotite is almost entirely replaced by chlorite. The chlorite flakes with deep purple interference colour often show kink band deformation and undulose extinction. White mica flakes are folded and locally form mica fishes. Carbonate minerals are common in the matrix as a secondary mineral. Apatite shows clear evidence of microfaulting presenting bookshelf structure (Fig. II.2/h).

The mylonite samples are significantly more fractured than the common orthogneiss is. Nevertheless, usually there is no metasomatized zone along the veins; they are mainly filled with carbonate minerals locally enclosing fragments of the adjacent rock. 


\subsection{Graphitic gneiss mylonite}

Texturally this lithology is a fine-grained mylonite characterized by a well developed C/S fabric (Fig. II.2/j). Unlike with orthogneiss mylonite, in this case graphite defines the $\mathrm{S}$ planes; sericite packets are typical along the $\mathrm{C}$ planes. There is no biotite in these samples; the role of feldspar is subordinate, while quartz is essential. Graphite and sulfide minerals (mainly pyrite) are present in significant amounts.

Feldspar is altered to sericite. Carbonate minerals and the few larger porphyroclasts are fractured and exhibit microboudinage fabric (Fig. II.2/l). Quartz commonly appears as monocrystalline ribbons and shows the same markers of ductile deformation as in the orthogneiss mylonite. Sericite, the most frequent mica phase, is present in fine-grained aggregates and locally a form folded bunches. It coexists with graphite stripes in interfingering texture that sporadically also contain larger muscovite flakes. Graphite usually appears in narrow bands of various widths that play a remarkable role in determination of the foliation. Pyrite grains appear both in single crystals and in large aggregates; no other sulfide minerals have been determined. In some cases they are mantled by a narrow pressure fringe of quartz (Fig. 2/k). Accessories are zircon, rutile and apatite. The latter often takes on bookshelf structure similar to that observed in the orthogneiss mylonite.

Carbonate minerals are essential matrix constituents. Due to their common dissolution, cavities of a few $\mathrm{cm}$ in size are frequently present in the samples. A few cores are completely brecciated and highly fractured. Veins are mainly filled by carbonate with a moderate amount of quartz. Most samples in cavities, breccias zones as well as along the numerous fractures are oil-spotted (Fig. II.2/i).

\subsection{Graphitic carbonate phyllite}

These samples distinctively consist of chaotically folded bands of fine-grained black and white material (Fig. II.2/m). The dark bands are characterized by graphite with some sericite and tiny muscovite flakes. Unlike with the graphitic gneiss mylonite, graphite is an essential rock-forming phase (Fig. II.2/n). Graphite is present in massive, thick bands interfingering with a small amount of white mica. Carbonate minerals and a subordinate amount of quartz form the white bands. Pyrite, the only sulfide mineral, is ubiquitous in this lithology (Fig. II.2/o). Their grains appear in varying size from sub-millimeter up to around half a centimeter, forming single idiomorphic crystals as well as aggregates. Individual 
crystals are usually surrounded by fringes of quartz and a small amount of carbonate (Fig. II.2/p). The pressure fringes are face-controlled and usually deformed (Passchier and Trouw 2005). Samples of this rock unit are fractured; the main vein filling mineral is carbonate with rare quartz.

\section{Results of Raman spectrometry}

Representative spectra for each measured rock unit are shown in Fig. II.3. The characteristic spectra of the graphitic carbonate phyllite and the graphitic gneiss mylonite samples are significantly different. The intensity of D1 of graphitic carbonate phyllite is slightly higher than that of the G band, while in the graphitic gneiss mylonite D1, the band is less intense than the $\mathrm{G}$ band. Furthermore, the $\mathrm{G}$ band of the mylonite is much narrower than that of the phyllite. The $\mathrm{G}$ band in both cases composes a prominent shoulder (D2) on the G band. Numerical results of the Raman spectral analyses are summarized in Table 1, based on 10-13 spectra in each studied sample. The sample heterogeneity in the graphitic carbonate phyllite lithology was found to be generally small, with the average standard deviation on R2 of 0.03 . The results for graphitic gneiss mylonite have a greater average standard deviation (0.1). Plotting the results on a histogram (Fig. II.4), skewness can be observed toward the smaller R2 values.

The results of the carbonaceous material thermometry are presented in Table II.1. The average difference between the result of Equation 1 (Beyssac et al. 2002) and Equation 2 (Rahl et al. 2005) is about $25{ }^{\circ} \mathrm{C}$. The temperature values for the graphitic carbonate phyllite $(\mathrm{n}=60)$ with the different calibrations are $368.1 \pm 15{ }^{\circ} \mathrm{C}$ (Beyssac et al. 2002), $384.2 \pm 38{ }^{\circ} \mathrm{C}$ (Rahl et al. 2005) and $369.8 \pm 15^{\circ} \mathrm{C}$ (Aoya et al. 2010), while for the graphitic gneiss mylonite $(\mathrm{n}=55)$ they are higher, being $411.9 \pm 45^{\circ} \mathrm{C}$ (Beyssac et al. 2002), $387.5 \pm 35^{\circ} \mathrm{C}$ (Rahl et al. 2005) and $415.6 \pm 47^{\circ} \mathrm{C}$ (Aoya et al. 2010). The Student's t-test, the statistical probe regularly used to compare means of independent populations, confirms that at a 0.01 significance level the estimated metamorphic peak temperatures for the two units are different. 


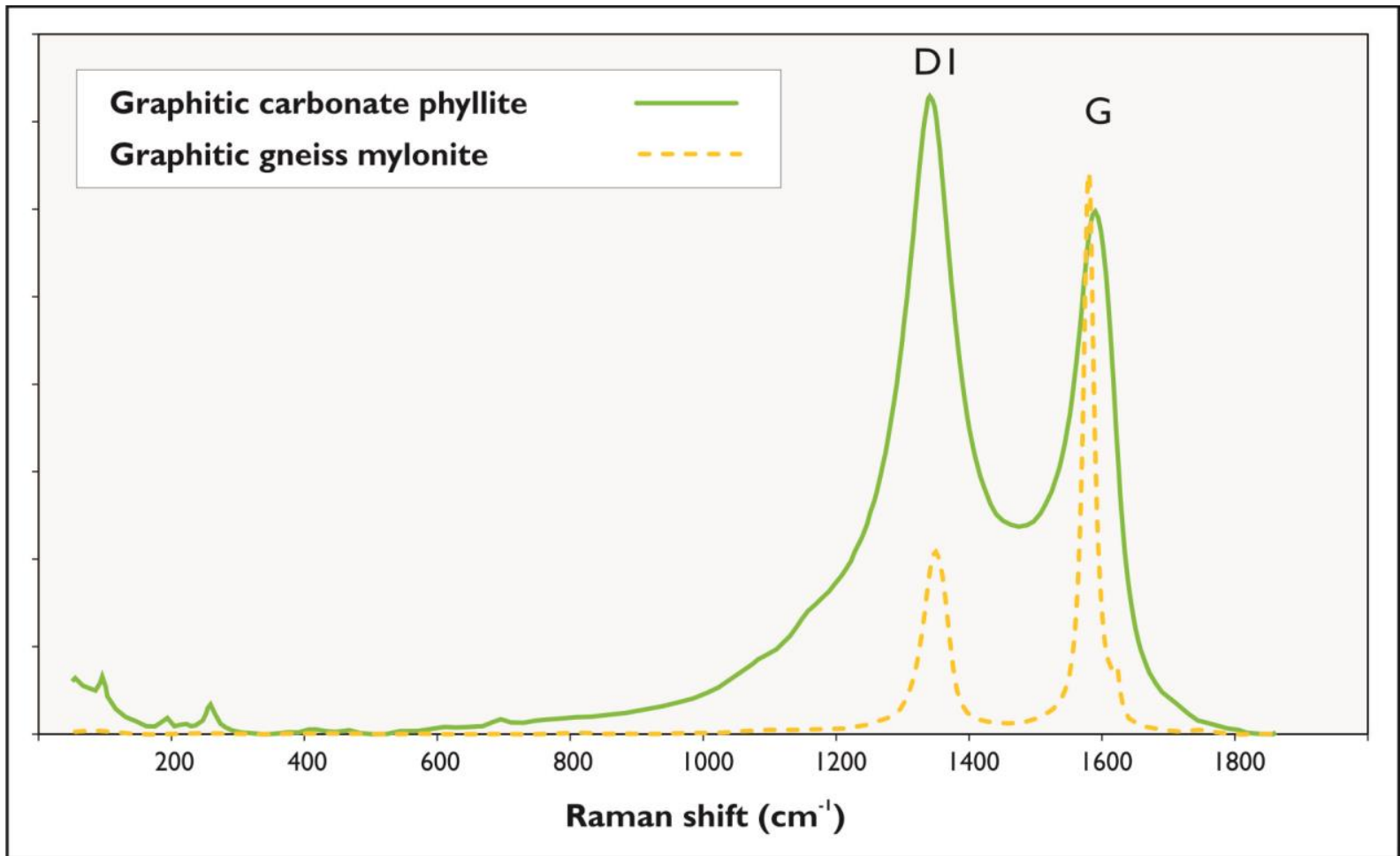

Fig. II.3. Typical examples of the first-order regions of the Raman spectra of the measured rock types following curve decomposition

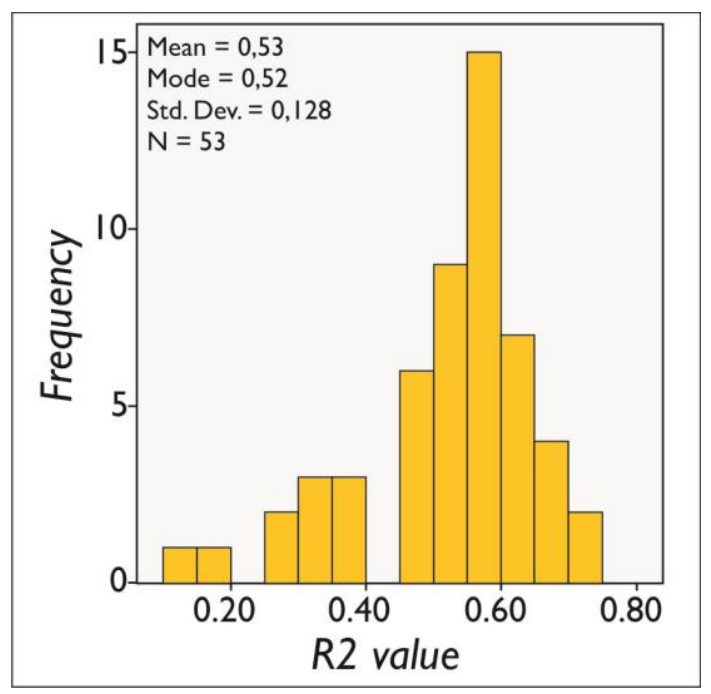

Fig. II.4. Distribution of $R 2$ values of graphitic gneiss mylonite

$($ Mean $=0.53$, Mode $=0.52$, Std. Dev. $=$ $0.13)$

Table II.1. Mean values and standard deviation (s) of the parameters (position, full width at half maximum FWHM) obtained from decomposition of Raman spectra of the measured samples

Lithotype: "C" Graphitic gneiss mylonite, "D" Graphitic carbonate phyllite; Temperatures: 1: Beyssac et al. (2002), 2: Rahl et al. (2005), 3: Aoya et al. (2010); R1=D1/G peak height ratio, R2: $D 1 /(G+D 1+D 2)$ peak area ratio 


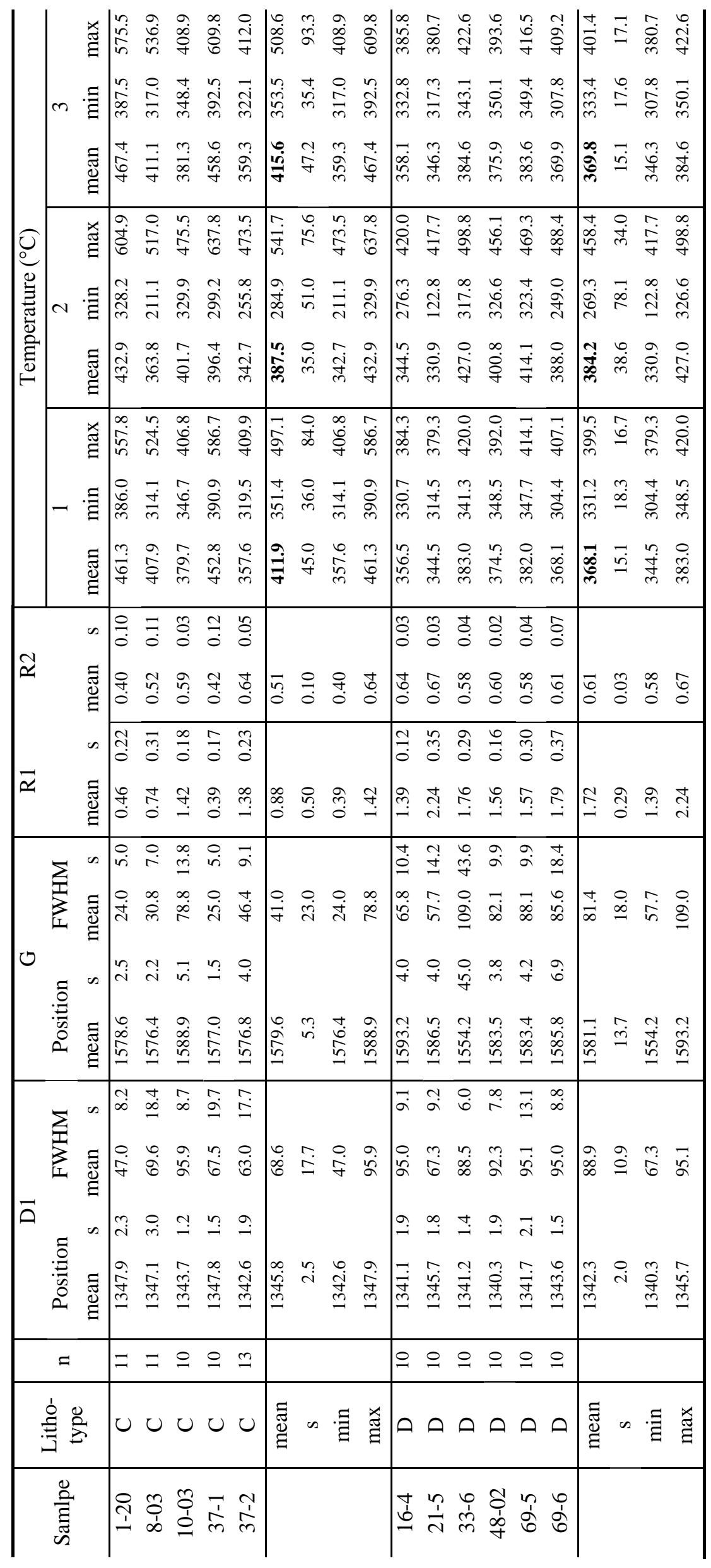




\section{Results of sutured quartz grains geothermometry}

This geothermometer was used in cases of the orthogneiss mylonite and the graphitic gneiss mylonite in order to provide information about temperature conditions of the ductile deformation event. The $\mathrm{D}$ value of the sutured quartz grain boundaries was found to be $1.21 \pm$ 0.02 (15 cases) in the orthogneiss mylonite samples, while in the graphitic gneiss mylonite samples $\mathrm{D}=1.23 \pm 0.05$ (5 cases) is typical. Using the calibration scheme of Kruhl and Nega (1996) deformation temperatures of $T_{d e f} \sim 470{ }^{\circ} \mathrm{C}$ can be estimated for the orthogneiss mylonite and $T_{d e f} \sim 440{ }^{\circ} \mathrm{C}$ for graphitic gneiss mylonite, respectively (Fig. II.5).

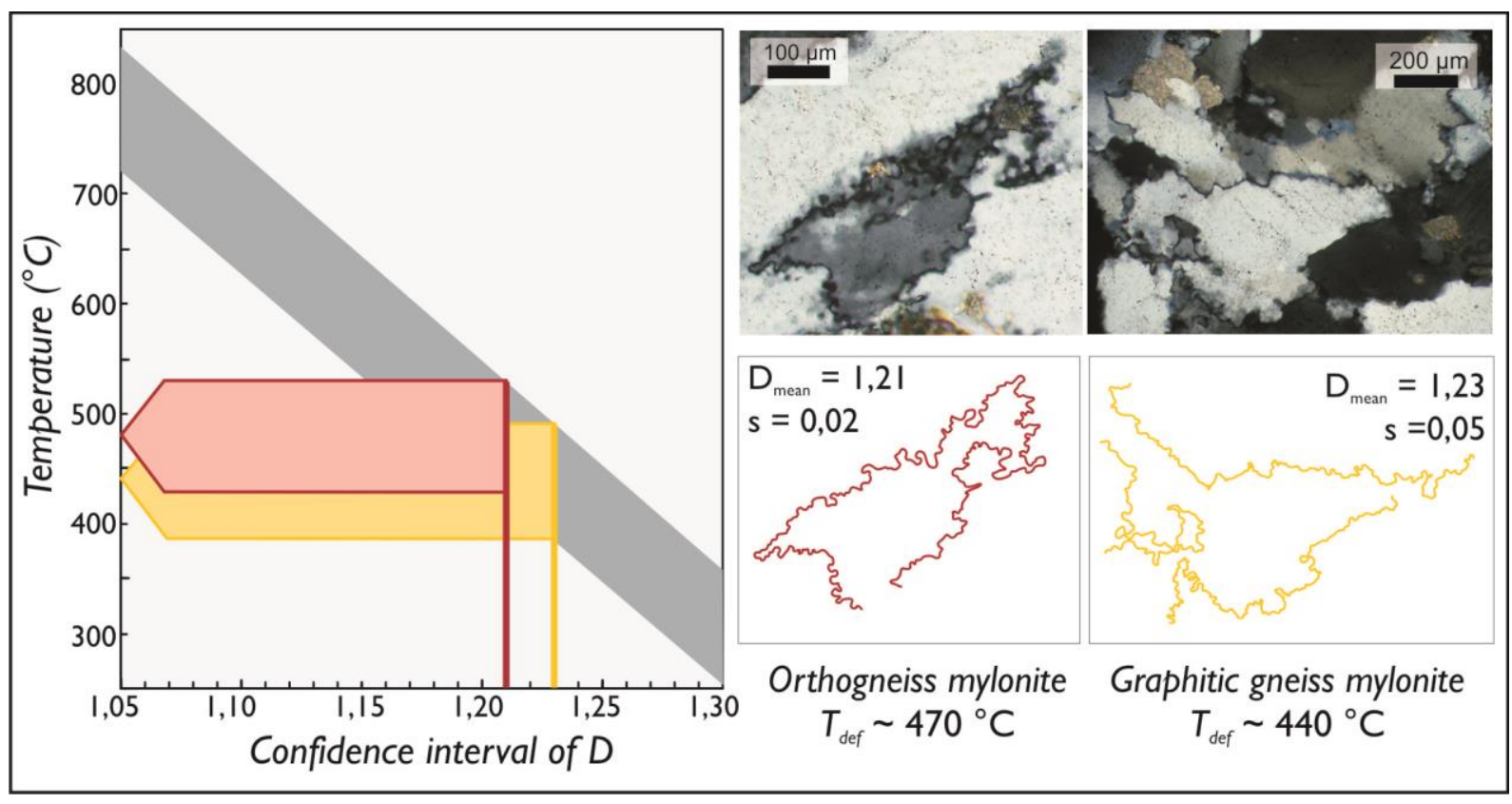

Fig. II.5. Estimation of the fractal dimension values $(D)$ of serrated grain boundaries measured on quartz grains from graphitic gneiss mylonite and gneiss mylonite, respectively.

Temperature data calculated using the method of Kruhl and Nega (1996)

\section{Discussion and conclusions}

\subsection{Interpretation of the results of Raman spectrometry and the CM thermometer}

Raman spectroscopy of the carbonaceous material thermometer is quite a new method for estimating the characteristic temperature for CM containing-rocks. Several factors that may influence the measurement and the temperature estimation were previously discussed in numerous papers. The most essential points are summarized here. Measurement on polished surfaces may cause an anomalously high D band. To avoid this effect measurement should be carried out beneath the surface, or on transparent adjacent grains (Beyssac et al. 2003). 
According to Beyssac et al. (2003) sample orientation may affect the Raman spectrum, especially in the case of well-crystallized graphite. Therefore it is worth measuring on thin sections oriented perpendicular to foliation. In this way the optical axis of the laser beam is set perpendicular to the mean $\mathrm{CM}$ axis.

Aoya et al. (2010) investigated the orientation effect in almost deformation-free contact metamorphosed and deformed regional metamorphosed samples. The measurements were carried out both perpendicular and parallel to the graphite $\mathrm{c}$ axis. The result in R2 values shows as little as 0.004 difference (Aoya et al. 2010: fig 9.), suggesting that the Raman spectroscopy method can be used as a CM thermometer regardless of the crystallographic orientation of CM. Furthermore, for samples nearly free of orientation, R2 values depend on the sample heterogeneity, if a sufficient number of measurements is carried out (Aoya et al. 2010).

The basic measurement parameters, acquisition time and magnification $(\times 50$ vs. $\times 100)$ have no significant effect on the temperature determination (Aoya et al. 2010). It is proved that if the wavelength $(514.5 \mathrm{~nm}$ vs. $532 \mathrm{~nm})$ and the laser energy increase, the D1 intensity decreases compared to that of G. Nevertheless this systematic difference is negligible in temperature estimation (Aoya et al. 2010).

Since the thermometer is based on the structural defects of the metamorphic CM, the effect of pressure or mechanical shearing must be discussed as well. According to Beyssac et al. (2004) mechanical shearing could be an important source of uncertainty, but based on their results this effect does not contribute more than a few ${ }^{\circ} \mathrm{C}$ uncertainty to the estimated temperature. Aoya et al. (2010) also studied the effect of high differential stress. They consider that the deformed metamorphic CM has higher R2 values because of a greater amount of crystal defects. According to Kwiecinska et al. (2010) pressure can have a distinct influence on the process of physical-structural graphitization. Nevertheless they emphasize the reliability of the thermometer calibrated by Beyssac et al. (2002).

Beyond these factors the CM has a natural heterogeneity (Wiederkehr et al. 2011), which may have an influence on the results of the measurement and temperature estimation. During deposition CM types of various organic precursors that underwent heterogeneous graphitization may mix (Wiederkehr et al. 2011; Rantitsch et al. 2004). Aoya et al. (2010) note that graphitization is a time-dependent process before attaining thermal equilibrium, resulting in larger R2 values of the CM. Heterogeneity may also appear within a single grain (Aoya et al. 2010). Nevertheless, standard parameters, mean and standard deviation usually provide reliable characteristics of the data distribution (Rantitsch et al. 2004); when applying 
the CM thermometer the average R2 value for the sample must be determined (Aoya et al. 2010). To obtain a reliable metamorphic temperature a substantial number of measurements should be made for each sample (Aoya et al. 2010).

Wiederkehr et al. (2011, fig. 9) compared Raman spectroscopy of CM-derived temperatures with literature data and established that these temperatures are consistently in coincidence with the peak temperature of the given rock unit. The authors studied in detail (2011, fig. 5) the relationship between the calibrations of Beyssac et al. (2002) and those of Rahl et al. (2005). In general the differences are within $\pm 50{ }^{\circ} \mathrm{C}$ uncertainty, while the relative errors of the temperature data computed by Rahl et al. (2005) are higher compared to Beyssac et al. (2002), especially for temperatures above $480{ }^{\circ} \mathrm{C}$.

In the measured KIHA-NE samples co-variation of temperature data estimated by the two calibration methods fits well to that observed by Wiederkehr et al. (2011). Temperatures estimated by Aoya et al. (2010) essentially overlap with those derived from Beyssac et al. (2002). In the case of the graphitic carbonate phyllite unit heterogeneity of the CM is quite small; average standard deviation for $\mathrm{R} 2$ value is as low as 0.03 . This may indicate a uniform CM which was formed at $T \sim 370 \pm 15^{\circ} \mathrm{C}$ peak temperature. The behavior of graphitic gneiss mylonite is just the opposite. Here R2 values show significantly larger average standard deviation (0.1). In addition, its distribution function (Fig. II.4) is asymmetric and exhibits a clear skewness towards smaller R2 values. If this high sample heterogeneity were caused by the above-mentioned factors, usually an increase of heterogeneity (deformation, imperfect graphitization), the data would shift toward the higher R2 values (smaller temperatures). That is why it is suggested that the above effects are not responsible for the observed heterogeneity. Instead, rock fragments of diverse metamorphic histories may have become juxtaposed in the mylonite zone. Although the most typical rock type is characterized by $T \sim$ $410{ }^{\circ} \mathrm{C}$, some pieces probably represent even higher temperatures. In the graphitic gneiss mylonite, Raman spectrometry data indicate mixing of rocks of different peak metamorphic conditions along the single time shear zone.

\subsection{Petrologic interpretation}

According to the results of the petrologic and thermometric study, the KIHA-NE Field consists of four main lithological units with incompatible structural and metamorphic evolutions. Each well that samples more lithologies suggests the same systematic spatial order for the four block along the ideal rock column, with orthogneiss, orthogneiss mylonite, 
graphitic gneiss mylonite and graphitic carbonate phyllite from the bottom to the top (Fig. II.6). The figure displays a summary of the thermometric results for the four units outlined above.

Gneiss samples in the lowermost structural position are similar in all mineralogical and textural characteristics to those described by Zachar and M. Tóth (2004) for the JH uplift. Based on the presence of relic myrmekite as well as euhedral habit of the accessory phases (zircon, apatite) the protolith of this gneiss variety is of igneous origin. Similarly to the JH area, the sporadic appearance of amphibole xenocrysts in the gneiss matrix is typical. There are only a few amphibolite samples available in the KIHA-NE area. They all appear within the orthogneiss-dominated interval, so even if amphibolite pieces do not exhibit a clear evidence for the contact with the gneiss, they should be xenoliths in the orthogneiss body similar to the adjacent JH dome (Zachar and M. Tóth 2004). The presence of the mica-poor granite specimens further strengthens the similarity between the two neighboring localities.

The gneiss mylonite samples have a very similar mineral assemblage and relic textural features to the lowermost orthogneiss body, suggesting that orthogneiss should have been the protolith of the gneiss mylonite and their evolution had to be identical prior to the last ductile deformation event. The typical deformation features, presence of mica fish, bookshelf texture, as well as microboudinage, all indicate mylonitic deformation in an extensional rather than compressive stress field (Passchier and Trouw 2005). According to the retrograde mineral assemblage (sericite, chlorite, carbonate minerals) the ductile deformation took place under low-grade conditions. The quantitative determination of the temperature of mylonitization gives $T_{\text {def }} \sim 470{ }^{\circ} \mathrm{C}$, with a significant but poorly estimated error due to the rough calibration method and the uncertainty of image analysis.

The graphitic gneiss mylonite, on the basis of its mineral composition, can clearly be separated from both the orthogneiss and the graphitic carbonate phyllite. Its undeformed protolith from the adjacent terrains of the basement is still unknown. The carbonaceous material thermometer allows estimating the peak metamorphic temperature of this rock type with $T \sim 410 \pm 45{ }^{\circ} \mathrm{C}$. The mylonitic deformation of this rock unit can be characterized by extensional textural features at $T_{\text {def }} \sim 440{ }^{\circ} \mathrm{C}$.

According to Árkai (1991) the graphitic carbonate phyllite probably had a marly protolith formed under euxinic facies conditions. Although the mineral assemblages of the two upper lithological units are similar, the evidently different Raman spectra of the carbonaceous materials of the graphitic carbonate phyllite and the graphitic gneiss mylonite samples prove their separate evolution. Furthermore, carbonaceous material is more 
homogeneous in the case of the graphitic carbonate phyllite unit resulting in temperature estimations of much lower peak temperature, with smaller uncertainty $\left(370 \pm 15^{\circ} \mathrm{C}\right)$.

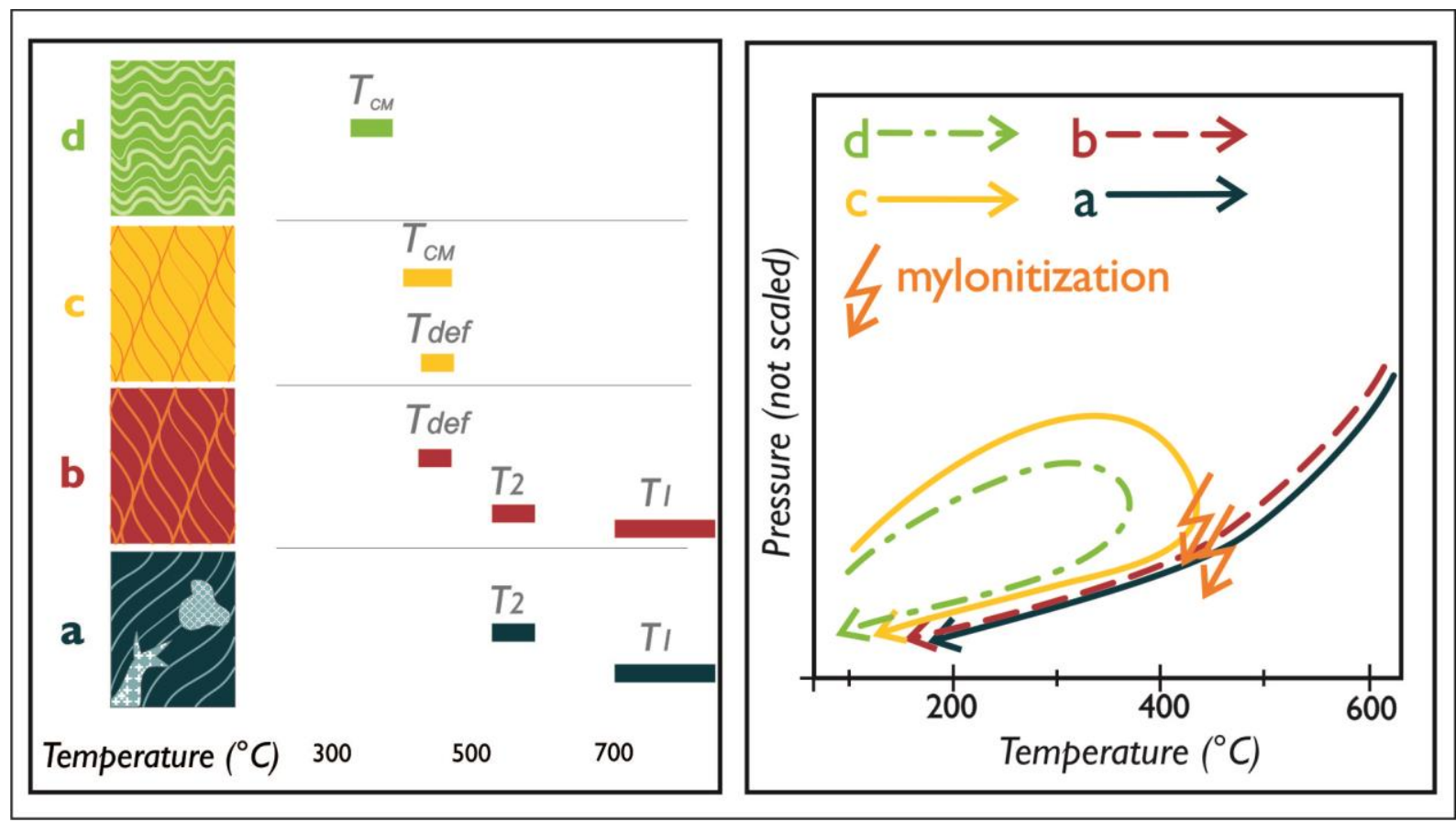

Fig. II.6. The ideal rock column for the KIHA-NE field with the characteristic temperature data for the metamorphic, structural evolutions of the subsequent rock units.

Legend: $a$ - orthogneiss; $b$ - orthogneiss mylonite; $c$ - graphitic gneiss mylonite; $d$ - graphitic carbonate phyllite; $T_{C M}$ - temperature of carbonaceous material thermometer by Raman microspectroscopy; $T_{\text {def }}$ - temperature of deformation by quartz suture thermometer; $T_{1}$ and $T_{2}-$ characteristic temperatures (Zachar and M. Tóth 2004)

\subsection{PTd evolution}

Core data from several wells suggest that at the deepest structural position of the ideal rock column orthogneiss is common in the KIHA-NE Field. Based on textural features this rock type might be identical to that described in detail by Zachar and M. Tóth (2004) and Zachar et al. (2007). The existence of a SW-NE extending orthogneiss zone in the southern part of the Pannonian Basin was already assumed by Szepesházy (1962) who found that the $\mathrm{JH}$ block is the westernmost part of this belt. Assuming the identical nature of the neighboring orthogneiss blocks, the metamorphic conditions of the JH gneiss $\left(T<580{ }^{\circ} \mathrm{C}\right.$; Zachar and $\mathrm{M}$. Tóth 2004) can be applied to the KIHA-NE block as well.

Although beside the orthogneiss samples, a highly mylonitized variety is also known from the KIHA-NE area, the transition between the two lithologies is not exposed. In the JH block only a few samples remind of the effect of the postmetamorphic greenschist facies 
mylonitization event (Zachar and M. Tóth 2004), without any information about the spatial context. A much better-represented situation is reported from the Szeghalom-N area (NE of the KIHA-NE Field) by Schubert and M. Tóth (2002). Here wells penetrated and sampled an almost $150 \mathrm{~m}$-thick shear zone from the undeformed orthogneiss down to the mylonitic core zone, proving continuous change. In spite of missing transitional rock types between orthogneiss and mylonite, a similar situation is assumed for the KIHA-NE area. In the Szeghalom-N Field a mylonitic deformation temperature of $T_{d e f} \sim 430{ }^{\circ} \mathrm{C}$ was calculated in the orthogneiss using the quartz suture thermometer (Jánosi et al. 2007). A rather similar value can be estimated for the KIHA-NE orthogneiss mylonite samples, suggesting comparable post-metamorphic evolution.

Although the metamorphic evolution of the next block upward along the KIHA-NE ideal rock column is essentially different, the mylonitic deformation temperature of graphitic gneiss mylonite is comparable to that calculated for the orthogneiss mylonite. These $T_{d e f}$ values are also coherent with the textural observation that in both sample groups feldspar deforms in a brittle way (Voll 1980).

The two uppermost lithological blocks consist of similar, but slightly different mineralogical compositions. Calculated metamorphic peak temperatures are also different, but have a slight overlap.

All thermometry data together suggest that the present lithological section exposed in the upper few hundred meters of the KIHA-NE area does not represent an undisturbed piece of the original Variscan lithosphere. Instead, the total thickness of the missing portion is significant. In fact, between the top and the bottom of the ideal rock column there is about 200 ${ }^{\circ} \mathrm{C}$ peak metamorphic temperature deviation. Depending on the local thermal gradient this may mean even reach 5-10 km total difference in formation depth. The metamorphic peak temperature of the graphitic carbonate phyllite is the lowest; it must represent the shallowest portion of the one-time lithosphere. After a several hundred meter-thick hiatus the undeformed variety of graphitic gneiss mylonite follows downward. The position of the orthogneiss block in the original metamorphic column was several $\mathrm{km}$ deeper. This picture necessarily implies the presence of post-metamorphic tectonic boundaries between the subsequent lithological units.

Taking the uncertainty of the applied thermometry methods into account, the estimations of peak metamorphic temperature and that calculated for deformation overlap significantly, suggesting mylonitization occurred close to the deepest point of the metamorphic evolution of the graphitic gneiss mylonite. Furthermore, this value is identical to 
that calculated for mylonitization of the orthogneiss block. So, both the textural features implying deformation in extensional regime and the estimated temperatures $\left(\sim 455^{\circ} \mathrm{C}\right)$, are rather similar for the two mylonitic lithologies. This suggests that although physical conditions of the peak metamorphism were significantly different, the last deformation events of the two bodies are in close relationship. The two contrasting metamorphic blocks became juxtaposed along an extensional fault zone in the basement at approximately $15 \mathrm{~km}$ depth (Fig. II.7). We assume that the same event may have been responsible for transportation of the graphitic carbonate phyllite on top of the graphitic gneiss unit. As a result of the large-scale motion several $\mathrm{km}$ of material has disappeared due to tectonic erosion.

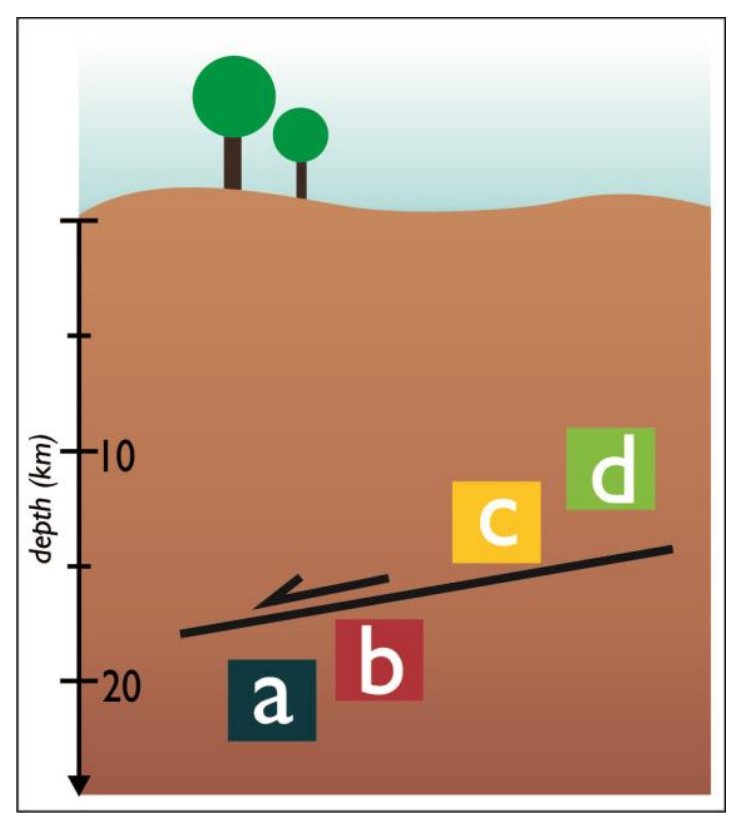

Fig. II.7. A hypothetical outline sketched for the development of the current rock bodies along the mylonitic shear zone

The appearance of blocks of contrasting metamorphic evolution in a relatively small region is not uncommon in the basement of the Pannonian Basin. A similar situation has previously been inferred in the Mezősas-Furta, Szeghalom and Dorozsma areas (M. Tóth and Zachar 2006; Schubert and M. Tóth 2002; M. Tóth and Zachar 2002; M. Tóth et al. 2002). The age of this tectonic event, essential for a significant part of the metamorphic basement, is still unknown. Following mylonitization the entire basement block was consolidated, uplifted and probably exhumed to the surface, as is indicated by surface weathering of the graphitic carbonate phyllite, proved by Árkai (1991). 


\title{
ChAPTER III.
}

\section{INTEGRATED CORE STUDY OF A FRACTURED METAMORPHIC HC-RESERVOIR; Kiskunhalas-Ne, Pannonian Basin}

\author{
Ágnes Nagy \\ Department of Mineralogy Geochemistry and Petrology, \\ University of Szeged, Szeged, Hungary \\ agnes.nagy@geo.u-szeged.hu \\ Tivadar M. Tóth \\ Department of Mineralogy Geochemistry and Petrology, \\ University of Szeged, Szeged, Hungary \\ mtoth@geo.u-szeged.hu \\ Balázs Vásárhelyi \\ Department of Structural Engineering, Pollack Mihály Faculty of Engineering, \\ University of Pécs,Pécs, Hungary \\ e-mail: vasarhelyib@gmail.com \\ Tamás Földes \\ Institute of Diagnostic Imaging and Radiation Oncology, \\ Kaposvár University, Kaposvár, Hungary \\ e-mail: t.foldes@t-online.hu
}

Acta Geodaetica et Geophysica Hungarica

48/1, 53-75 (2013)

DOI 10.1007/s40328-012-0008-y 


\title{
Integrated core study of a fractured metamorphic HC-reservoir; \\ Kiskunhalas-NE, Pannonian Basin \\ by: Ágnes Nagy, Tivadar M. Tóth, Balázs Vásárhelyi, Tamás Földes
}

\begin{abstract}
The petrologic interpretation of the coexisting lithologies in the KIHA-NE metamorphic block suggests that two of the four rock units may have a significant role in the migration and/or storage of hydrocarbons. The strongly sheared mylonite samples exhibit remarkable fracture systems with clear evidence of one-time oil migration. In the course of the integrated core study, in addition to the petrological methods, 3D CT scans and destructive and nondestructive rock mechanical treatments were fulfilled on representative samples and evaluated. On the basis of the results we can state that the petrologically different rock types have remarkably different brittle behaviours. The orthognesis mylonite is characterised by moderate anisotropy and fracture tendency. However, the fractal dimension and cumulative fracture length values do not suggest the formation of complicated and connected fracture systems. High anisotropy and a large and possibly communicating fracture system characterise the graphitic gneiss mylonite, achieved by a much lower work investment than for any other rock type.
\end{abstract}

\section{Introduction}

The fracture system of hard rock bodies serves as migration pathways and/or storage for various fluids of industrial importance: hydrocarbons, geothermal and drinking water. A single crystalline basement block may be characterised by different rock types with different rheology parameters and structural evolutions and thus the capacity for brittle deformation may be extremely heterogeneous inside the complex. Consequently, blocks with significantly different kinds of fracture systems with diverse characteristics may evolve in the same reservoir. To understand the behaviour of these fluid reservoirs, knowledge of their petrology is necessary and in this regard well-core investigations are among the most important facets. Because of the small number of cores compared with the number of wells, it is important to obtain as much information as possible from each sample. For efficiency it is desirable to integrate the results of the various core examination approaches in a coherent system. The main subjects that should be addressed are: a complex petrographic analysis, microstructure analysis, rock mechanics and an evaluation of fracture patterns both of natural and provoked origin.

The Pannonian Basin is situated inside the Alpine-Carpathian-Dinaric orogenic belt. Its crystalline basement is extremely complex, both petrologically and structurally. As a consequence of the complicated subsidence history of the basin during the Neogene (e.g., Tari 
et al. 1992; Horváth 1995; Csontos and Nagymarosy 1998; Horváth et al. 2006) uplifted metamorphic basement highs also formed (e.g., Tari et al. 1992; M. Tóth and Zachar 2006; Zachar et al. 2007; M. Tóth et al. 2009). These blocks serve as excellent fractured reservoirs of hydrocarbon (e.g., M. Tóth et al. 2002, 2004; Schubert et al. 2007) and thermal water (e.g., Stegena et al. 1992) and make the understanding of this region especially important. The aim of the present study is to understand the lithologies and their reservoir properties of a basement fluid reservoir (example of KIHA-NE) using the method of an integrated core examination. The region of the Kiskunhalas-NE (KIHA-NE) basement high is one of the most remarkable fractured metamorphic HC-reservoirs in the Pannonian Basin.

\section{Geological background}

The Pannonian Basin is a complicated mosaic of blocks with incompatible evolutions, because of its complex, multistage tectonic history (D. Lörincz 1996). The basement is composed mainly of Variscan age crystalline rocks (Szederkényi 1984; Lelkes-Felvári et al. 2003; Lelkes-Felvári and Frank 2006). It underwent large scale extension during the early Jurassic (Csontos et al. 1992; Haas and Péró 2004) and nappe formation in the Cretaceous (Tari et al. 1999). During the Neogene basin subsidence, deep sub-basins evolved surrounded by basement highs. The metamorphic basement of the Pannonian Basin can be investigated by several borecores, which penetrated these uplifted regions.

The Kiskunhalas-NE Field is situated south of the Mid-Hungarian tectonic zone that separates the Tisza Unit from the ALCAPA Unit (Csontos and Nagymarosy 1998). According to recent interpretations, the study area is located close to the assumed front of the Codru Nappe, which formed due to Cretaceous tectonic activity. There are two neighbouring metamorphic domes that have been previously studied; the petrologically well-known metamorphic block Jánoshalma High $(\mathrm{JH})$ to the $\mathrm{SW}$ and the less well-known Tázlár $(\mathrm{T})$ to the NE (Fig. III.1).

According to the small number of papers that have previously dealt with the KIHA-NE Field: gneiss, micaschist, amphibolite, different mylonite types, migmatite and a lowgrade phyllite variety predominate in the study area with an unknown structural arrangement (Cserepes 1980; Cserepes-Meszéna 1986; T. Kovács and Kurucz 1984). T. Kovács (1973) suggests that in relation to the general amphibolite facies metamorphism of Variscan age, at certain places migmatites and diatexites formed. In the course of the following retrograde metamorphism, mylonite, chlorite schist and sericite schist evolved (Árkai 1991). Árkai 
$(1978,1991)$ suggests that the protolith of the phyllites was marly sediment formed under reductive conditions. Using illite crystallinity indices it is thought to have undergone a very low-grade metamorphism with a peak of about $270-300{ }^{\circ} \mathrm{C}$ (Árkai, in Cserepes-Meszéna 1986). Árkai (1991) supposes that the low-grade phyllite represents an exotic nappe and consequently its contact to other rock types must be tectonic. Geochemical data infer weathering of the phyllite body under surface conditions.

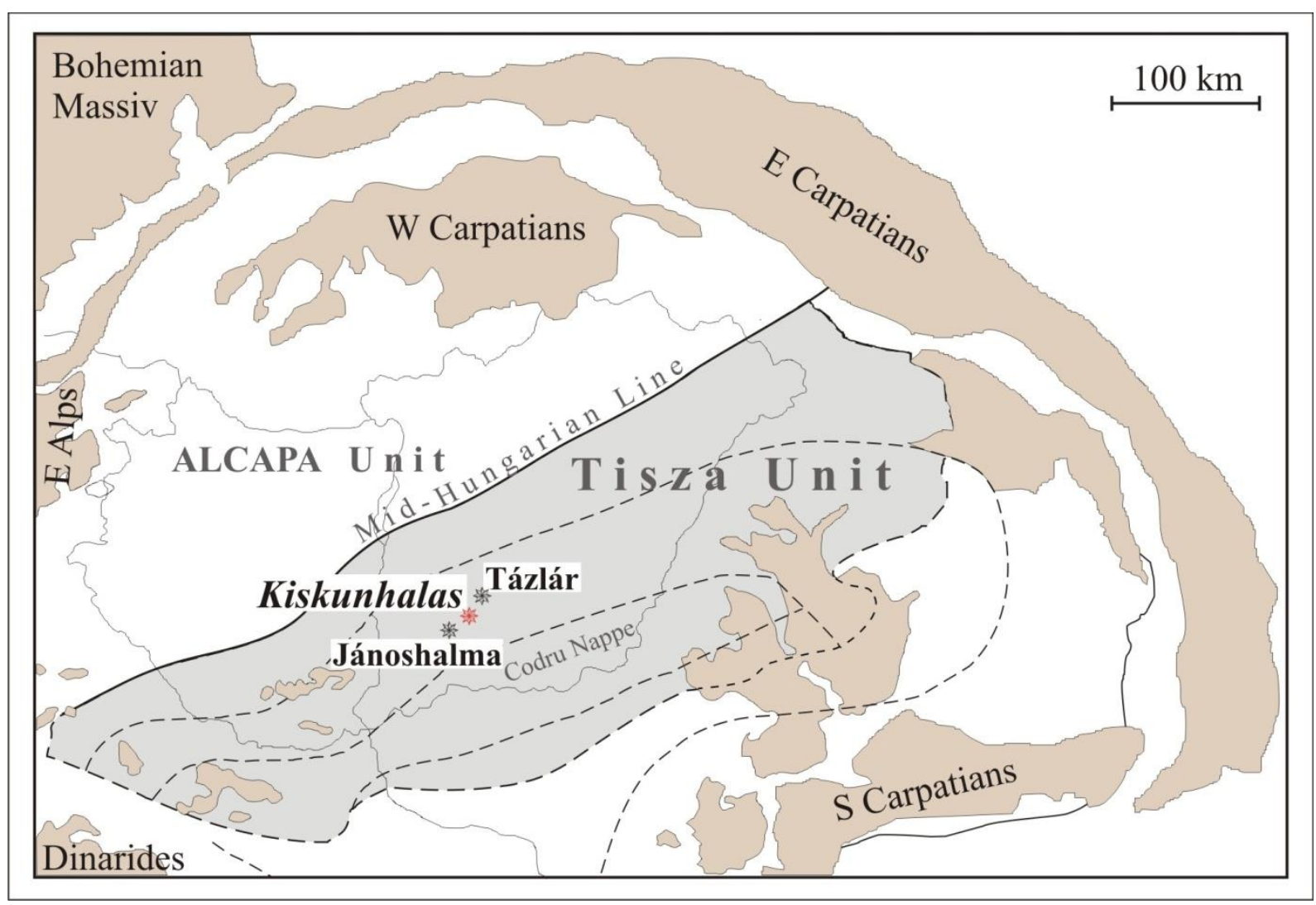

Fig. III.1. Simplified geological map of the Pannonian Basin in the Alpine-Carpathian-Dinaric system showing the position of the Kiskunhalas and the neighbouring fields. The dashed lines referred to the subunits of Tisza Unit

The latest examinations (Nagy and M. Tóth 2012) based on themacroscopic, microscopic and thermometric studies of borecore samples identified four main rock types. The ideal rock column was defined using all available borecore specimens. The following petrological characterisation is after Nagy and M. Tóth (2012). At the lowermost structural position an unaltered orthogneiss (OG) is characteristic (Fig. III.2/a). This gneiss variety contains amphibolites xenoliths and was intruded by mica-poor post-metamorphic granitoid intrusions. From the textural features and the mineral assemblage the orthogneiss is identical to that described in the neighbouring Jánoshalma high by Zachar and M. Tóth (2004). It exhibits a twostage evolution with very poorly constrained metamorphic conditions of $T_{1} \sim$ 
$700-850{ }^{\circ} \mathrm{C}$ at $P_{1}<0.65 \mathrm{GPa}$, and $T_{2}<580{ }^{\circ} \mathrm{C}$. From a geological reservoir point of view, this block has only minor significance because of the small amount of natural fractures. The next lithological zone upwards consists of orthogneiss mylonite (OGM) (Fig. III.2/b) exhibiting textural features of ductile deformation, which took place in an extensional regime (C/S fabric, apatite bookshelf, plastically deformed quartz grains). On the basis of the biotitemuscovite feldspar- quartz mineral assemblage and the relic magmatic textures, like mirmekitic feldspar grains and the idiomorphic habit of accessory phases (zircon), the protolith of the mylonite prior to ductile deformation should have been the lowermost orthogneiss. Some gneiss mylonite samples are locally oil spotted suggesting that the generally moderately fractured OGM zone may be important from a geological reservoir point of view. Further upwards, mylonites occur with extensional fabric elements (C/S fabric, apatite bookshelf, boudinaged clasts, deformed quartz grains) similar to those that characterise the OGM unit. This zone however, exhibits significantly different mineralogy. The diagnostic phases of the orthogneiss are missing (biotite) or play only a subordinate role (feldspar), while graphite, pyrite and carbonate become characteristic phases. According to the results of different thermometers that use Raman spectral parameters of carbonaceous material (Beyssac et al. 2002; Rahl et al. 2005; Aoya et al. 2010), the peak metamorphism of this graphitic gneiss mylonite zone (GGM) (Fig. III.2/c) was $T$ of $410 \pm 45^{\circ} \mathrm{C}$. The carbonate minerals occur in small-sized nests in the matrix, which locally could have been dissolved. Strongly fractured, locally brecciated borecore samples of this rock unit are often oil spotted. Estimations of the deformation temperature for both mylonitic rocks give approximately $T_{d e f}$ $\sim 455^{\circ} \mathrm{C}$ (using the quartz suture thermometer of Kruhl and Nega 1996). The uppermost member of the rock column is graphitic carbonate phyllite (Fig. III.2/d) represented by just a small number of samples. This rock unit can be characterised by $T$ of $370 \pm 15^{\circ} \mathrm{C}$, estimated by the Raman spectroscopy carbonaceous material thermometer. This rock type is not mylonitic.

Results of previous and current geothermometric calculations suggest that there is an approximately $200{ }^{\circ} \mathrm{C}$ difference between the peak metamorphic temperatures of the two extreme lithologies (orthogneiss and carbonate phyllite) in the rock column. This means a 5$10 \mathrm{~km}$ difference in formation depth depending on the one-time geothermal gradient. This result, together with presence of the extensional mylonites, implies that the study area evolved in an extensional stress regime following the thermal peak; blocks of different metamorphic conditions became juxtaposed along a shear zone at a depth corresponding to $\sim 455{ }^{\circ} \mathrm{C}$ (Nagy and M. Tóth 2012). The entire rock column behaved uniformly during the following tectonic 
development; at shallower positions it deformed in a brittle way. Nevertheless, the different lithology types not necessarily fractured in a same extent and mode.

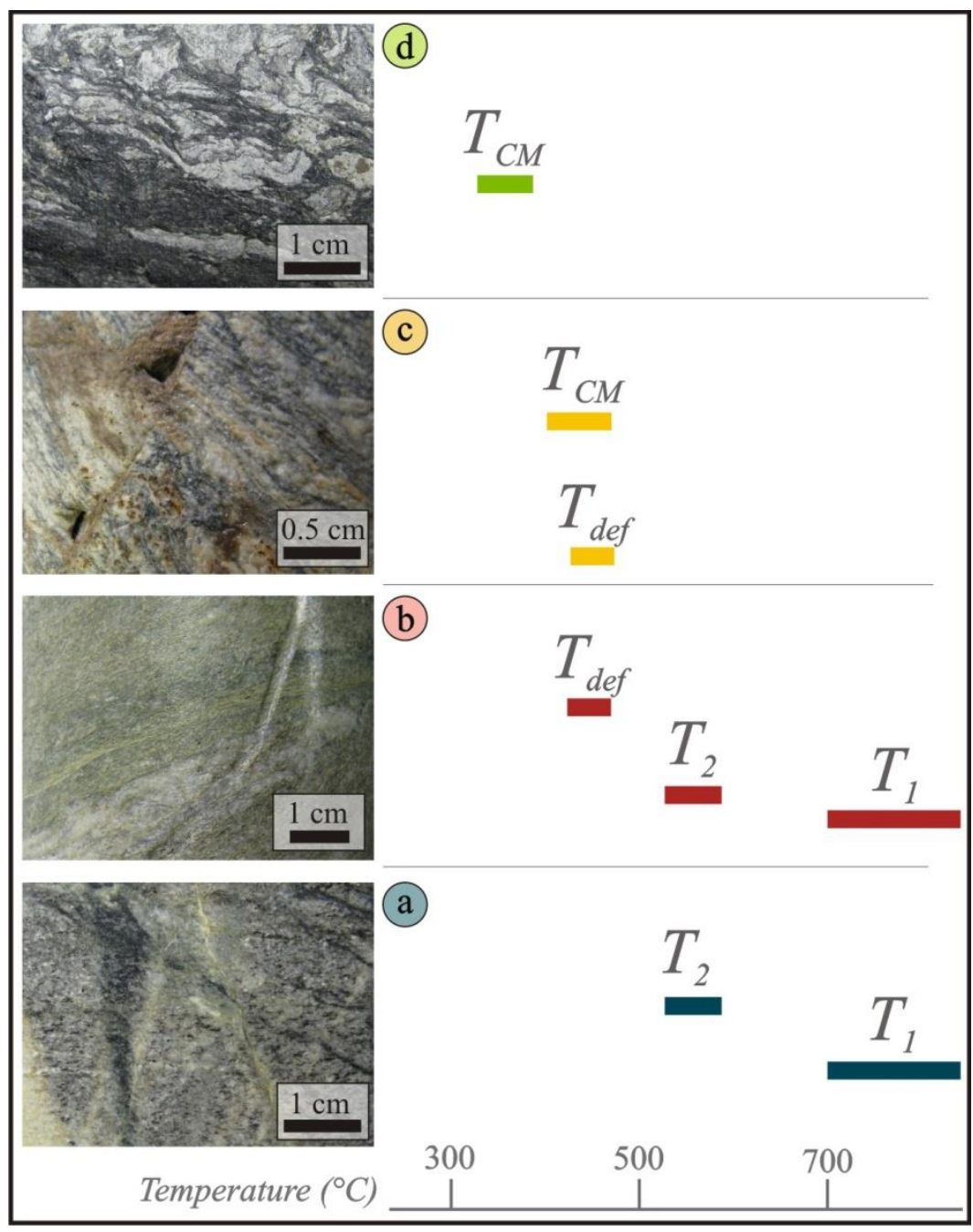

Fig.III. 2. The idealised rock column of KIHA-NE Field (after Nagy and M. Tóth 2012).

Representative macroscopic pictures of the lithologies and its characteristic temperatures: orthogneiss, (b) orthogneiss mylonite, (c) graphitic gneiss mylonite, (d) graphitic carbonate phyllite $T_{C M}$-temperature of carbonaceous material thermometer by Raman microspectroscopy; $\quad T_{\text {def }}$ temperature of deformation by quartz suture thermometer; $T_{1}$ and $T_{2}-$ characteristic temperatures (Zachar and M. Tóth 2004)

The petrologic interpretation of the coexisting lithologies in the KIHA-NE metamorphic blocks suggests that two of the four rock units may have a significant role in migration and/or storage of hydrocarbons. The strongly sheared mylonite samples exhibit remarkable fracture systems with clear evidence for one-time oil migration. In the course of the rock mechanical investigations we focus on these two mylonitic rock types.

\section{Methods}

In the course of the integrated core study, the following list of examinations was fulfilled and evaluated: 
(1) Identification and classification of the rock specimens by conventional petrographic and petrological methods; macroscopic and microscopic description, interpretation of the microtextures and geothermobarometric calculations. Using all these data the metamorphic and structural evolution of the investigated area can be sketched out and a reliable geological framework model can be established.

(2) Preparation of representative samples from the important lithologies with standardised circumstances for rock mechanical treatment. Careful selection of samples without fractures is essential, because even closed or cemented natural fractures may significantly modify the rock mechanical behaviour of the rock matrix.

(3) 3-dimensional scan of the specimens with Computed Tomography (CT) using standardised setup.

(4) Destructive and non-destructive rock mechanical treatment on the intact specimens.

(5) 3D CT scan of the treated specimens.

(6) Evaluation of rock mechanical data and the CT images using image analysis methods and statistical data processing.

Following several experiments (not detailed here) settings for all steps were optimised and the above list was used as a standard routine afterwards.

\subsection{X-ray computed tomography $(C T)$}

\subsubsection{Overview of the X-ray computed tomography}

$\mathrm{X}$-ray CT allows visualisation of the internal structure of objects by mapping the variation of the X-ray attenuation within the object. The resulting image displays the differences in density according to the X-ray attenuation law; the smaller the attenuation coefficient of the body, the darker the image. CT provides three-dimensional information about the heterogeneities within the samples in relation to the density and chemical composition of the object and the energy of the incident X-ray beam. This non-destructive method allows the detection of boundaries between phases and materials, or discontinuities (pores, fractures) of the samples. Furthermore, the data are digital, which aids easy quantitative analysis and the interpretation by image processing software (Ikeda et al. 2000; Ketcham and Carlson 2001; Mees et al. 2003). The radiological density is expressed in Hounsfield units (HU), which is a dimensionless number normalised by the linear attenuation coefficient of water $(H U=-1000$ for air, HU = 0 for water, Hounsfield 1973). 


\subsubsection{CT applications in geology}

CT was developed for medical applications and was later extended and widely-adopted in many industrial fields. The first geological application was inspired by the fact that CT could acquire interior information from irreplaceable specimens in a non-destructive manner. The early application and subsequent discovery of the further potential of CT is thoroughly discussed by Ketcham and Carlson (2001) and Mees et al. (2003).

Before the application of $\mathrm{CT}$, the most widely available examination of rock samples was in 2D. Although there were some circumstantial and time-consuming methods to get 3D information about the structural or textural features of a sample, like using successive digitised images acquired by serial thin sectioning or lapping (Bryon et al. 1995; Cooper and Hunter 1995; Marschallinger 1998), or by partial melting experiments (Philpotts et al. 1998), these were not applicable to all rock types (Ikeda et al. 2000). The propagation of the CT method in geology provided the opportunity for visualisation and quantitative textural analysis of igneous (e.g., Carlson et al. 2000; Ikeda et al. 2000) and metamorphic rocks (e.g., Denison et al. 1997; Denison and Carlson 1997; Ikeda et al. 2000; Ketcham 2005; Huddlestone-Holmes and Ketcham 2010).

In the case of conventional reservoir lithologies (sedimentary rocks), CT was used to determine the porosity of the rocks and investigate the fluid flow in the samples (e.g., Wellington and Vinegar 1987; Van Geet et al. 2000; Földes et al. 2004). In non-conventional (fractured hard rock) reservoirs, the porosity relates to the fracture properties of the rock, which can also be investigated by CT methods. A combination of breaking tests and CT scanning was applied by Raynaud et al. (1989) among others. They deformed and fractured four different rock types in a triaxial cell and then compared the experimental results with the radiological density data. Vinegar et al. (1991), in addition to strain localisation examinations on sandstone, observed the correlation between Hounsfield units and the porosity and grain density of each section of the samples. Be'suelle et al. (2003) also crushed the samples in a triaxial cell to investigate the strain localisation and then quantitatively characterised the damage state in thin sections. Other authors have examined faults in sandstone (Antonellini et al. 1994) or in granite (Kawakata et al. 1999) with CT.

This study aims to obtain images of the internal structure and the provoked fractures in the specimens on a millimetre scale and therefore, a conventional medical CT was the appropriate technique for scanning (Mees et al. 2003). The measurements were carried out on the S40 spiral Siemens Somatom Sensation CT scanner in the Institute of Diagnostic Imaging 
and Radiation Oncology, University of Kaposvár, Hungary. This is high-performance equipment with a dual-focus X-ray tube with rotating anode and Xe detectors. The voltage and current of the X-ray tube were $140 \mathrm{kV}$ and $189 \mathrm{~mA}$, respectively. The X-ray exposure time for each slice was $1.5 \mathrm{~s}$ and the thickness of each slice was $1 \mathrm{~mm}$. The voxel size was $0.25 \times 0.25 \times 1 \mathrm{~mm}$.

\subsection{CT data processing}

The HU values of the CT datasets are proportional to the density of the scanned object. These numerical data can be handled by statistical methods that give an opportunity to compare the density conditions of the intact and crushed samples. For this purpose we calculated the standard descriptive statistical parameters, mean, modus and standard deviation of the HU data, both for the whole 3D data blocks and for each slice independently, in order to understand the response of the different lithologies to stress. When evaluating the CT data only those parts of the images that related to the rock material were taken into consideration. Background (air) appears in the pixels of wider fractures in the crushed samples and was filtered out by choosing an appropriate threshold value. During the petrographic image analysis the Fiji (ImageJA 1.45i) software package was used.

To characterise quantitatively the ability for fracturing, a size-independent parameter should be defined. For this process CT images of the crushed samples were evaluated. The most straightforward way to measure the amount of fractures is to count pixels that contain provoked discontinuity. This value normalised by the area of the studied CT section results in a parameter called cumulative fracture length $(\mathrm{CFL})$. It is rather similar to the widely-used fracture intensity measured by $\mathrm{m} / \mathrm{m}^{2}$ (e.g., Liu et al. 2004; Ortega et al. 2006).

Nevertheless, explicit selection of those pixels that represent cracks in the CT image is rather difficult because of the wide spectrum of gray colours of the host rock itself. Therefore, the original data set should be treated with image analysis tools (brightness, contrast and intensity) to transform it to a black and white image, where one extreme (e.g. black) represents the fractures, whilst the other is for the rock material. For this process the Osiris 4.19 software was used.

The complexity of the fracture network can be characterised by numerous quantitative parameters, among which the fractal dimension of the pattern is a widely-used choice (e.g., Barton and Larsen 1985; Hirata 1989; Matsumoto et al. 1992; Tsuchiya and Nakatsuka 1995). In contrast to any other possible parameter, fractal dimension not only determines fracture density, but also the measure of scale independency of the network. Fractal dimension (D) 
values for each treated sample were determined by the common box-counting method (e.g., Barton 1995; Li et al. 2009) on representative CT sections parallel to the sample axis.

\subsection{Rock mechanical tests}

In the course of rock mechanical tests we investigated the mechanical behaviour of the fracture free rock body. Careful sample selection and the standardised laboratory measurements should provide a reliable sample set. Through the sample selection procedure we chose intact borecores, which were not affected by natural brittle deformation events. Following pre-selection using a hand lens and binocular microscopy and after appropriate internal structures had been tested by evaluating CT images, non-destructive and destructive rock mechanical methods were applied.

The aim in cutting samples was the creation of regular cylindrical shapes with the standard 2:1 (axis:diameter) size and $50 \mathrm{~mm}$ diameter. In a few cases, when borecore size did not allow cutting standard sized samples, rock mechanical data were converted using the suggestions of the ISRM (ISRM 2006). The American Society for Testing and Materials (ASTM) size effect corrections (ASTM 2004) were used for the compressive strength. When possible, more than one sample was taken from a single borecore. Considering the intensely deformed lithology, samples were prepared both parallel and perpendicular to the dominant foliation from the same lithologies. In total, 22 samples were prepared from the three basic lithologies representing 9 borecores from the KIHA-NE Field (Table III.1).

\subsubsection{Non-destructive tests}

After cutting the samples, their ultrasonic wave velocity was measured in accordance with the suggestion of the International Society for Rock Mechanics (ISRM 2006).

\subsubsection{Destructive tests}

The most common approach to study the mechanical properties of rocks is by using an unconfirmed compressive test. If the lateral surface of the rock is traction-free, the configuration is referred to as uniaxial compression $\left(\sigma_{1}>0, \sigma_{2}=\sigma_{3}=0\right)$. 


\begin{tabular}{|c|c|c|c|c|c|c|c|c|c|c|c|}
\hline $\begin{array}{c}\text { Samp. } \\
N r .\end{array}$ & Lit. & Or. & $\overline{C F 1}$ & $D$ & $\begin{array}{c}v_{U H} \\
(\mathrm{~km} / \mathrm{s})\end{array}$ & $\begin{array}{c}m . \sigma_{c} \\
(\text { Mpa })\end{array}$ & $\begin{array}{c}c . \sigma_{c} \\
(M p a)\end{array}$ & $\begin{array}{c}E \\
(G P a)\end{array}$ & $v$ & $E / \sigma_{c}$ & $W d$ \\
\hline II/1 & OG & PL & 11 & 1.46 & 44.90 & 42.4 & 56.8 & 9.58 & - & 169 & 0.337 \\
\hline VII/1 & OG & PP & 9 & 1.40 & 51.65 & 60.1 & 80.3 & 22.55 & 0.07 & 281 & 0.286 \\
\hline VIII/1 & OG & PP & 5 & 1.07 & 38.41 & 59.7 & 85.0 & 17.83 & 0.10 & 210 & 0.405 \\
\hline VIII/2 & OG & PP & 13 & 1.40 & 41.28 & 34.9 & 49.5 & 8.64 & 0.34 & 175 & 0.284 \\
\hline IV/1 & OGM & PL & 14 & 1.42 & 50.74 & 44.0 & 58.9 & 11.04 & 0.33 & 187 & 0.314 \\
\hline $\mathrm{IV} / 2$ & OGM & PL & 14 & 1.56 & 45.07 & 39.8 & 52.7 & 13.04 & - & 247 & 0.213 \\
\hline III/1 & OGM & PL & 9 & 1.50 & 44.48 & 41.9 & 55.8 & 12.00 & 0.12 & 215 & 0.259 \\
\hline III $/ 2$ & OGM & PL & 6 & 1.28 & 43.89 & 44.2 & 60.2 & 15.00 & 0.10 & 249 & 0.242 \\
\hline III/3 & OGM & PL & 8 & 1.24 & 42.11 & 65.3 & 88.2 & 16.70 & 0.03 & 189 & 0.466 \\
\hline IV/3 & OGM & PP & 7 & 1.35 & 40.90 & 41.6 & 55.7 & 8.56 & - & 154 & 0.362 \\
\hline IX/1 & OGM & PP & 6 & 1.31 & 50.08 & 71.5 & 100.0 & 34.50 & 0.12 & 345 & 0.290 \\
\hline VI/1 & GGM & PL & 13 & 1.53 & 46.60 & 37.0 & 49.1 & 15.40 & 0.00 & 314 & 0.157 \\
\hline $\mathrm{VI} / 3$ & GGM & PL & 21 & 1.67 & 44.87 & 20.3 & 26.9 & 6.14 & - & 228 & 0.118 \\
\hline $\mathrm{V} / 1$ & GGM & PL & 11 & 1.35 & 43.81 & 24.0 & 32.2 & 7.64 & 0.00 & 237 & 0.136 \\
\hline$V / 2$ & GGM & PL & 11 & 1.35 & 47.46 & 34.3 & 45.5 & 8.28 & 0.30 & 182 & 0.250 \\
\hline$V / 3$ & GGM & PL & 13 & 1.57 & 44.80 & 31.8 & 41.9 & 8.24 & 0.00 & 197 & 0.213 \\
\hline $\mathrm{X} / 1$ & GGM & PP & 7 & 1.39 & 60.23 & 17.8 & 24.2 & 12.60 & - & 521 & 0.046 \\
\hline$X / 2$ & GGM & PP & 7 & 1.41 & 36.93 & 71.8 & 97.2 & 13.30 & 0.02 & 137 & 0.710 \\
\hline$X / 3$ & GGM & PP & 6 & 1.32 & 53.95 & 53.3 & 71.1 & 14.52 & 0.10 & 204 & 0.348 \\
\hline$X / 4$ & GGM & PP & 6 & 1.50 & 42.67 & 32.1 & 41.5 & 10.30 & 0.28 & 248 & 0.167 \\
\hline $\mathrm{X} / 5$ & GGM & PP & 9 & 1.44 & 48.50 & 59.9 & 78.0 & 11.30 & 0.50 & 145 & 0.538 \\
\hline $\mathrm{VI} / 2$ & GGM & PP & 5 & 1.06 & 30.15 & 52.4 & 67.8 & 9.20 & 0.22 & 136 & 0.500 \\
\hline
\end{tabular}

Table III.1. Measured data of the samples

Samp. Nr.—sample number, Lit.—Lithology (OG-orthogneiss, OGM-orthogneiss mylonite, GGMgraphitic gneiss mylonite), Or-—orientation (PL-parallel, PP-perpendicular), CFL-cumulative fracture length, $D$-fractal dimension value, $v U H$-ultrasonic wave velocity, $m \sigma_{c}$-measured compressive strength, c $\sigma_{c}$-corrected compressive strength, E-Young's modulus, $v$-Poisson's ration, Wd-destruction work.

Using this configuration, the uniaxial strain $(\varepsilon)$ depends upon uniaxial stress $(\sigma)$ and can be measured. If $\sigma$ is plotted against $\varepsilon$ given the stress-strain curve, the point at which it reaches the maximum stress value is the uniaxial compressive strength $\left(\sigma_{\mathrm{c}}\right)[\mathrm{MPa}]$ and this point marks the transition from ductile to brittle behaviour. From the slope of a stressstrain curve at $50 \%$ of the ultimate stress, Young's modulus (elasticity modulus (E) [GPa]) can be experimentally determined; the elastic modulus is calculated at $50 \%$ of the ultimate strength, according to the ISRM (2006). This material property describes well the rigidity of the samples. The Poisson's rate value (v) is the ratio of the axial and lateral strains. Most rocks have Poisson's ratio values ranging between 0.2 and 0.4 . A perfectly incompressible material deforms elastically at small strains and would have a Poisson's ratio of exactly 0.5 (Jaeger et al. 2007). Due to the different rock samples and the uncertainty of the measuring methods, this material constant could be not determined absolutely (Gercek 2007). Destruction work (or 
strain energy - Wd ) can be calculated from the measured stress-strain curves. It is equal to the area under the measured curve and it is equal to the energy necessary for breaking the rock.

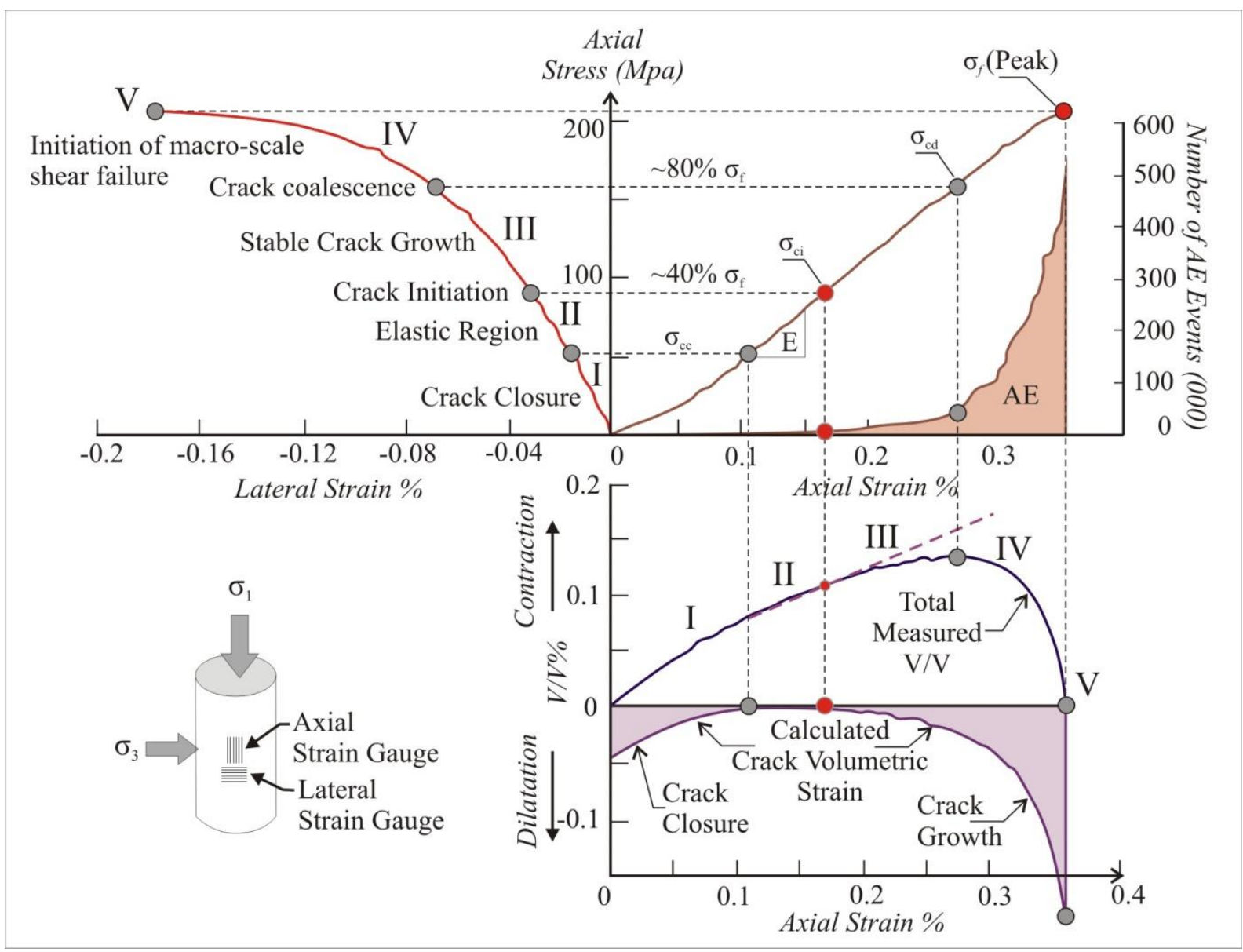

Fig. III.3. Stress-strain diagram of a rock showing the stages of crack development (after Martin 1993).

For the further explanation see the text.

Several characteristic stress levels can be determined through laboratory tests that are substantial in understanding the failure (damage) process of brittle rocks during compression. The complete axial stress-strain relations by Cai (2010) and Martin (1993) illustrated on Fig. III.3. The symbols are the following:

- $\sigma c c$ is the crack closure stress level,

- $\sigma \mathrm{ci}$ is the crack initiation stress level,

- $\sigma c d$ is called the crack propagation stress level. This latter parameter is close to the long-term rock strength (Martin 1993; Cai 2010).

The above three stress levels, i.e., $\sigma_{\mathrm{ci}}, \sigma_{\mathrm{cd}}$, and $\sigma_{\mathrm{cc}}$, show important stages in the macroscopic damage process of intact rocks. Crack initiation starts at stress levels of about 
$1 / 3$ to $2 / 3$ times the peak uniaxial load $\left(\sigma_{f}\right)$ for most brittle rocks (Bieniawski 1967; Cai et al. 2004).

The crack initiation stress $\left(\sigma_{\mathrm{ci}}\right)$ can be identified on intact rocks in the course of laboratory tests by the onset of stable crack growth or dilatancy. This can be defined from the stress-volumetric strain curve as the point of the departure of the volumetric strain observed at a given mean stress from that observed in uniform loading to the corresponding pressure (Bieniawski 1967). In the case of a uniaxial (or triaxial) test, the volumetric strain $\varepsilon_{\mathrm{v}}$ is defined by:

$$
\varepsilon_{v}=\varepsilon_{a}+2 \varepsilon_{l}
$$

where: $\varepsilon_{\mathrm{a}}$ and $\varepsilon_{\mathrm{l}}$ are the axial and lateral strains, respectively. The crack volumetric strain $\varepsilon \mathrm{cv}$ is defined by Martin (1993), so that:

$$
\varepsilon_{c v}=\varepsilon_{v}+\frac{1-2 v}{E} \sigma_{a}
$$

where: $\sigma_{\mathrm{a}}$ is the axial stress, $\mathrm{E}$ is the Young's modulus, and $v$ is Poisson's ratio. As the Fig. 3 illustrates, both the volumetric strain and the crack volumetric strain plots can be used to determine the crack initiation stress level $\left(\sigma_{\mathrm{ci}}\right)$. This parameter can also be identified as the point where the volumetric strain starts to differ from the straight line of the elastic deformation stage (stage II), or the crack volumetric strain deviates from zero, as shown in Fig. III.3.

Microscopic observations indicate that newly generated cracks are tensile in nature, generated by extension train, and mostly aligned in the same direction as the maximum compressive stress. After crack initiation, the propagation of the microcracks is a stable process, which means that the cracks only extend by limited amounts in response to given increments in stress (Cai 2010).

Unfortunately, we have no opportunity to measure the Acoustic Emission (AE), so the data were determined only the measured stress and strain parameters.

Destructive tests were carried out in the RockMechanics Laboratory at the Budapest University of Technology and the Economics. Under the experimental procedure the following conditions were used: periodic loading-unloading velocity, gradually grown amplitude and 3-4 loading cycles. The loading cycles were designed so that the samples were charged over the damage limit, but before fracturing, that is the hypothetic main fracturing zone. The following parameters were determined in the above detailed theoretical background: ultrasonic wave velocity, compressive strength, elastic (Young's) modulus, Poisson's ratio and destructive work. 


\subsection{Statistical methods for data processing}

In the course of the rock mechanical measurements and image analysis of CT scans, several numerical data were determined. This data set concludes the mechanical behaviour of the most essential rock types of the KIHA-NE Field. As reservoir properties in a hard rock reservoir are basically determined by fracture network characteristics, the question to be addressed by the statistical analysis of this data set, was whether or not known rock types behave differently concerning their rock mechanical parameters. To test how well they can be distinguished, discriminant function analysis is a suitable method. The calculations were performed in the computer program SPSS 18.

\section{Results}

\subsection{Results of CT measurements}

The size of the samples did not cause abnormal radiation absorption. CT images following rock mechanical treatment exhibit significantly different fracture patterns for the three studied lithologies and also sample orientation (Fig. III.4). For samples perpendicular to the foliation, markedly fewer fractures appear compared with parallel samples in all cases. Moreover, GGM tends to break more intensively than the two other rock varieties.

\subsection{Results of CT data processing}

For the quantitative comparison of the intact and crushed rock matrices, the HU of the CT images were used. The means and the modi of the whole scans and individual slices, as well as the HU histograms (Fig. III.5/a) of the samples were investigated.

The characteristic CT scan histograms of the samples are skewed, because the rock characteristic densities appear in the determined rock material interval. Therefore, the mean of the HU values are less useful than their mode. The intact samples cannot be separated by their HU distributions. They have quite similar shapes (Fig. III.5/a); narrow and nearly symmetric, while the modi of the histograms (Fig. III.5/b) are in same interval. The differences appear between the crushed and intact samples that belong to the same rock material. The histograms (Fig. III.5/a) of the crushed samples are shifted towards the higher HU values and are also 
more skewed in that direction. The box plots also suggest (Fig. III.5/b) that the largest difference is typical for the GGM samples. The diversity of OG samples is nevertheless rather uncertain because of the small sample number.

\section{Parallel to the foliation}

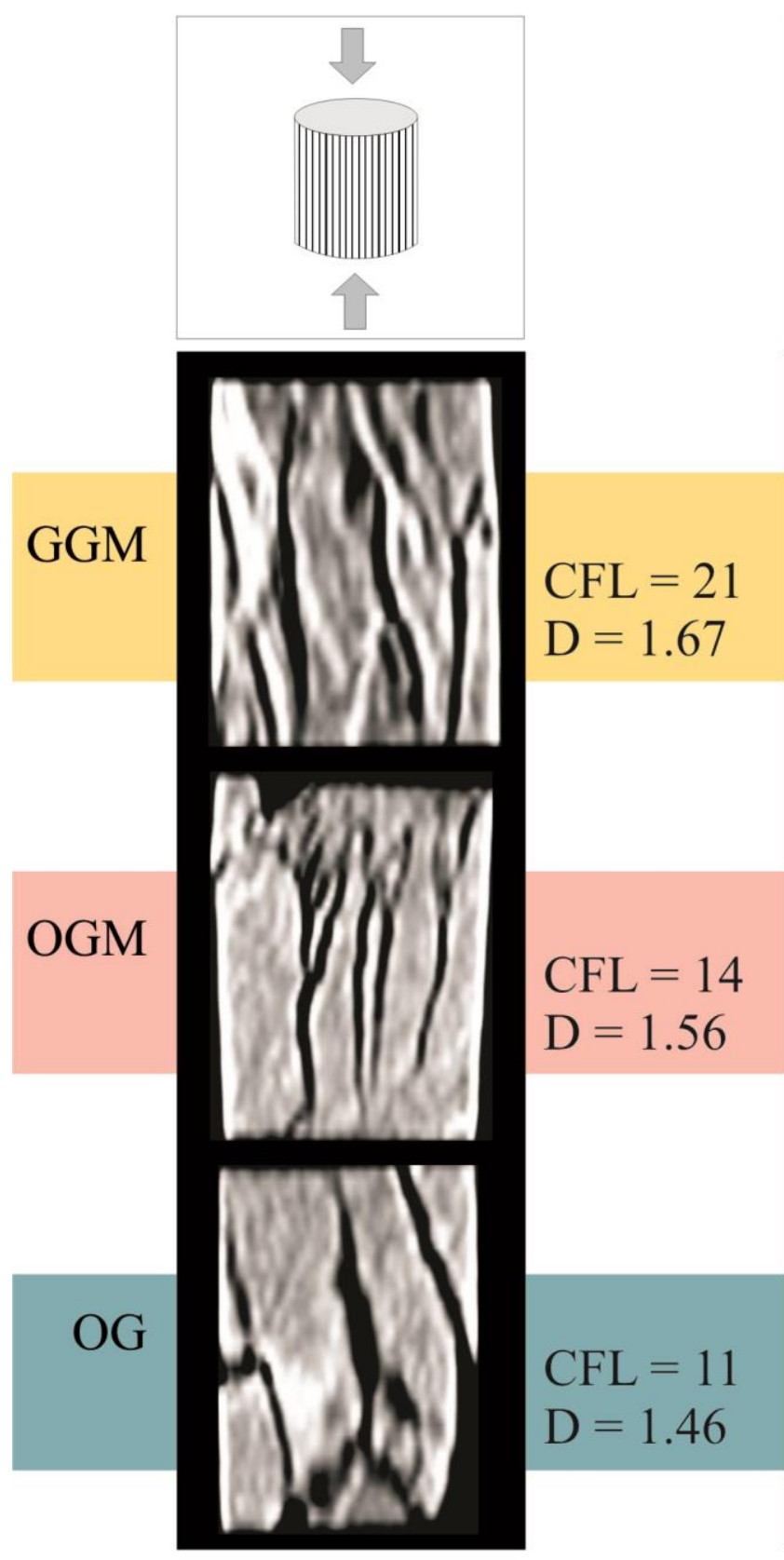

\section{Perpendicular to the foliation}
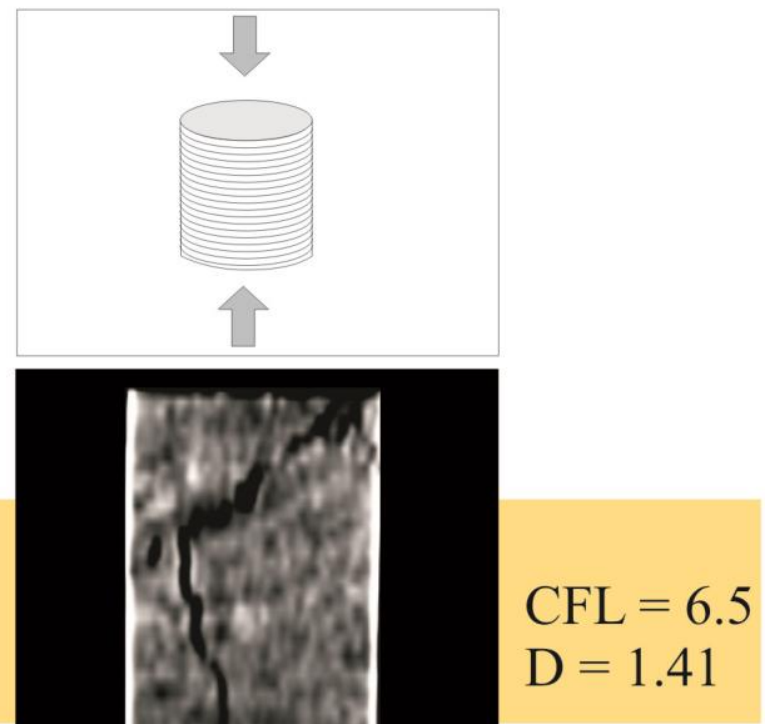

Fig.III.4. Characteristic CT scan section of the treated samples considering the sample orientation. The indicated CFL and D values are valid for the presented sample. The evolved fracture network is shown by black colour inside the samples.

Legend: OG-orthogneiss, OGM—orthogneiss mylonite, GGM-graphitic gneiss mylonite; FLcumulative fracture length, $D$-fractal dimension value

From the CT scans transformed to 1-bit images, the CFL and the D values of the fracture network were determined for each treated sample (Table III.1). The mylonite samples 
were cut perpendicular to the foliation and are characterised by similar CFL means $\left(\mathrm{OGM}_{\mathrm{pp}}=\right.$ $6.25, \mathrm{GGM}_{\mathrm{pp}}=6.62$ ); these are lower values than those typical for the parallel samples $\left(\mathrm{OGM}_{\mathrm{pl}}=10.2, \mathrm{GGM}_{\mathrm{pl}}=13.8\right)$. A similar tendency is shown for the fractal dimension values; the parallel GGM samples are in the higher interval of the D values. The two fracture network geometry parameters, CFL and D seem able to discriminate between the lithologies (Fig. III.5).

\subsection{Rock mechanical test results}

\subsubsection{Results of non-destructive test}

The results of ultrasonic wave velocity measurements are presented in the Table III.1.

\subsubsection{Results of destructive tests}

Using the standard unconfirmed compressive tests, the following parameters were determined: uniaxial compressive strength $\left(\sigma_{c}\right)$, elastic modulus (or Young's modulus) (E) and the Poisson's rate value (v) (Table III.1). In Fig. III.6, typical measured stress-stain curves are presented, which also show the elastic lines.

Generally the perpendicular samples have higher compressive strength values (meanpl $=51.1 \mathrm{MPa}$, meanpp $=66.9 \mathrm{MPa})($ Table III.1). Concerning the elastic modulus, the GGM lithology can be characterised by a large standard deviation, while its mean is the lowest. The Young's modulus of GGM is slightly lower $\left(\right.$ mean $\left._{\mathrm{pl}}=9.1 \mathrm{GPa}, \operatorname{mean}_{\mathrm{pp}}=11.87 \mathrm{GPa}\right)$ than the OGM samples $\left(\right.$ mean $\left._{\mathrm{pl}}=13.56 \mathrm{GPa}\right)$. In the case of GGM the specimens with parallel orientation are situated at the bottom of the range.

According to the commonly used rock engineering classification system, the rock material can be classified using the ratio of the elastic modulus and the compressive strength. Deere and Miller (1966) suggested a classification system presented in Fig. III.7. The KIHA NE samples exhibit a close to linear variation on this plot and they lie at the boundary of the low and average modulus ratio fields. Although the rock types appear mixed on the plot, all parallel GGM samples show significantly lower strength data than the other samples. 


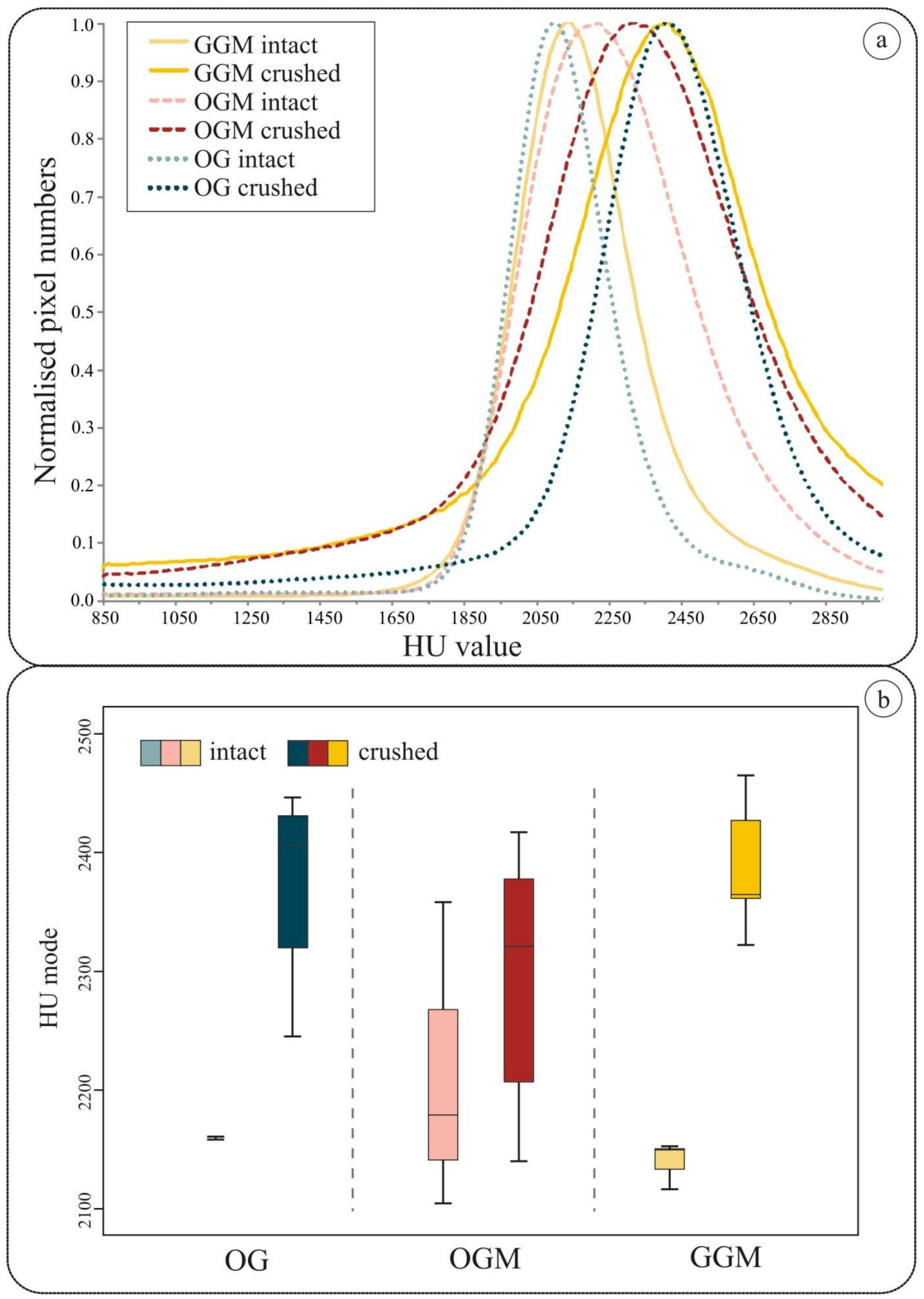

Fig. III.5. a) Characteristic histogram of the intact and crushed samples; b) boxplot of the mode values of the HU.

Legend: $O G$-orthogneiss, OGM-orthogneiss mylonite, GGM-graphitic gneiss mylonite; $P L-$ parallel with the foliation sample, $P P$-perpendicular to the foliation sample 
The Poisson's ratio values were also measured and calculated. However, the Poisson's ratio could not be measured for some samples (Table III.1). While the OGM results range in a well-defined interval (0.03-0.12 MPa), the GGM results vary in a rather wide range $(0.02$ $0.5 \mathrm{MPa}$ ). With respect to the orientation, the specimens cannot be separated.

The destruction work shows big differences depending both on the lithology and the sample orientation (Table III.1). Plotted with compressive strength data, samples exhibit a monotone, close to linear function (Fig. III.8/a). The parallel samples are presented in the lower interval of the parameters, while the GGM and especially the parallel GGM samples show the lowest values.

\subsubsection{Relationships between the rock mechanical and fracture network parameters}

Systematic evaluation of different parameters suggests that several of them are in tight relationship with each other. Fractal dimension of the fracture pattern decreases with increasing destruction work (Fig. III.8/b). The separation tendency of the parallel samples, especially the parallel GGM samples is evident on this plot. In these specimens, a dense fracture network with high $\mathrm{D}$ values evolved by low destruction work. The two geometric parameters of the fracture pattern, D and CFL, increase together (Fig. III.8/c). On the other hand with increasing Young's modulus, the CFL values show a slightly decreasing trend (Fig. III:8/d); the parallel GGM samples are shifted towards the region of a lower Young's modulus and higher CFL values.

\subsection{Results of statistical methods}

In order to determine those parameters that can be used to distinguish the a priori known petrological groups, discriminant function analyses were carried out.

In the first step of the analysis the two petrologically most different units, the OG with its mylonite (OGM) and GGM were investigated. The coinciding histogram (Fig. III.9/a) suggests that the two groups can clearly be separated using the discriminant score (DA):

$$
\mathrm{D}_{\mathrm{A}}=2.3 \mathrm{~W}_{\mathrm{d}}-2.8\left(\mathrm{E} / \sigma_{\mathrm{c}}\right)-\mathrm{CFL}+0.8 \mathrm{HU}+0.8 \mathrm{E}+0.7 \mathrm{D}
$$

where: $\mathrm{W}_{\mathrm{d}}$ is the destruction work, $\mathrm{E}$ is the Young's modulus, $\sigma_{\mathrm{c}}$ is the compressive strength, HU is the mode of the CT scan histogram, CFL is the cumulative fracture length and D is the fractal dimension of the fracture network. In the next step, the separation of OG and OGM on the basis of rock mechanical data was attempted. The results suggest that the two groups 
cannot be distinguished as they exhibit a unimodal histogram (Fig. III.9/b). The discriminant function in this case is:

$$
\mathrm{D}_{\mathrm{B}}=9.7 \mathrm{~W}_{\mathrm{d}}+10.4\left(\mathrm{E} / \sigma_{\mathrm{c}}\right)-12 \sigma_{\mathrm{c}}+1.3 \mathrm{E}-0.8 \mathrm{HU}+0.5 \mathrm{CFL}
$$

Finally, inside the GGM lithology the parallel samples were compared with those that were cut perpendicularly. The resulting plot (Fig. III.9/c) shows two distinct groups separated by scores calculated based on the discriminant function of:

$$
\mathrm{D}_{\mathrm{C}}=7.3 \mathrm{D}-8.5 \mathrm{CFL}-7.5 \mathrm{E}+5.6 \mathrm{HU}+5.2 v_{U H}+4.3 \sigma_{\mathrm{c}}
$$

where $v_{U H}$ is the ultrasonic wave velocity.

If all three groups (OG and OGM, GGM parallel, GGM perpendicular) are involved in the analysis simultaneously (Fig. III.9/d) they can be separated unambiguously using the discriminant functions:

$$
\begin{aligned}
& \text { Function } 1=6.3 \mathrm{~W}_{\mathrm{d}}-7.2 \sigma_{\mathrm{c}}-3.6 \mathrm{CFL}+2.3 \mathrm{E}+1.9 \mathrm{v}_{\mathrm{UH}}+1.4 \mathrm{D}+1.3 \mathrm{HU} \\
& \text { Function } 2=8.1 \mathrm{~W}_{\mathrm{d}}-7.7 \sigma_{\mathrm{c}}+5.4\left(\mathrm{E} / \sigma_{\mathrm{c}}\right)-1.5 \mathrm{D}+1.5 \mathrm{v}_{\mathrm{UH}} .
\end{aligned}
$$

\section{Discussion}

\subsection{The nature of the KIHA-NE reservoir rocks}

According to previous investigations (unpublished reports), the metamorphic basement of the KIHA-NE Field forms a heterogeneous fractured reservoir with oil-water phase boundaries at three different depths inside the rock body. Moreover, numerous neighbouring wells do not communicate with each other hydrodynamically, suggesting a highly compartmentalised fractured reservoir. The reservoir features are extremely heterogeneous throughout the rock body; in a $\mathrm{CH}$ productive interval the porosity is $2-20 \%$, whilst in a barren section it is $0 \%$. Nevertheless, a potential connection between the reservoir properties and lithological characteristics has never been previously studied. In the course of rock classification, we identified four blocks with different lithologies (Fig. III.2); the orthogneiss with amphibolites xenoliths and granite intrusions, the orthogneiss mylonite, the graphitic gneiss mylonite and the graphitic carbonate phyllite (Nagy and M. Tóth 2012). On the basis of macroscopic and microscopic descriptions, the intensity of natural fracturing as well as the presence of oil spots, suggests that the GGM and the OGM units may serve as the main migration pathways and as reservoir rocks. In the case of the GGM samples the cavities and dissolved carbonate nets seem to contribute to the enhancement of the reservoir properties. 


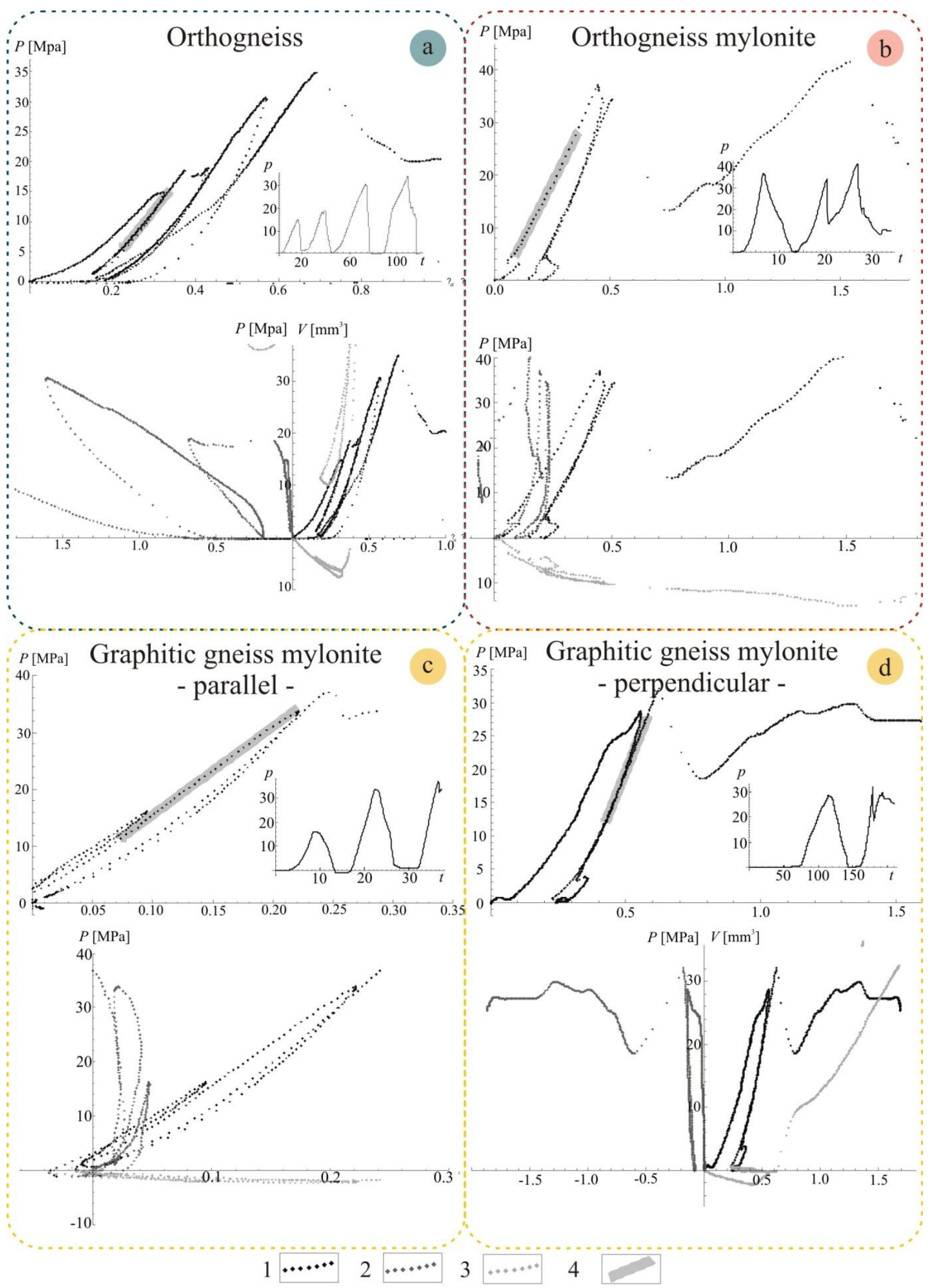

Fig. III.6. Characteristic stress-stain curves of: (a) orthogneiss, (b) orthogneiss mylonite, (c) graphitic gneiss mylonite parallel, (d) graphitic gneiss mylonite perpendicular.

Legend: (1-3) results of the measurements, (4) elastic line 
Ultrasonic wave velocity (Table III.1) and CT scan measurement (Fig. III.5) were carried out as non-destructive tests on the intact samples. The results do not show any significant differences between the lithologies; the measured values vary in narrow intervals in the case of each rock type, except for the HU values of the OGM samples; its wide range is probably caused by the mineralogical and microstructural heterogeneities of this lithology. Even slight variations in chemical composition of the protolith may cause remarkable differences in mica content, while different intensities of deformation may result in heterogeneous grain size reduction and various mineral alterations. Interaction of all these factors may have significantly modified rock density and thus the HU values measured by CT.

\subsection{The provoked fracturing of the rock types}

In the course of compression tests, an artificial fracture network was evolved in the rock samples. Cracks can be evolved in the rock body, when the local stress exceeds the local strength (Batzle et al. 1980). According to Gottschalk (1990) the stress concentration in the granitic and the mechanically similar gneissic rocks, has four main sources:

(1) presence of micropores, grainscale cavities and heterogeneities,

(2) pre-existing microcracks,

(3) elastic mismatches between constituent minerals, and

(4) slip and frictional sliding on favourably oriented phylosillicate cleavage planes.

The role of the preferred orientation of biotite grains in microcrack nucleation within the neighbouring phases is also emphasised (Gottschalk 1990; Seo et al. 2002). Batzle et al. (1980) also notes the role of the pre-existing microcrack and grainscale cavity orientation, which decides opening or closing as a function of the stress field.

The fracture network evolved in the course of the compression treatment could be visualised in $3 \mathrm{D}$ by $\mathrm{CT}$ scans. In evaluating the vertical and horizontal sections, remarkable differences concerning both lithology and orientation become conspicuous (Fig. III.4). Whilst in the samples perpendicular to the foliation just a few fractures evolved, whereas in the parallel samples numerous fractures were created. Mylonites, especially the GGM samples exhibit an even more dense fracture network than any other set of specimens. In addition to visualisation, numerical data derived from CT sections (cumulative fracture length (CFL), and the fractal dimension value (D) of the created fracture network) further confirm these differences (Table III.1); the parallel GGM samples are characterised by the highest CFL and 
D values. Further numerical data, the compressive strength, the Young's modulus, the Poisson ratio and the destruction work were provided by the compression tests (Table III.1). Although the number of the specimens was not sufficient to obtain statistically reliable data, the results do show the most important rock mechanical behaviour of the rock materials.

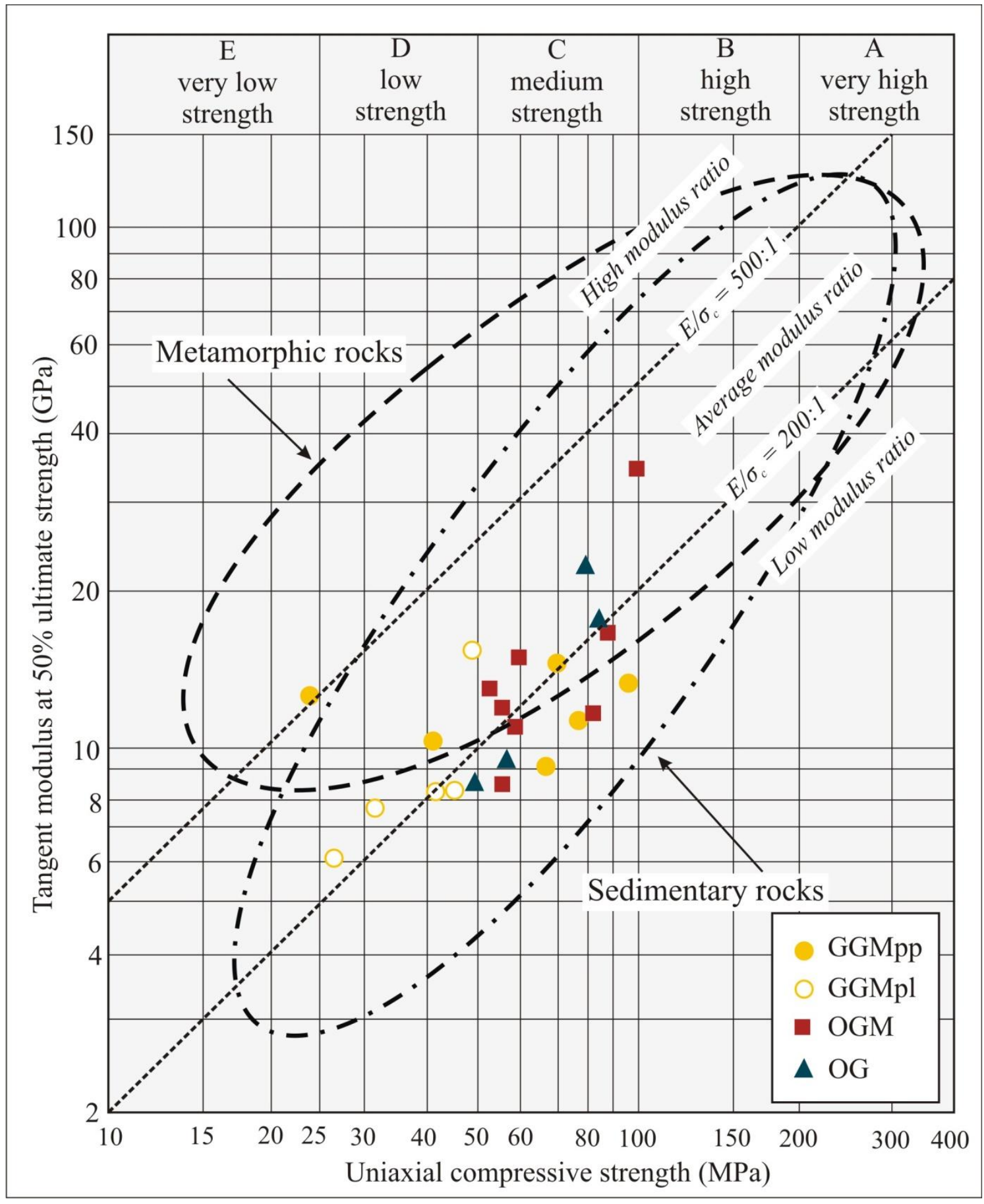

Fig. III.7. The concept of the Modulus Ratio (MR): a strength-deformation representation for rock materials and rock masses (Deere and Miller 1966) with the characteristic intervals of the metamorphic and sedimentary rocks.

The KIHA-NE data were plotted $(n=22)$ 
There are several rock mechanical classification schemes and interpretations used by rock engineers to describe the behaviour of rock masses (e.g., Q-system by Barton et al. 1974; NAMT by Rabcewicz 1964a, 1964b; Rock Mass Rating (RMR) system by Bieniawski 1989). These methods are mostly based on empirical observations and are developed for special rock mechanical problems. Although they define relative rather than absolute metrics, these schemes may be suitable for comparing the mechanical behaviour of diverse rock types within a given field. According to Deer and Miller's (1966) diagram $\left(\sigma_{c}-E\right)$, most studied samples plot into the sedimentary rather than the expected metamorphic rocks field, even if they are close to the boundary of the two fields (Fig. III.7). This suggests that the samples behave as sedimentary rocks in a mechanical sense; they do not show the features of classical metamorphic rocks. Although, their strength does not change significantly, the investigated samples have lower elasticity modulus than expected in the case of normal metamorphic rocks.

The different mechanical and fracture network parameters show characteristic relationships and co-variation trends (Fig. III.8). The CFL correlates with the D values; they increase together suggesting a more complicated fracture network consists of longer fractures. Fractal dimension is also in tight relationship with destruction work, such that the fracture system is more prone to better communicate when it was evolved by lower destruction work. It also suggests that the rock material with high $\mathrm{D}$ values is more brittle and easier to crush. According to the plots on Fig. $8 / b-c$, CFL could be useful in differentiating the samples by orientation, whilst the $\mathrm{D}$ value could be used for lithology differentiation. The plot of $\mathrm{W}_{\mathrm{d}}-\sigma_{\mathrm{c}}$ (Fig. III.8/a) may discriminate both concerning orientation and lithology. On each plot the OGM samples usually plot with intermediate values close to the few data points of OG. In the case of GGM lithology however, the data points of the parallel samples usually separate from the others; in addition, in several cases they separate from the perpendicular GGM data too. The remarkable influence of sample orientation on fracturing tendency suggests the highly anisotropic behaviour of the GGM lithology. In general, on the basis of all these plots, the parallel GGM samples need the lowest destruction work to create high CFL and D data that is a complex system. Consequently, this rock type has the best chance to form a communicating fracture network. Furthermore, orientation of the recent stress field may have an important role on the closing or opening tendency of the natural fractures of the GGM block inside the reservoir, because of the highly anisotropic behaviour of this lithology. 

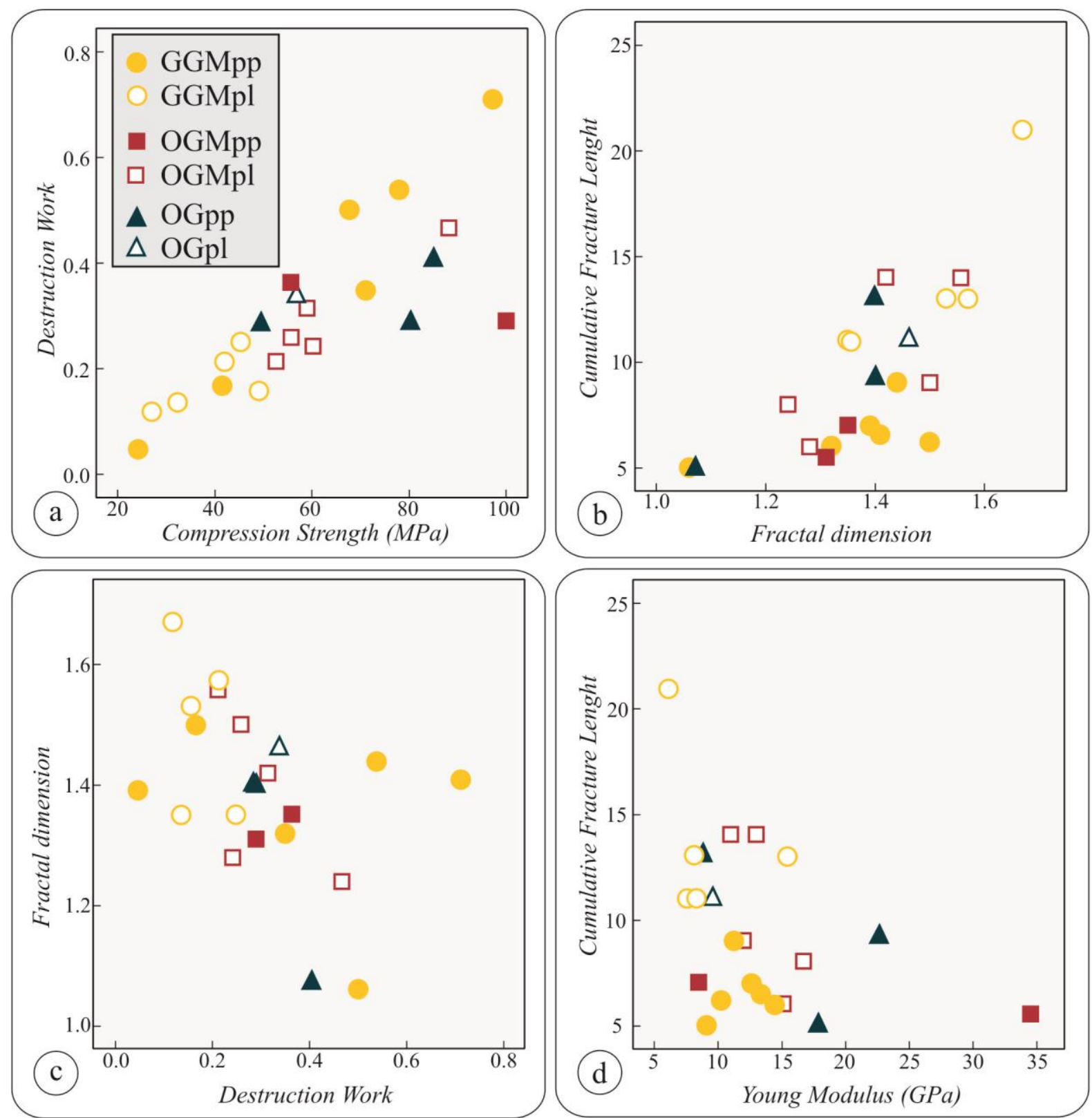

Fig. III.8. Cross plots of KIHA-NE data $(n=22)$ : (a) $W d-\sigma c$, (b) CFL-D, (c) $D-W d$, (d) $C F L-E$

Analysis of the CT images also makes the study of changes in the uncrushed rock matrix possible. This kind of evaluation can be carried out by omitting the fractures of the analysis. The results of intact and crushed samples were compared (Fig. III.5) in the case of the mylonitised rock units (OGM, GGM). Data obtained for the crushed OGM samples vary in a rather wide range, nearly overlapping with the original interval measured for the intact samples (Fig. III.5/b). As the HU values correlate with the rock density, the results suggest that in the case of the OGM, there was a slight density increase during the compressive test inside the rock matrix. Both the macroscopic and microscopic description, as well as the CT interpretation of this rock type, implies that the original OGM samples do not include a visible amount of microcracks or microcavities, which could become closed during the 
compressive test. Although, microcracks usually nucleate in mica neighbouring mineral phases, causing a density decrease and the OGM samples contain abundant amounts of phylosillicates (biotite, chlorite and sericite), the effect of this behaviour is not detectable on the CT scans. Even if this phenomenon may be important, the size and the amount of these microcracks in the samples are probably too low to appear in the HU values.

During deformation, as a result of the migrating fluids, fine grained muscovite + quartz assemblages form replacing relatively strong feldspars. Due to this process, the reaction softening (also called secondary) (e.g., White and Knipe 1978; Williams and Dixon 1982; Wibberley 1999) generates a softer, looser zone in the rock body. The muscovitisation reactions can facilitate the deformation (Wibberley 1999) and these reactions indicate fluid mobility in the shear zones during the deformation process (Williams and Dixon 1982). These softer zones afterwards undergo further loosening in the course of the uplift of the rock unit. Rock mechanical compression tests could generate compaction in these looser zones that may cause a density increase in the HU values of the specimens.

On the other hand, in the case of GGM, the HU parameters of the intact and crushed samples exhibit a characteristic difference. The difference between the HU modi (Fig. III.5/b) as well as the histograms of the crushed and intact GGM samples (Fig. III.5/a) clearly indicate a density increase during the mechanical treatment. This behaviour implies some essential rock characteristics may have an influence on the rock fracturing process. The GGM samples in their natural appearance contain abundant cracks, cavities and dissolved carbonate nests, which are probably accompanied by smaller microcracks and microcavities invisible to the naked eye. This microscopic and/or submicroscopic pore space could behave as significant matrix porosity that assigns a sedimentary feature for the rock, in accordance with the suggestion of the Deere and Miller (1966) plot (Fig. III.7).

Although, prior to sample preparation, naturally unfractured intact specimens were selected, the presence of a few microcracks, microcavies and dissolved nests cannot be discounted. During the compressive test these tiny unconformities may have closed and caused the density increase. As this phenomenon takes place on the microscopic scale and the $\mathrm{CT}$ scan has a $1 \mathrm{~mm}$ resolution, only the HU value distribution could serve information about the density change. Moreover, compaction of the loosened mica rich zones also plays a notable part in the density increase during the compression test.

In summary, we can state that the petrologically different rock types have remarkably different brittle behaviours. The low fracture network parameters (CFL, D) and the few provoked fractures detected on the CT images, confirm the former suggestion that the OG 
block does not behave as a good fractured reservoir. The OGM lithology is characterised by moderate anisotropy and fracture tendency; the fractal dimension and CFL values do not suggest formation of a complicated and connected fracture system. High anisotropy and the large, possibly communicating fracture system that characterises the GGM, is achieved by much lower work investment than for any other rock type. In fact, this mylonite variety behaves as a sedimentary rock based on its rock mechanical parameters. On the other hand, although this lithology is the best candidate to contain large fractured zones in the whole reservoir, at reservoir pressure conditions microcracks and microcavities may become closed, significantly decreasing the original matrix porosity. Otherwise, overpressure in the reservoir may keep the cracks open as well resulting just in the opposite effect.

\subsection{Discrimination of the lithology groups}

Detailed data evaluation clearly infers that the four rock types are different not only concerning their petrological characteristics, but also in their rock mechanical behaviour, especially in the ability to form mutual fracture systems. To quantify how well the lithology groups can be distinguished based on the measured numerical parameters, discriminant function analysis was applied. Furthermore, this approach also can identify those rock mechanical parameters that are responsible for characterising each group. In the first step, one can see that the OG and the OGM samples can be separated from the GGM specimens (Fig. III.9/a) using the discriminant function DA (Eq. 3) that is based mainly on destruction work and elasticity/compressive strength. The plots of the rock mechanical parameters also showed that the lithotypes can be separated using the $\mathrm{W}_{\mathrm{d}}-\sigma_{\mathrm{c}}$ (Fig. III.8/a) and the $\mathrm{E}-\sigma_{\mathrm{c}}$ (Fig. III.7) pairs of variables. Observing these plots, the OG with OGM group with higher strength and a slightly higher elasticity modulus, clearly needs more invested work to crush compared to the GGM samples. Furthermore, CFL, the third most important parameter of the DA discriminant function $(E q .3)$, is in a reverse relationship with the destruction work, suggesting that samples crushed using less work tend to generate more a complex fracture network. As the GGM needs less destruction work to be broken, coinciding with higher CFL values, the GGM lithology exhibits the better reservoir features.

Using discriminant analysis, no straightforward separation between the OG and OGM samples is possible (Fig. III.9/b). It is caused by gradual transition between the two rock types in all rock mechanical features (Fig. III.7), suggesting a continuous increase in the measure of shearing towards the highly deformed samples (mylonites). 
Thirdly, inside the GGM unit a remarkable difference can be computed between the parallel and the perpendicular samples. The bimodal feature of this lithology is slightly observable on Fig. III.9/a, whilst in Fig. III.9/c the separation of the differently orientated samples becomes obvious. In the DC discriminant function $(E q .5)$ that is responsible for separating samples of different orientations, the main factors are CFL and D that are the main geometric parameters of the fracture network. Absence of the rock mechanical variables indicates that there is no difference in the material itself, rather the behaviour of the GGM lithology is characterised by high anisotropy due to mylonitic foliation.

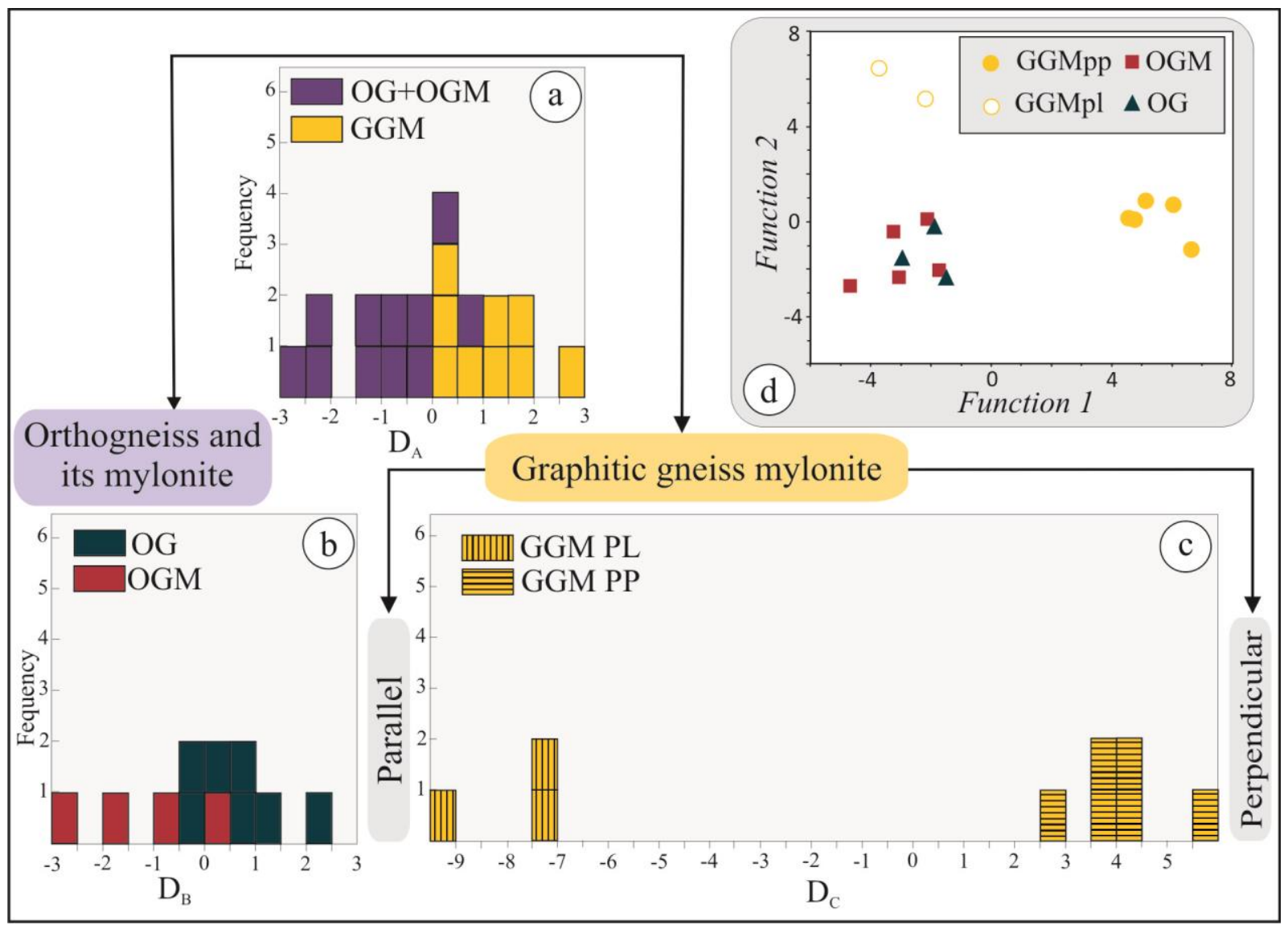

Fig. III.9. Histograms of the discriminant scores for the lithology groups.

a) orthogneiss $(O G)$ with its mylonite (OGM) and graphitic gneiss mylonite (GGM),

b) orthogneiss $(O G)$ and orthogneiss mylonite (OGM),

c) the parallel (PL) and the perpendicular (PP) graphitic gneiss mylonite (GGM)

Discriminant function analysis of all three petrologically different groups of rocks shows coincident results. In Fig. III 9/d three sample groups are separated; the OG and OGM form one cluster, while the parallel and perpendicular GGM samples create two additional groups. In the discriminant functions $\mathrm{F} 1$ and $\mathrm{F} 2($ Eqs. 6, 7) the primary differentiating factors are destruction work and compressive strength, while the secondly factors are cumulative fracture length and the fractal dimension value. The other rock mechanical and petrophysical 
parameters, like HU values, or the ultrasonic wave velocity have subordinate roles in the group formation.

\section{Conclusions}

The Kiskunhalas-NE fractured metamorphic reservoir is characterised by the presence of rock types with different metamorphic and structural evolutions. On the basis of complex investigation we can state that the petrologically different rock types have remarkably different rock mechanical behaviours. We suggest that graphitic gneiss mylonite zone may offer the best reservoir characteristics. The results also show that all mechanical parameters are highly anisotropic and are determined by previous structures of the rock types. Therefore, beyond the lithology, the relationships between the recent stress field and the orientation of the preserved foliation of the metamorphic rocks have an important role in the reservoir features. 


\title{
ChAPTER IV.
}

\section{LITHOLOGY IDENTIFICATION WITH WELL-LOG INTERPRETATION IN THE METAMORPHIC KISKUNHALAS-NE HYDROCARBON RESERVOIR, SOUTH Hungary}

\author{
Ágnes Fiser-Nagy \\ Department of Mineralogy Geochemistry and Petrology, \\ University of Szeged, Szeged, Hungary \\ agnes.nagy@geo.u-szeged.hu \\ Tivadar M. Tóth \\ Department of Mineralogy Geochemistry and Petrology, \\ University of Szeged, Szeged, Hungary \\ mtoth@geo.u-szeged.hu \\ Ilona Vargáné Tóth \\ MOL Hungarian Oil and Gas Company; \\ Budapest, Hungary \\ tvargane@mol.hu
}

submitted to

Acta Geodaetica et Geophysica Hungarica

on 9. July 2013 


\title{
Lithology identification with well-log interpretation \\ in the metamorphic Kiskunhalas-NE hydrocarbon reservoir, South Hungary \\ by: Ágnes Fiser-Nagy, Tivadar M. Tóth, Ilona Vargáné Tóth
}

\begin{abstract}
There are four main rock types along the ideal rock column of the Kiskunhalas-NE field; in order from the bottom upwards, orthogneiss, orthogneiss mylonite, graphitic gneiss mylonite and graphitic carbonate phyllite. These main rock types are characterized by significantly different reservoir features, as was proved by previous rock mechanical investigation. The geophysical information of well-logs (gamma, resistivity, neutron, density and acoustic logs) allow an understanding of the spatial extension of the good reservoir blocks. In the course of the examination of conventionally used plots, MN plots and discriminant function analysis were used. Three rock types were successfully identified along the wells, the graphitic carbonate phyllite, the mylonite and the orthogneiss. On the basis of the results, lithology boundaries could be estimated in numerous wells. These boundaries were presented along geological sections. Taking also the independent hydraulic regimes of the reservoir into account, a series of south-dipping normal fault-bounded blocks are assumed. Inside each block shallow-dipping mylonite/gneiss boundaries with a north-northeast dip direction are typical. The existence of this low-angled (less than $5^{\circ}$ ) mylonitized zone refers to a presence of a one-time detachment fault linked to the formation of a metamorphic core complex.
\end{abstract}

\section{Introduction}

Fluid production from a fractured hard rock reservoir with heterogeneous petrological build-up is a real challenge. Hydrodynamic features of the reservoir may differ significantly for diverse rock types, because of their various rheological behaviours. In certain cases, not only lithology, but also spatial position of rock bodies with considerable internal structures (bedding, foliation, etc.), may play a role in the resulting brittle deformation. In fact, the spatial relationship between the directions of the rock structures and the brittle stress field is crucial. All lithological and structural features may finally define the hydrodynamic characteristics of the reservoir, which commonly exhibits a highly compartmentalized nature.

The study area of this research is the Kiskunhalas-NE (KIHA-NE) fractured metamorphic basement reservoir from the southern part of the Pannonian Basin. Previous studies (Nagy et al. 2013) showed that the four basic rock types of this basement high behave in a remarkably different way in the brittle field, causing diverse fracture geometries. While various mylonitic rock types tend to produce a dense fracture network, orthogneiss is free from communicating fracture systems. Keeping also in mind that, in the KIHA-NE field at present, not less than ten independent domains are defined hydrodynamically, a complicated 
mosaic of differently fractured rock bodies must be supposed. In order to better understand the spatial position of blocks of rock types that tend to provide good reservoir qualities, a lithological framework should be put together. While the role of borecores is essential in petrological and petrophysical characterization, due to their very limited number well-logs must also be involved to spatially extend the information.

The aim of the present study is to maximize petrological and well-log information so as to construct a reliable framework of all rock types that play a remarkable role in the behaviour of the KIHA-NE reservoir.

\section{Geological settings}

The highly fragmented Pannonian Basin is built-up from microplates enclosed by the Carpathians, Alps and Dinarides. The rather complex structural evolution of the region started with the less known Variscan orogeny (Szederkényi 1984, Lelkes-Felvári et al. 2003, LelkesFelvári \& Frank 2006), followed by an extensive extension, known as the Jurassic (Csontos et al. 1992, Haas \& Péró 2004) and then the nappe formation in the Cretaceous (Rozlozsnik 1936, Ianovici et al. 1976, Bleahu et al. 1994, Német-Varga 1983, Tari et al. 1999). As a result of the complicated subsidence history of the Neogene (eg. Tari et al. 1992, Horváth 1995, Csontos \& Nagymarosi 1998, Horváth et al. 2006), even more kilometre-deep subbasins (Békés Basin, Makó Trench) and metamorphic highs, covered with just a few-hundredmetre-thick sediment (eg. Jánoshalma Dome, Szeghalom Dome), were formed (Fig. IV.1a). The so formed varied topography and structural setup of the basement significantly affect the fluid flow system of the basin (eg. Vass et al. 2009); therefore, knowledge of them is essential, especially with respect to the production of the industrially important fluids, like thermal water and hydrocarbons.

The KIHA-NE fractured metamorphic hydrocarbon-reservoir is situated inside the Tisza Unit, NE from the Jánoshalma Dome and southwest from the Tázlár field (Fig. IV.1/a). The 69 wells of the field reach the metamorphic basement at 1800-2000 m deep and generally extend for tens or even hundreds of metres. The previous papers (T. Kovács 1973, Árkai 1978, Cserepes 1980, T. Kovács \& Kurucz 1984, Cserepes-Meszéna 1986, Árkai 1993) dealing with the field outline a diverse petrological build-up and various developments. 


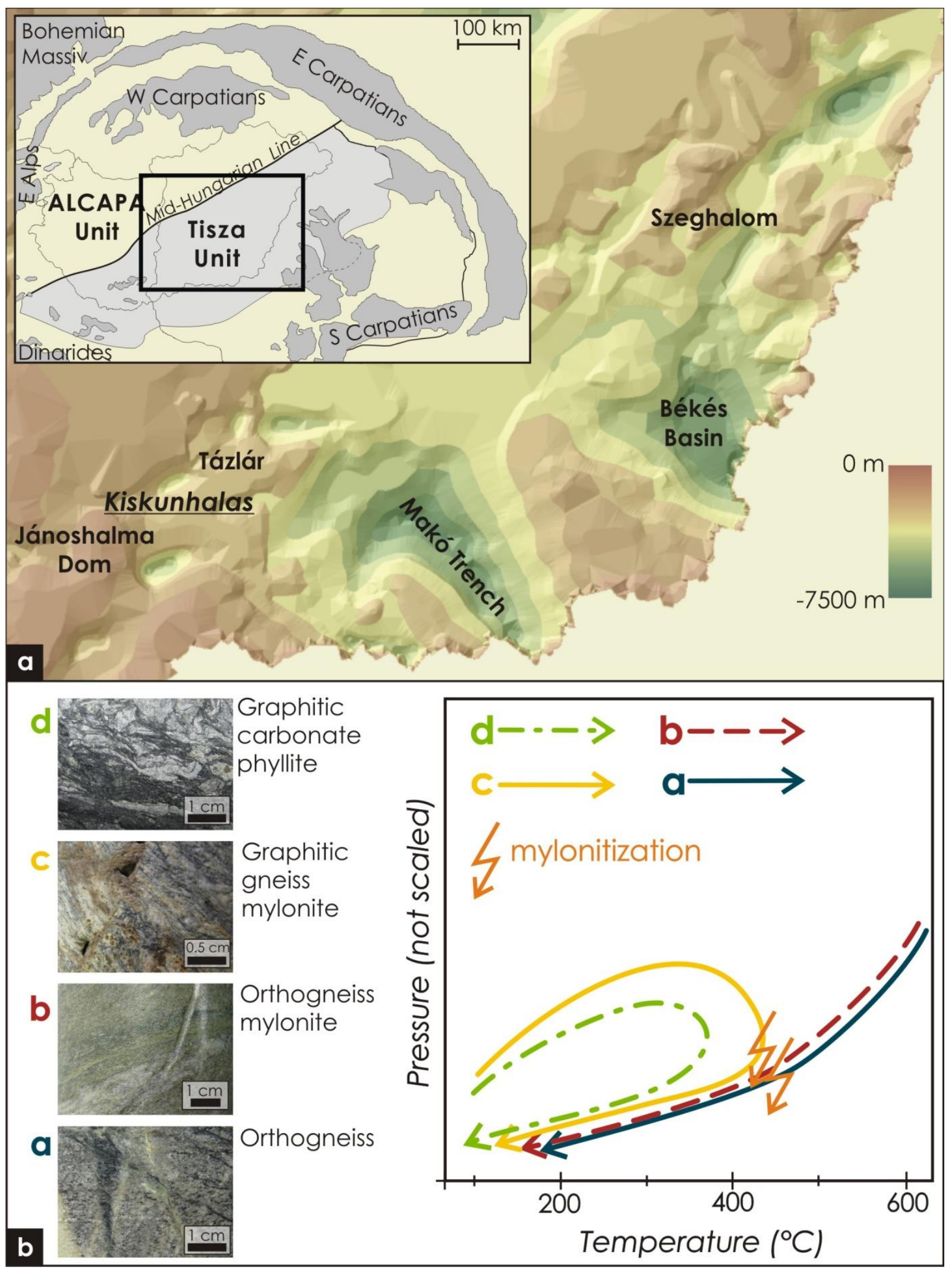

Figure IV.1. a) Location of the Kiskunhalas-NE field in the Pannonian Basin (After Haas et al. 2010). b) Representative macroscopic picture of the litotypes in the order of the ideal rock column and metamorphic evolution of them (after Nagy \& M. Tóth, 2012).

According to Nagy and M. Tóth (2012) there are four main rock types in the metamorphic basement of KIHA-NE in the ideal rock column (Fig. IV.1/b), as follows. In the 
lowermost structural position, an orthogneiss with amphibolite xenoliths is common. On the basis of the petrological characteristics it is similar to the orthogneiss body of the neighbouring Jánoshalma Dome $\left(T_{1} \sim 700-850{ }^{\circ} \mathrm{C}, P_{1}<0.65 \mathrm{GPa}\right.$ and $T_{2}<580{ }^{\circ} \mathrm{C}$, Zachar and M. Tóth 2004). The next lithology unit upwards is the mylonitized orthogneiss that, in the mineral assemblage sense, clearly deviates from the next graphitic gneiss mylonite type. The extensional fabric elements (C/S fabric, apatite bookshelf, boudinaged clasts and deformed quartz grains) are common in both mylonite types. In accordance with the quartz suture thermometer (Kruhl and Nega 1996), the temperature of the deformation event of these two mylonite types is estimated as $T_{d e f} \sim 455^{\circ} \mathrm{C}$ and the metamorphic temperature of the graphitic gneiss mylonite is $T \sim 410 \pm 45^{\circ} \mathrm{C}$ using a carbonaceous material thermometer by Raman microspectroscopy (Beyssac et al. 2002, Rahl et al. 2005, Ayoa et al. 2010). The uppermost member of the ideal rock column, a graphitic carbonate phyllite, occurs only in a limited area of the site. Its carbonaceous material thermometer results suggest a $T \sim 370 \pm 15{ }^{\circ} \mathrm{C}$. In accordance with the previous and more recent outcomes between the bottom (orthogneiss) and the top (graphitic carbonate phyllite) of the rock column, there is approximately $200{ }^{\circ} \mathrm{C}$ difference in the characteristic metamorphic temperatures. The evolution of the two extreme rock bodies is significantly different and they were probably juxtaposed along an extensional shear zone (Nagy and M. Tóth 2012).

\section{Methods}

There is no outcrop in the basement; we only have information from several wells, penetrating the metamorphic mass around $100 \mathrm{~m}$ deep. Because of the limited sources of information, we have to involve all data from the wells; the drilling documentation, the borecore samples and cuttings, as well as the well-logs; as follows (Fig. IV.2).

\subsection{Drilling documentation}

Drilling documentation is the primary information about a well; it follows the "life" of the well from planning to closure. The daily report provides essential information about the presence and the extension of the lithotypes in the intervals without borecores. The lithotypes and the depths of the lithotype changes were determined primarily on the basis of the cuttings. Nevertheless, detailed petrographic examination could not be carried out based on on-the-spot cuttings because of their small size and the short time available for description. Therefore, the 
lithology classification on the well site is restricted to the macroscopically obvious differences.

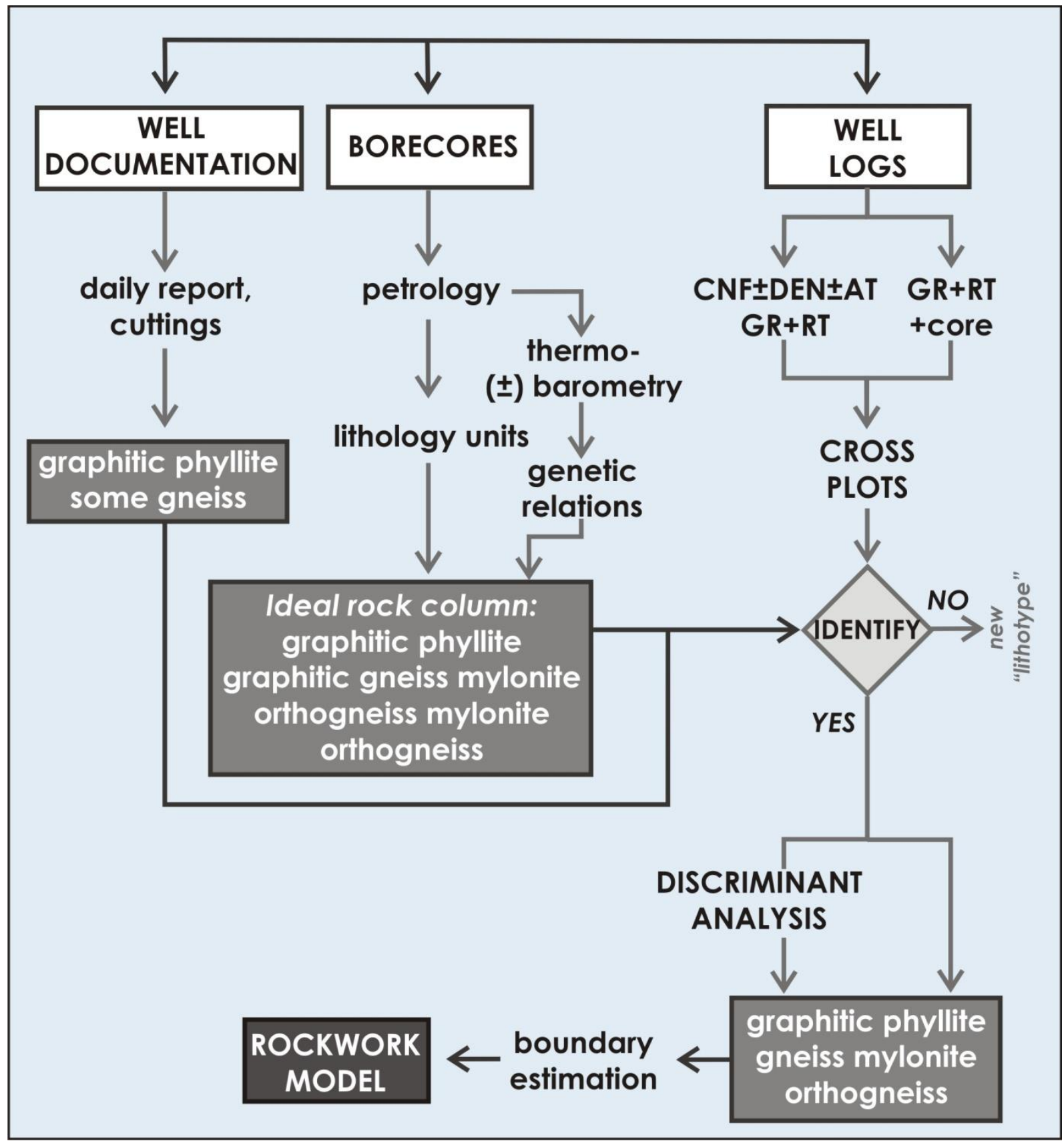

Figure IV.2. Flow chart of the methods (see further in the text).

\subsection{Lithological classification}

Accurate petrological information can be achieved only at the points of the borecores. In the borecores with conventional petrographic investigation (macro- and microscopic examination) the mineralogical composition, textural characteristics, and the extent of deformation could be established. On the basis of these characteristics, we can classify the 
rock types of the field. Estimation of the metamorphic pathway (thermo- and barometric) helps in understanding the genetic relationship between the separated lithotypes that allow the definition of the (approximate) order in the ideal rock column. Even so, our lithological knowledge is limited to the sporadic borecores.

\subsection{Well-log data evaluation}

The several-decades-old well-logs were digitalized and only the good quality borehole logs were selected. If necessary, correction was applied to the logs. As only the metamorphic basement was the object of the present study, only these intervals were examined, the other sections were cut off. Most of the wells' own good quality logs do not contain a borecore, thus we could not apply a direct borecore-log dataset. Instead, only the results of the petrological descriptions of the identified lithotypes and their ideal sequence along the rock column were considered.

On the digital data of the geophysical measurement, two-log (cross plots) and multi-log (MN plot) quantifications were computed, in order to group the log values and identify the known lithotypes. Further statistical investigations (discriminant function analysis) were fulfilled to find the best separation algorithm between the lithology units. Furthermore, to estimate the rock type boundaries, the "predicted group" option of discriminant function analysis was used.

Cross plot is a simple graphical method to solve fairly complex relationships using two (or three) geophysical measurements; it can help to estimate the formation lithology. It has a general format; one measurement is displayed along the $\mathrm{x}$-axis and another is displayed along the y-axis (Asyuith and Krygowsky 2004). The third measurement can be plotted with a colour scale. We can group the well-log values to define fields, also taking into account the depth of the data points, and relations between the two variables (Riden 1996, Steckham and Sauer 2010).

$M N$ plot is a multi-log quantification; it combines the data of all three porosity logs to provide the lithology-dependent quantities $M$ and $N . M$ and $N$ are simply the slopes of the individual lithology lines on the sonic-density and density-neutron cross plot charts, respectively. Thus, $M$ and $N$ are essentially independent of porosity and a cross plot provides lithological identification (Schlumberger 1989). $\mathrm{M}$ and $\mathrm{N}$ are defined as:

$$
\begin{aligned}
& \mathrm{M}=\left(\Delta \mathrm{t}_{\mathrm{fl}}-\Delta \mathrm{t}\right) /\left(\rho_{\mathrm{b}}-\rho_{\mathrm{fl}}\right) \times 0.01(\text { × } 0.03 \text { metric }) \\
& \mathrm{N}=\left(\varphi_{\mathrm{Nfl}}-\varphi_{\mathrm{N}}\right) /\left(\rho_{\mathrm{b}}-\rho_{\mathrm{fl}}\right)
\end{aligned}
$$


where $\Delta \mathrm{t}$ is the interval transit time in the formation (from the $\log$ ), $\Delta \mathrm{t}_{\mathrm{fl}}$ the interval transit time in the fluid in the formation, $\rho_{b}$ the formation bulk density (from the log), $\rho_{\mathrm{fl}}$ fluid density in the formation, $\varphi_{\mathrm{N}}$ neutron porosity (from the $\log$ ), $\varphi_{\mathrm{Nfl}}$ neutron porosity of the fluid of the formation (usually =1.0). A number of common mineral points are plotted on the MN plot; conventionally this defines the limestone-sandstone-anhydrite-dolomite quadrangle (Asyuith and Krygowsky 2004), which are the common (sedimentary) reservoir lithologies. Although, in this case, the KIHA-NE reservoir is a hard rock reservoir, this conventional quadrangle was used to facilitate the simple orientation inside the $M N$ plots.

Discriminant function analysis is a suitable statistical method of assigning lithotypes to the log values; its task is to find the class, among those currently available, and that which most closely matches each unclassified sample. Therefore, this calculation requires a priori knowledge of classes (Benaouda et al. 1999). We aim to find the best separations in the datasets and estimate or evaluate the boundaries among the lithotypes along the wells.

\subsection{The available open-hole well-logs}

The gamma $(G R) \log$, a measurement of the natural radioactivity of the formations, derives from ${ }^{40} \mathrm{~K},{ }^{238} \mathrm{U},{ }^{232} \mathrm{Th}$ and their daughter elements. In a non-radioactive formation, the potassium content is the dominant accompanied by clay minerals and potassium feldspar (Schlumberger 1989).

Because dry rocks are good electrical insulators, the resistivity $\log (R T)$ shows the fluid in the pores of the formations or that absorbed in their interstitial clay. The resistance of a formation depends on the amount and the resistivity of formation water and the pore structure geometry (Schlumberger 1989). Each formation without fluids could have a different resistivity because of the different amount of included conductive minerals. The resistivity log is on the logarithmic scale, unlike the others; therefore, the following transformation commonly used in the case of metamorphic rocks, was applied to them.

GYRT $=1 / \sqrt{ }$ RT

The sonic log measures interval transit time ( $\Delta t$ or DT) of a compressional sound wave travelling through the formation along the axis of the borehole (Asyuith \& Krygowsky 2004). In the simplest form, a sonic tool consist of a transmitter that emits a sound pulse and a receiver that picks up and records the pulse as it passes the receiver. Porosity decreases the velocity of the sound through the rock material and, correspondingly, increases the interval 
transit time. The interval transit time for a given formation depends on its lithology and porosity (Schlumberger 1989).

The density $\log$ measures the matrix density and the density of the fluid in the pores (Asyuith \& Krygowsky 2004). A radioactive source applied to the borehole wall emits gamma rays into the formation (Schlumberger 1989). When the emitted gamma rays collide with electrons in the formation, the collisions result in a loss of energy from the gamma ray particle. The scattered gamma rays returned to the detectors in the tool measured on high energy range, are proportional to the electron density of the formation. In most earth materials of interest in hydrocarbon exploration, the electron density is related to the formation true bulk density $\left(\rho_{b}\right)$ through a constant (Tittman \& Wahl 1965). The formation bulk density is a function of matrix density, porosity and density of the fluid filling the pores (Asyuith \& Krygowsky 2004).

Neutron $\log s\left(\varphi_{N}\right)$ respond primarily to the hydrogen concentration in a formation. In a shale-free porous formation, where pores are filled with water or oil, the neutron log reflects the liquid filled porosity. Neutrons are created from a chemical source in the neutron logging tool. These neutrons collide with nuclei of the formations and with each collision the neutron loses some of its energy. With enough collision, the neutron is absorbed by a nuclei and a gamma ray is emitted. Because the hydrogen atom is almost equal in mass to the neutron, maximum energy loss is dominated by a hydrogen atom. Therefore, the energy loss is dominated by the hydrogen concentration of the formation. The neutron log responses depend on the detector type and the lithology (Asyuith \& Krygowsky 2004, Schlumberger 1989).

As, in this case, the porosity of the known basement lithologies of the investigated area is rather low, the porosity logs practically respond to the lithology features.

\section{Data}

\subsection{Drilling documentation}

In the basement of the KIHA-NE field, the daily reports separate two different rock types on the basis of cuttings; the graphitic carbonate phyllite and some kind of gneiss (Fig. $I V .2)$. Due to the rather characteristic appearance of the graphitic carbonate phyllite (black colour), its location and the exact extension are well documented in the whole area. 


\subsection{Petrological information}

The lithological classification and detailed petrographical description of the lithological units of Nagy and M. Tóth (2012) were used in the course of the present examination.

The orthogneiss of the KIHA-NE area consists of unweathered feldspar and quartz, and various amounts of biotite and muscovite flakes determine the slight foliation. Moderate weathering presents in just some places in the samples, while along the small number of narrow cracks small-scale alteration zones are common. There are a few amphibolite xenoliths and mica-poor granite dykes intercalated in the orthogneiss body (Fig. IV.1/b).

The mineral assemblage and fabric elements (myrmekitic feldspar grains) of the orthogneiss mylonites suggest the relation to the orthogneiss underneath. The protolith orthogneiss underwent a strong shearing effect. As a consequence, the feldspars were sericitized, the biotite altered to chlorite, while mylonitic $(\mathrm{C} / \mathrm{S})$ foliation developed. A moderate amount of fractures and cracks is characteristic without any alteration zone and considerable open pore space in the orthogneiss mylonite rock body does not exist (Fig. $I V .1 / b)$.

In the case of the graphitic gneiss mylonite, the intensive sericitization, the $\mathrm{C} / \mathrm{S}$ foliation and mylonitic fabric elements are the same as in the orthogneiss mylonite samples. However, the absence of biotite and/or chlorite, and the presence of graphite and sulphide minerals as index phases, clearly separate this block from the underlying orthogneiss mylonite. The samples are commonly fractured and oil spotted, containing significant open pore spaces (Fig. $I V .1 / b)$.

On the top of the basement, the mostly chaotically folded graphitic carbonate phyllite appears. In this low grade metamorphic rock, black bands alternate with white bands (Fig. $I V .1 / b)$. The major rock forming minerals are graphite (black bands), carbonate and white mica (white bands), with subordinates containing sulphide minerals and some quartz too. The mylonitic features are absent; nevertheless, extensional fabric elements (pressure fringes around pyrite cubes) are characteristic of its texture.

\subsection{Well-logs}

As mentioned above, the only geophysical data available in the KIHA-NE field are the several-decade-old digitalized well-logs; a seismic section does not pass through the investigated area. Fifteen out of the total of 69 wells have invaluable well-logs with porosity 
logs. Altogether, nine wells have all three porosity logs, two have five wells without any borecores, and one has only the neutron log, but it also has borecores. Further four wells, with only the gamma and resistivity logs, were used in the course of the evaluation because of their lithologically various borecores (Table IV.1).

\begin{tabular}{|c|c|c|c|c|c|c|c|c|c|c|c|}
\hline \multicolumn{7}{|c|}{ Avaiable porosity } & \multicolumn{3}{c|}{$\begin{array}{c}\text { Discriminant fuction } \\
\text { analysis }\end{array}$} & Plot & $\begin{array}{l}\text { Lithology } \\
\text { boundary }\end{array}$ \\
\hline Well & N & D & S & Core & N-D-S & N-D & N-S & N & N & GR-RT & lit \\
\hline A & $\#$ & $\#$ & $\#$ & & OK & & & & & & $\mathrm{G} / \mathrm{M}$ \\
\hline B & $\#$ & $\#$ & $\#$ & & OK & & & & & & $\mathrm{G} / \mathrm{M}$ \\
\hline C & $\#$ & $\#$ & $\#$ & & OK & & & & & & $\mathrm{G} / \mathrm{M}$ \\
\hline D & $\#$ & $\#$ & $\#$ & & OK & & & & & & $\mathrm{G} / \mathrm{M}$ \\
\hline E & $\#$ & $\#$ & $\#$ & & OK & & & & & & $\mathrm{G} / \mathrm{M}$ \\
\hline F & $\#$ & $\#$ & $\#$ & & D(1) & D(2) & D(3) & D(4) & OK & & $\mathrm{G} / \mathrm{M}$ \\
\hline G & $\#$ & $\#$ & $\#$ & & OK & & & & & & $\mathrm{G} / \mathrm{M}$ \\
\hline H & $\#$ & $\#$ & $\#$ & & OK & & & & & & $\mathrm{G} / \mathrm{M}$ \\
\hline I & & & & $\#$ & & & & & & $\mathrm{X}$ & $\mathrm{M} / \mathrm{M}$ \\
\hline J & & & & $\#$ & & & & & & $\mathrm{OK}-\mathrm{X}$ & $\mathrm{G} / \mathrm{M} / \mathrm{M}$ \\
\hline K & $\#$ & $\#$ & & & & OK & & & & & $\mathrm{G} / \mathrm{M}$ \\
\hline L & $\#$ & $\#$ & & & & OK & & & & & $\mathrm{G} / \mathrm{M}$ \\
\hline M & $\#$ & $\#$ & & & & OK & & & & & $\mathrm{G} / \mathrm{M}$ \\
\hline N & $\#$ & $\#$ & & & & OK & & & & & $\mathrm{G} / \mathrm{M}$ \\
\hline O & $\#$ & & $\#$ & & & & $\mathrm{X}$ & & & & $\mathrm{G} / \mathrm{M}$ \\
\hline P & $\#$ & & $\#$ & & & & $\mathrm{X}$ & & & & $\mathrm{G} / \mathrm{M}$ \\
\hline Q & $\#$ & & & $\#$ & & & & OK & D(5) & OK & $\mathrm{G} / \mathrm{M}$ \\
\hline R & $\#$ & $\#$ & $\#$ & & $D(6)$ & & & & & OK & $\mathrm{P} / \mathrm{M}$ \\
\hline S & & & & $\#$ & & & & & & OK & $\mathrm{P} / \mathrm{M}$ \\
\hline
\end{tabular}

Table IV.1. Summary of the used wells and results of them.

Legend: $N$ - neutron log, $D$ - density log, $S$ - sonic log, $D(1)$ - number of the discriminant function, OK - the discriminant analysis was worked, $X$ - the discriminant analysis was not worked, $G / M-$ gneiss/mylonite lithology boundary, M/M - mylonite/mylonite lithology boundary, P/M - graphitic carbonate phyllite/mylonite lithology boundary.

\section{Results and discussion}

\subsection{Separation and identification of the orthogneiss and the mylonitic lithologies}

First, let us look at those wells, which, according to the cuttings, did not contain graphitic carbonate phyllite. Consequently, the "gneissic" lithology of the field notes could be identified as one of the remaining three rock types (mylonites and orthogneiss). There are some wells with a limited porosity log range, but which have numerous borecores from the gneiss and some from the mylonitic rock types. In the case of Well-Q, there are several 
borecores belonging to the orthogneiss and its mylonitic variety. On the plot of gammaresistivity, the data points of its borecores (the coloured circles) appear separately (Fig. $I V .3 / a)$, and the further values are grouped around them. The points around the gneiss mylonite connect to the upper section of the well, while the other group, around the gneiss borecore data points, belongs to the lower section of the well. The mylonitic interval is characterized by higher gamma values and lower resistivity than those typical of the gneiss group.

In Well-J, according to the numerous borecores, three lithotypes are represented; graphitic gneiss mylonite, orthogneiss mylonite and orthogneiss. Even so, on its gammaresistivity cross plot, just two groups exist (Fig. IV.3/b); the datapoints of the orthogneiss samples are separated from the mylonitic samples. The graphitic gneiss mylonite and the orthogneiss mylonite borecore values appear as overlapping groups; thus, despite the clear petrological difference, the two mylonitic lithotypes do not deviate in a well-log sense. The result of Well-I corroborates that the mylonitic lithologies of KIHA-NE are not separable in a well-logging way, since its graphitic gneiss mylonite and orthogneiss mylonite borecores do not deviate on its cross plots. In Well-J, the log values of the short interval without borecores coincide with the orthogneiss group, confirming the suggested identification by their depth. The group of mylontic lithotypes presents with higher gamma values compared with the orthogneiss datapoints.

Eight wells have all porosity logs, but without any available borecores. In these cases, all the porosity logs were plotted with each other in every possible variation in all cases. The points of all the wells suggest the existence of diverse groups in these diagrams. The best separation is shown by Well-F, where the two groups clearly appear on each plot, being the most spectacular on the density-sonic plot (Fig. IV.3/c). Furthermore, samples of these groups cluster separately along the well; the upper section of the well is characterized by lower density and higher $\Delta t$ compared to the lower section. Nevertheless, the two separated intervals of the well do not show any noticeable deviation in gamma values.

The lithology sensitive MN plot needs all three porosity logs, so it was completed only for those wells with all of them. To assists the orientation on the MN plot, merely for the sake of simplicity, the conventionally used quadrangle of anhydrite (A) - sandstone (S) limestone (L) - dolomite (D) was used. The obtained MN plots generally show two groups with varied standard deviations, and, in some cases, only one of the groups is present. The best example to exhibit the strength of the MN plot is Well-F (Fig. IV.3/d), where both groups exist separately. The upper section of the well is represented by points along the lower side 
(A-S) of the quadrangle, while the lower section of the well exists along the upper side (DL). Two further separated groups appear on this plot; namely the data points of the potassium feldspar-rich intervals (Fig. IV.3/d) and the calcium and sodium feldspar-rich intervals (Fig. $I V .3 / d)$. These short intervals are dispersed along the well.

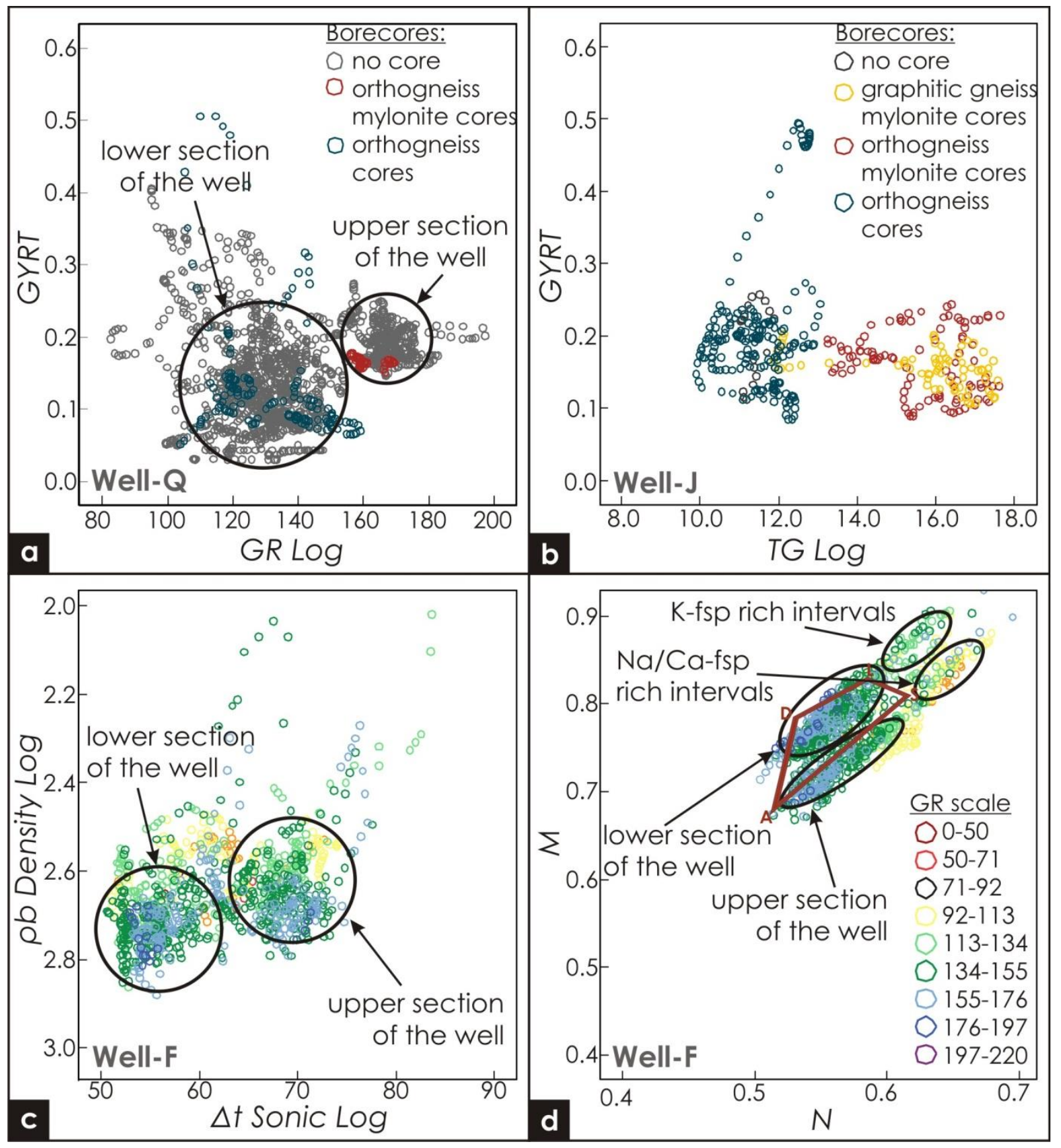

Figure IV.3. Plots of gneiss and mylonitic lithologies: a) Gamma-Resistivity plot of well-Q; b) Gamma-Resistivity log of well-J; c) Sonic - Density plot of well-F; d) MN plot of well-F. Legend: $A$ - anhydrite, $S$ - sandstone, $L$ - limestone, $D$-dolomite.

The two groups of the MN plot along the lower and the upper sides of the quadrangle coincide with the groups separated on the cross plots previously (Fig. IV.3/c). The upper 
interval of the well is characterized by lower density and higher sonic values compared to the underneath section. This could mean that the upper interval is looser and has higher mica content; the latter also is responsible for higher gamma values (Fig. IV.3/a, b). These features together with considering the ideal sequence along the rock column (Fig. IV.1/b), suggest that the group along the A-S side of the quadrangle belongs to the mylonitic rock types. Because of shearing and its attendant alteration process, the mylonitic zones are looser and are richer in micas than the non-deformed orthogneiss body. As a result, the other group along the D-L side of the quadrangle is identified as the orthogneiss lithology. In the cases where only one of these groups appears on the MN plot, there is just one lithology along the whole well: orthogneiss or mylonite.

\subsection{Estimation of the boundary between orthogneiss and mylonitic lithologies}

After the separation and identification of the gneiss and mylonite lithotypes, we would like to know which well-log measurements and the extent to which the separation between the two lithologies are defined. For this purpose, discriminant function analysis was carried out. In the first step, all porosity log data of Well-F were used with the aim of defining the function which best separates the two lithologies. In the second step, this function can be applied to all other wells. As a result, the boundary between the separated lithology units can be estimated using the predicted membership values computed by discriminant analysis.

Figure IV.4/a shows the histogram of the discriminant scores of Well-F with the two fairly well separated groups of mylonite and gneiss values. The higher discriminant score values concern the mylonite lithology, while the lower discriminant score values refer to orthogneiss. According to the discriminant function:

$\mathrm{D}(1)=(0.361 * \mathrm{~S}+2.146 * \mathrm{D}+5.393 * \mathrm{R})-(0.389 * \mathrm{~N}+26.297)$

the dominant parameters in the separation are density (D) and resistivity (R) besides the neutron $(\mathrm{N})$ and sonic $(\mathrm{S}) \operatorname{logs}$. In Figure $I V .4 / b$ discriminant scores along the depth are present; the boundary between the two lithologies can be estimated at $2094.7 \mathrm{~m}$ on the basis of the predicted group membership values calculated for the $\mathrm{D}(1)$ discriminant function.

Afterwards, the $\mathrm{D}(1)$ function was applied for the remaining seven wells with all porosity logs. One example is demonstrated, the case of Well-D, in Figure $I V .4 / c, d$. The resulting scores of $\mathrm{D}(1)$ are plotted with the depth (Fig. IV.4/d); the upper section of the well belongs to the mylonite lithology and has higher discriminant score values compared to the lower interval of the borehole, that is, the non-deformed gneiss. This identification is 
confirmed by the MN plot results also, shown on Figure IV.4/c. The boundary was estimated at $2100.8 \mathrm{~m}$ between the mylonite and the gneiss units. The extremely high values of the gneiss unit (Fig. IV.4/b, $d$ ) might belong to narrow sheared zones, while the much lower score values inside the mylonite unit could represent less mylonitized bands, as the log features of these intervals are closer to that common for the gneiss type.

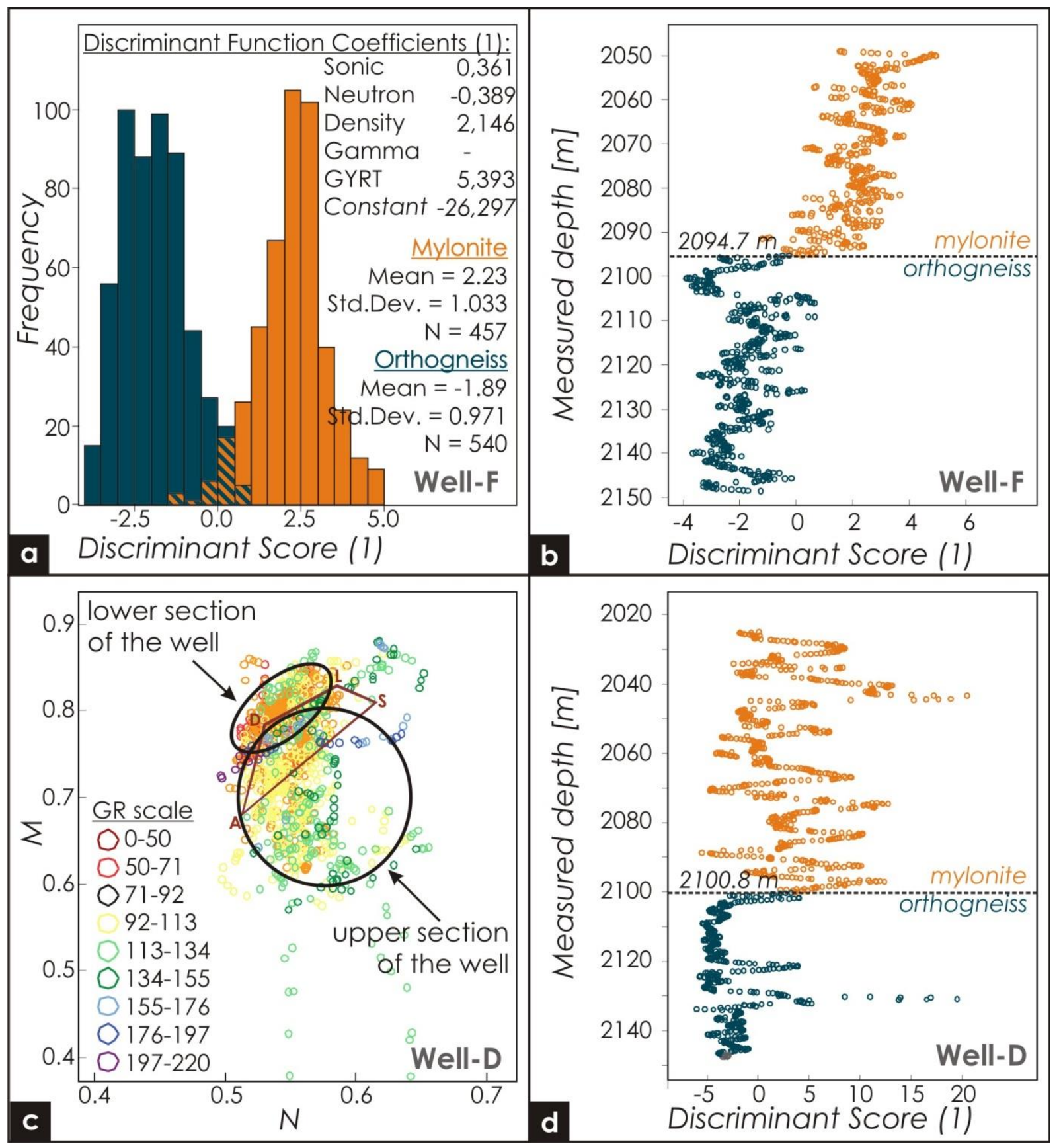

Figure IV.4. Discriminant function analysis (D1) of gneiss and mylonite with density, sonic, neutron logs: a) histogram of the discriminant scores $(D 1)$ of well-F; b) discriminant scores $(D 1)$ of well-F along the well; c) MN plot of well-119; d) discriminant scores (D1) of well-119 along the well.

Legend: $A$ - anhydrite, $S$ - sandstone, L-limestone, $D$ - dolomite 


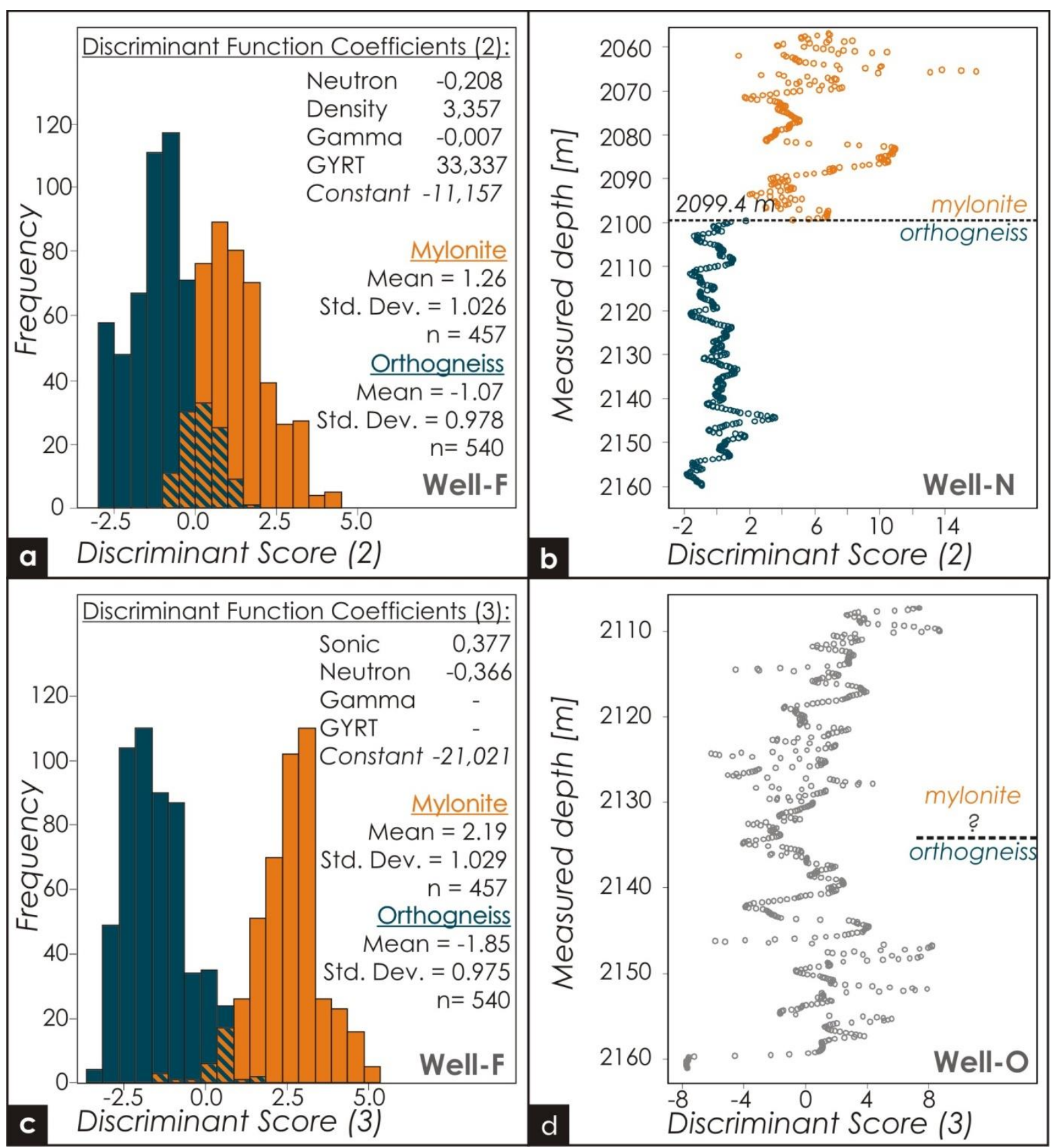

Figure IV.5. Discriminant function analysis (D2) of gneiss and mylonite with density and neutron logs: a) histogram of the discriminant scores (D2) of well- $F$; b) discriminant scores (D2) of well- $N$ along the well. Discriminant function analysis (D3) of gneiss and mylonite with sonic and neutron logs: c) histogram of the discriminant score (D3) of well-F; d) discriminant scores of well-O along the well.

There are some wells without the whole range of porosity logs; either the density or the sonic is absent. Although, in these cases, the MN plot is unusable, the discriminant function analysis might be successful. Identically to the previous seven cases, the discriminant scores of the $\mathrm{D}(1)$ function consistently show that the mylonites have higher values (ca. > 0) and the orthogneiss have lower values $(\mathrm{ca} . \leq 0)$. So, as the results of $\mathrm{MN}$ plots and discriminant 
analysis coincide, in all cases when the MN plot cannot be applied in the absence of any of the porosity logs, lithologies can be separated using the statistical approach alone. The previously efficiently used dataset of Well-F was used in the cases where one of the porosity $\log$ is absent. At first, calculation without sonic measurements was carried out. In this case, the gneiss and mylonite zones of Well-F could well be separated (Fig. IV.5/a) using the function of:

$\mathrm{D}(2)=(3.357 * \mathrm{D}+33.337 * \mathrm{R})-(0.208 * \mathrm{~N}+0.007 \mathrm{G}+11.157)$.

The resistivity (R) and the density (D) logs are the main parameters in the separation besides the neutron $(\mathrm{N})$, while the gamma $\log (\mathrm{G})$ has a very low effect on it. The $\mathrm{D}(2)$ function was applied successfully on all wells with only density and neutron porosity and without sonic logs; the lithology and the boundary of all these wells could be estimated convincingly. As in the case of Well-N (Fig. IV.5/b), the upper interval of the well is mylonite up to $2099.4 \mathrm{~m}$, while further down orthogneiss is common.

In the other case, where the density log is missing and sonic and neutron are involved from the porosity logs, the discriminant analysis of Well-F produces the histogram in Figure $5 c$, where the separation of the mylonite and gneiss lithology is quite good, using the function of:

$\mathrm{D}(3)=(0.377 * \mathrm{~S})-(0.366 * \mathrm{~N}+21.021)$.

But the application of the $\mathrm{D}(3)$ function for the wells does not work; in the example of Well-O the discriminant scores (Fig. IV.5/d) do not show any pattern similar to the previous ones, neither the identity of the lithologies nor the boundary between them could be established. Nonetheless, this experiment further confirms that, when separating gneiss and mylonite, the density measurement plays the major role (together with the resistivity), and the sonic log is not suitable.

Finally, Well-Q, with only the neutron measurements from the porosity logs, explores some borecore samples from both orthogneiss and its mylonite. According to the previous practice, the dataset of Well-F was the starting point of the discriminant function analysis. On the histogram of the discriminant scores (Fig. IV.6/a) separation of the two lithologies is satisfactory using only the neutron, gamma and resistivity measurements; the function is:

$\mathrm{D}(4)=30.834 * \mathrm{R}-(0.245 * \mathrm{G}+2.714)$

The main separating $\log$ is the resistivity $(\mathrm{R})$, the gamma $(\mathrm{G}) \log$ is subordinate, while the neutron $(\mathrm{N})$ has no role. The $\mathrm{D}(4)$ function was applied on the dataset of Well-Q and the resulting discriminant scores along the depth are shown in Figure IV.6/b with locations of the known borecores (coloured circles). The known intervals fit into the separated sections of 
mylonite and orthogneiss. The boundary between the two lithology units was estimated at a depth of $2081.7 \mathrm{~m}$. There is an interval (without sample) around the $2160 \mathrm{~m}$ depth in the orthogneiss unit, with consistently higher discriminant score values; this might be a sheared zone inside the otherwise non-deformed orthogneiss unit.

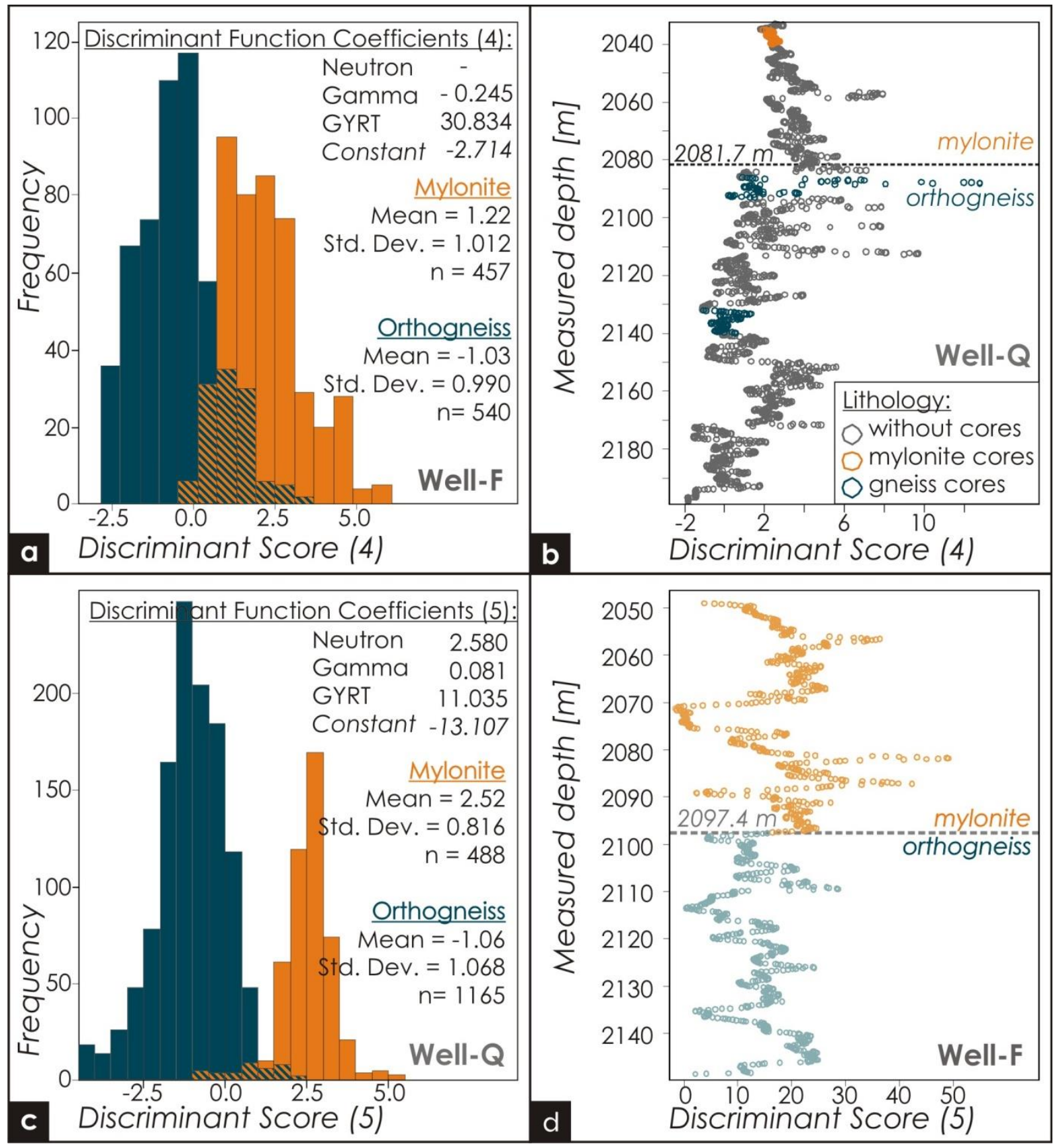

Figure IV.6. Discriminant function analysis (D4) of gneiss and mylonite with neutron: a) histogram of the discriminant scores of well-F; $b$ ) discriminant scores (D4) of well- $Q$ along the well; $c$ ) histogram of the discriminant score (D5) of well- $Q d$ ) discriminant scores (D5) of well-F along the well.

Finally, discriminant analysis was carried out on the dataset of Well-Q too in order to check whether the $\mathrm{D}(5)$ function works satisfactorily on the dataset of Well-F. The 
discriminant scores of Well-Q appear with quite good separation (Fig. IV.6/c), with the function of:

$\mathrm{D}(5)=(11.035 * \mathrm{R}+2.580 * \mathrm{~N}+0.081 * \mathrm{G})-13.107$

Similar to $\mathrm{D}(4)$, the most dominant measurement is the resistivity $(\mathrm{R})$; but the neutron $\log (\mathrm{N})$ has a greater role than the gamma $(\mathrm{G})$, contrary to Equation 7. The plot of the discriminant scores of Well-F by Equation 8 are presented in Figure IV.6/d. The previously identified lithologies (Fig. IV.3/a, b, Fig. IV.4/a, b) are indicated in it. Although the separation is not as adequate, it is clear that the upper section of the well has higher discriminant score values than the lower. Thus, the previously identified lithologies on the MN plot are proved by a direct link with the exactly known borecores of Well-Q.

\subsection{Separation and boundary estimation between graphitic carbonate phyllite and mylonitic lithologies}

Second, look at the wells that, according to the cuttings, explore the graphitic carbonate phyllite lithology. In Well-R, all the porosity logs are available and the upper section of the explored rock column belongs to the graphitic carbonate phyllite. The cross plots of the porosity measurements of the well show two slightly separate groups, presented on the density-neutron plot (Fig. IV.7/a). The graphitic carbonate phyllite values have a higher standard deviation in the neutron measurements, compared to the remaining "some gneiss" section. On the gamma-resistivity plot (Fig. $I V .7 / b)$ the extremely low resistivity values of the graphitic carbonate phyllite are conspicuous. Furthermore, its gamma measurements clearly show lower values than those characteristic of the "some gneiss" unit. Well-S has some graphitic carbonate phyllite and graphitic gneiss mylonite borecores, but does not have any porosity logs. Its gamma-resistivity plot shows a rather similar sight to the case of Well-R (Fig. IV.7/b); the borecores of graphitic carbonate phyllite appear with high standard deviation in the low resistivity field, while the mylonitic borecores and the remaining intervals of the well have higher resistivity and gamma values.

On the MN plot, the known graphitic carbonate phyllite and the remaining values are aligned with the lower side $(\mathrm{A}-\mathrm{S})$ of the anhydrite $(\mathrm{A})$ - sandstone $(\mathrm{S})$ - limestone $(\mathrm{L})-$ dolomite (D) quadrangle. This position, according to the orthogneiss vs. mylonite MN plots (Fig. IV.3/b, Fig. IV. 4/c), suggests that the "some gneiss" lithology in this well should be the mylonitic lithology. The gamma-resistivity plot of Well-S is also confirmed. 


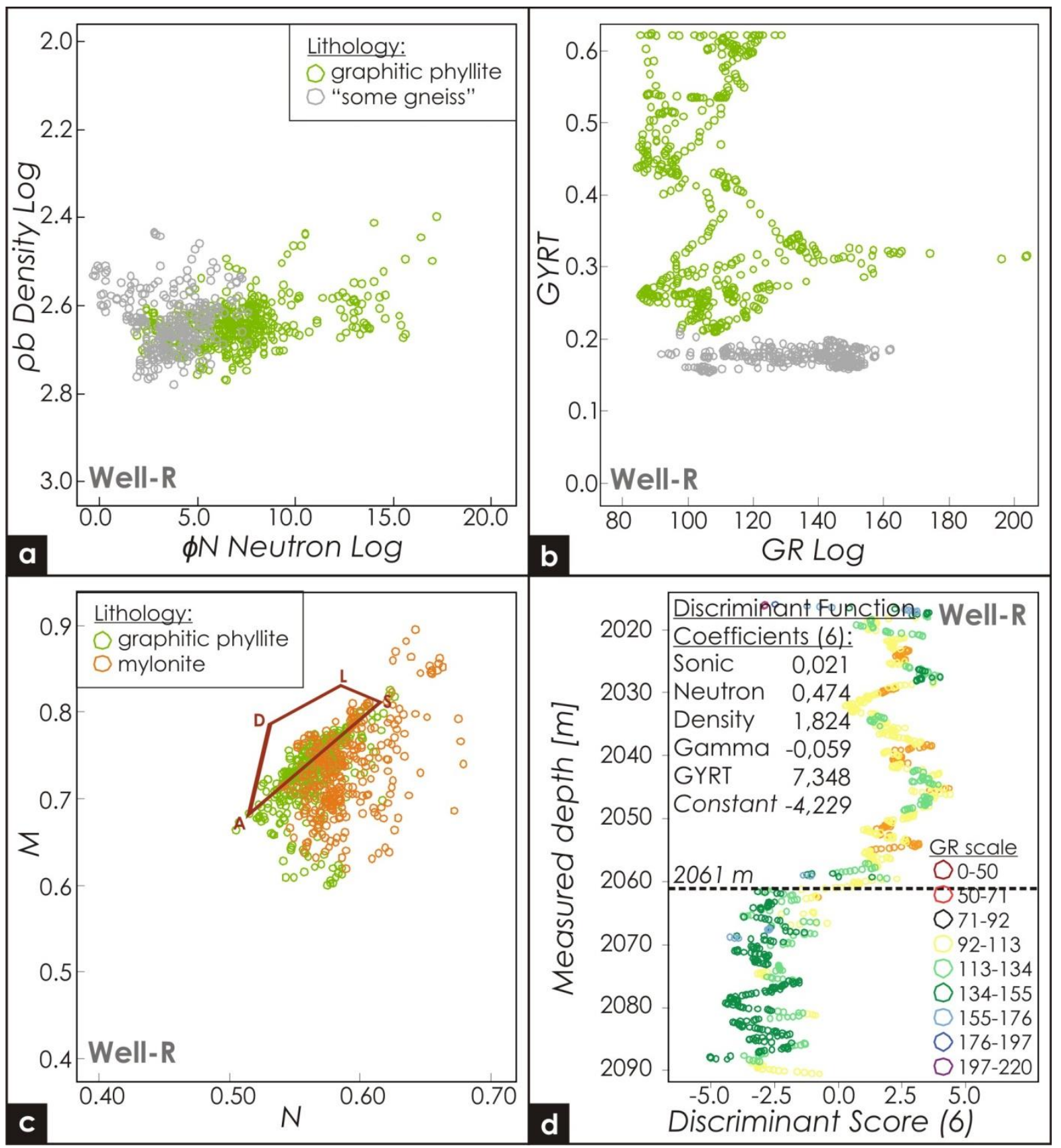

Figure IV.7. The a) neutron-density, the b) gamma-resistivity and the c) MN plot of the well-R; d) results of the discriminant function analysis (D6) for graphitic carbonate phyllite and mylonite in the well-R.

Legend: $A$ - anhydrite, $S$-sandstone, L-limestone, $D$-dolomite.

Discriminant function analysis was fulfilled for these two lithologies (graphitic carbonate phyllite and mylonite) on Well-R. The result shows a fairly good separation (Fig. $I V .7 / d)$, using the function of:

$\mathrm{D}(6)=(0.021 * \mathrm{~S}+0.474 * \mathrm{~N}+1.824 * \mathrm{D}+7.348 * \mathrm{R})-(0.059 * \mathrm{G}+4.229)$. 
Besides, the resistivity (R), the density (D) and neutron (N) measurements have the main role in the separation, while the sonic (S) and the gamma $(\mathrm{G}) \operatorname{logs}$ are subordinate. The boundary between the two rock units is estimated at $2061 \mathrm{~m}$. This depth coincides well with the noted boundary in the drilling documentation. As none of the other wells that contain graphitic carbonate phyllite have porosity logs, further application of the $\mathrm{D}(6)$ function is not possible.

\subsection{Spatial extension of the estimated lithology boundaries}

There is insufficient data to construct an entire 3D rockwork model for the whole study area; nevertheless, along certain geological sections it is possible to extend information in 2D. Neighbouring wells were used with a mylonite/gneiss boundary along two lines, which pass through the field (Figs. IV.8, IV.9). These sections could provide information about the structural build-up of the area. In the course of the interpretation of the sections we took into consideration the ten known hydraulic regimes in the field (unpublished industry report, Fig. $I V .8)$. Within each regime, all wells communicate with each other, but have no hydraulic connectivity with any other well outside that sub-area. Such communication among the wells might be in relation to the structural geometry of the field. As common examples, impermeable fault zones or even unfractured rock masses may define regime boundaries.

Along the $\mathrm{AB}$ section (Fig. IV.9) the two regime boundaries could be interpreted as normal faults with a southern dip. The mylonite/gneiss boundaries inside all the three regimes have a very similar, moderate northern dip. Along the AC section (Fig. IV.9) one of the regime boundaries could be interpreted as a normal fault (as in the case of the AB section); the mylonite/gneiss boundaries inside both separated blocks have a moderate northern dip as well. Inside the northern block along the AC section, three independent hydraulic regimes exist (Fig. IV.8), but there is no indication of the presence of additional normal faults. Consequently, there should be another factor responsible for separation inside the hydraulic system. Although the well-logs record it as a homogenous block, it is known from the previous petrological studies that the mylonite is petrologically extremely heterogeneous. The two different mylonite types exhibit different reservoir features; so the orthogneiss mylonite samples have a small amount of natural fractures and, according to the previous rock mechanical tests (Nagy et al. 2013), this block is characterized by moderate anisotropy and tendency to fracture. In this body, formation of a complicated and connected fracture system is unlikely. The graphitic gneiss mylonite block contains strongly fractured, locally brecciated, and oil spotted borecore samples. Rock mechanical tests pointed out that a 
possible communicating fracture system can be achieved by much lower work investment than for other lithologies. Furthermore, these tests clearly indicate that the orientation of the mylonitic foliation also has a significant influence on the reservoir features; the graphitic gneiss mylonite samples show high anisotropy depending on the sample orientation in the compressive test. A remarkable difference can be computed between the samples tested parallel and perpendicular to the preserved foliation of the rock (Nagy et al. 2013). Therefore, we could assume that, in addition to post-metamorphic, impermeable fault zones also change in petrographic characteristics and that orientation of the main structures inside the lithology blocks determines the hydraulic behaviour of the field.

The eminent role of the mylonite zone in the behaviour of the whole fractured reservoir is also proved by the positions of hydrocarbon productive intervals. As is indicated in Figure $I V .9$, in each case where a restricted productive interval can be localized, the hydrocarbon production clearly comes from the mylonitized zone. In the other cases, the perforation covered a significant interval of the wells involving also the lowermost orthogneiss. In fact, almost the whole depth of these wells is open for fluid flow and there is no way to point the most productive intervals. Nevertheless, also keeping in mind the rock mechanical data, one can suppose that the main productive zones, even in these cases, can be linked to mylonitic horizons. The overlying Miocene limestone is also productive for hydrocarbon in certain wells, clearly proving hydrodynamic communication between the fractured basement reservoir and the sedimentary cover.

Inside each fault-bounded regime, the orientation (dip and dip angle) of the mylonite/gneiss boundary surface could be calculated, if more than two data points exist. According to three independent calculations, this dip direction is rather consequent, being north-northeast $\left(13^{\circ}-18^{\circ}\right)$, and the angle is systematically less than $5^{\circ}$. So the investigated KIHA-NE area is characterized by a shallow-dipping extensional mylonite zone. This wide zone separates blocks of systematically different metamorphic evolution and peak conditions. Formation of such a shear zone is typical when metamorphic core complexes develop during continental extension along low-angle $\left(<30^{\circ}\right)$ detachment faults (Lister \& Davis 1989). Mylonitic gneiss formation at several-kilometre depths along major shallow-dipping ductile shear zones is linked to activity of these detachment faults. The detachment faults usually form at the beginning of the extension process; however, they do not remain active throughout the entire geological history of the metamorphic core complex (Lister \& Davis 1989). Later, when these mylonitized zones uplift and deform in the brittle deformation zone, they may be 
overprinted by cataclasis of brecciation (Lister \& Davis 1989) or even become fragmented along normal faults of younger tectonic movements.

Figure IV.8. KIHA-NE wells situated on the metamorphic topography, with the ten hydraulic regimes and the lines of the geological sections of Figure 9.

Legend:

1 - counter lines of the metamorphic basement depth,

2 - hydraulic regime,

3 -well spot inside the reservoir,

4 -well spot outside the reservoir,

5 - lines of the geological sections.
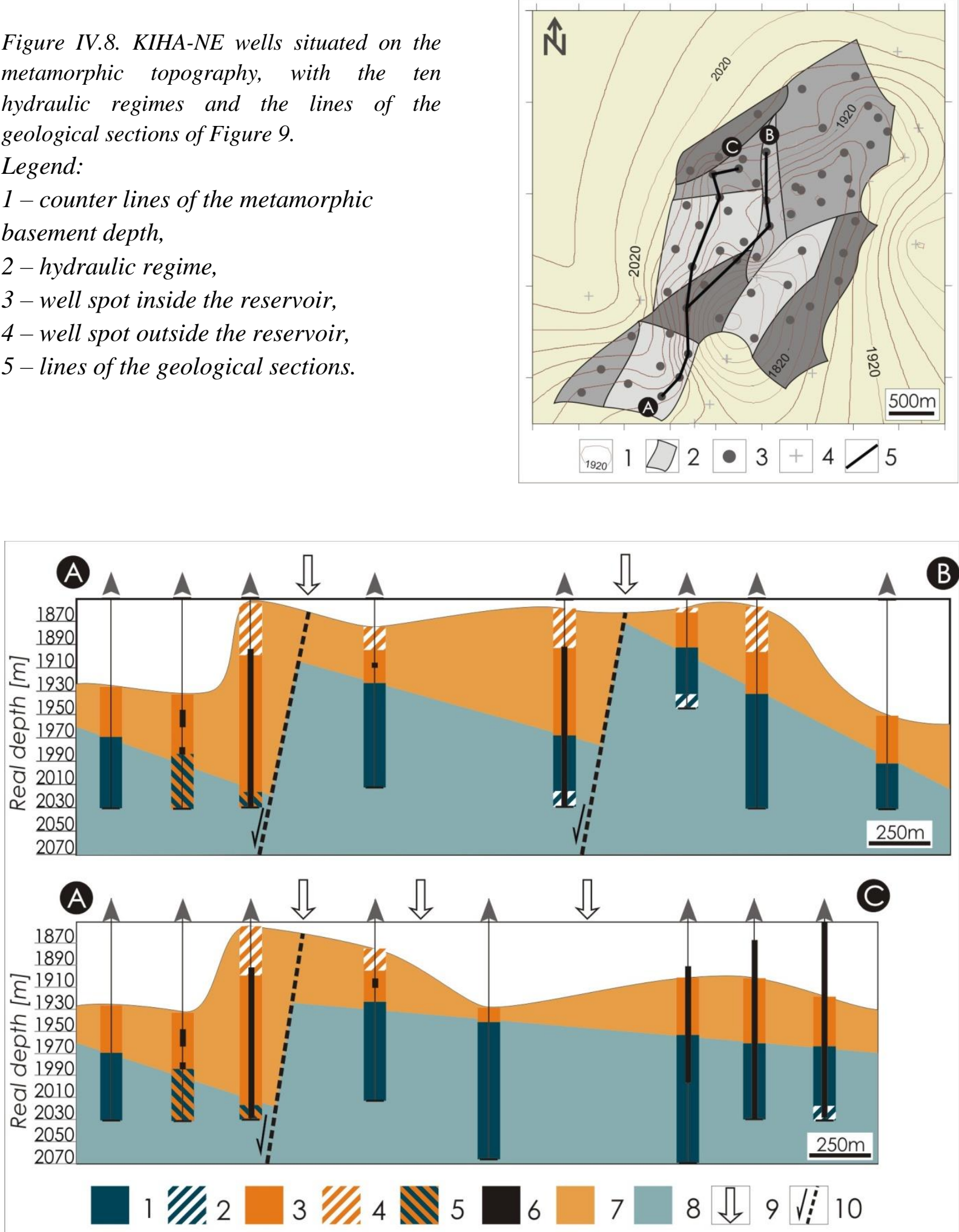

Figure IV.9. Geological sections through the field.

Legend: 1 - mylonite, 2 - probably mylonite, 3 -orthogneiss, 4 - probably orthogneiss, 5 „some gneiss” (mylonite or gneiss) $6-\mathrm{CH}$ productive interval along the well; estimated 7 mylonite or 8 - orthogneiss body; 9 - hydraulic regime boundary, 10 - assumed normal fault. 


\section{Summary}

On the basis of well-log data, basic lithologies of the KIHA-NE metamorphic basement high can be distinguished; we can separate orthogneiss from mylonite and mylonite from graphitic carbonate phyllite by using conventional plots (especially the MN plot) and a statistical approach (discriminant function analysis). In the separation algorithms, the density and resistivity $\operatorname{logs}$ have a major role. The lithologically different mylonitized rock types cannot be separated by these methods.

In the course of the spatial extension of the results, spatial positions of the independent hydraulic regimes can also be taken into account. On the resultant geological sections, several south-dipping normal fault-bounded blocks are assumed, which clearly record shallowdipping mylonite/gneiss boundaries with a north-northeast dip direction. Existence of this low-angle mylonitized zone refers to the presence of a one-time detachment fault linked to the formation of a metamorphic core complex. Based on this structural image, the spatial position of the mylonite zone can be extended for the whole area. As mylonite is the only basement lithology that serves remarkable fractured porosity, the spatial model may contribute significantly to producing more accurate reservoir models. 


\section{Chapter V.}

\section{CONCLUSIONS}

\section{Summary of the results}

At the starting point of the present study of the KIHA-NE hydrocarbon field, it was only known that various rock types - gneiss, micaschist, amphibolite, different mylonitic types, migmatite, and a low-grade phyllite (T. Kovács 1973, Árkai 1978, Cserepes 1980, T. Kovács and Kurucz 1984, Cserepes-Meszéna 1986, Árkai 1993) - constitute the basement in an unknown structural build-up. The whole area was handled as a unified rock body in the reservoir models.

In the course of the present study, four main rock types were identified (orthogneiss, orthogneiss mylonite, graphitic gneiss mylonite, graphitic carbonate phyllite; Chapter II.) in the KIHA-NE metamorphic basement, characterised by significantly different metamorphic and tectonic evolutions. In order to compare the reservoir features of the three prevalent rock types (orthogneiss, orthogneiss mylonite, graphitic gneiss mylonite), rock mechanical tests and CT images were evaluated; also with regard to the foliation and the stress field relationship. On the basis of the results it can be stated that the petrologically different rock types have remarkably different brittle behaviours. In this way the hypothetically best reservoir lithology of the field could be recognised, and its favourable features (Chapter III.). By the usage of open-hole well-log datasets it was possible to extend the point like information of the borecores and sketch a spatial image detailing the geometry and extent of the best reservoir rock units, and the structural build-up of the whole field (Chapter IV.). The remainder of this section outlines the obtained results (Fig. V.1).

In the lowest structural position orthogneiss is common, which according to its petrographic features $(\mathrm{fsp}+\mathrm{qz}+\mathrm{bt}+\mathrm{mu} \pm \mathrm{chl}$ mineral assemblage, myrmekitic feldspars, amphibolite xenocrysts and xenoliths; Chapter II.4.1) is assumed to be identical to the orthogneiss body of the adjacent Jánoshalma basement high (metamorphic peak temperature $T$ $<580{ }^{\circ} \mathrm{C}$ according to Zachar and M. Tóth 2004). On the samples a few narrow fractures are present, with carbonate infill and narrow alteration zone. There is no oil spotted sample which should refer to petroleum migration along the explored borecores. The standard unconfirmed compressive tests created only a small number of fractures (cumulative fracture length varies around 9) with poor connection (with a fractal dimension of around 1.3) by relatively high invested work $\left(\mathrm{W}_{\mathrm{d}}\right)$ (Table III. 1); thus orthogneiss is obviously not the best reservoir 
lithology in the field (Fig. V.1). In the parameter space of all rock mechanical variables, the data points of the orthogneiss appear separately (Fig. III.9b) but close to the orthogneiss mylonite samples (Fig. III.9d), and so the two clusters can be distinguished. Orthogneiss can be separated from the mylonite types on the open-hole well-logs, by using conventional plots (especially the MN plot) and a statistical approach (discriminant function analysis) (Fig. IV.34). In the separation algorithms, the density and resistivity logs have a major role.
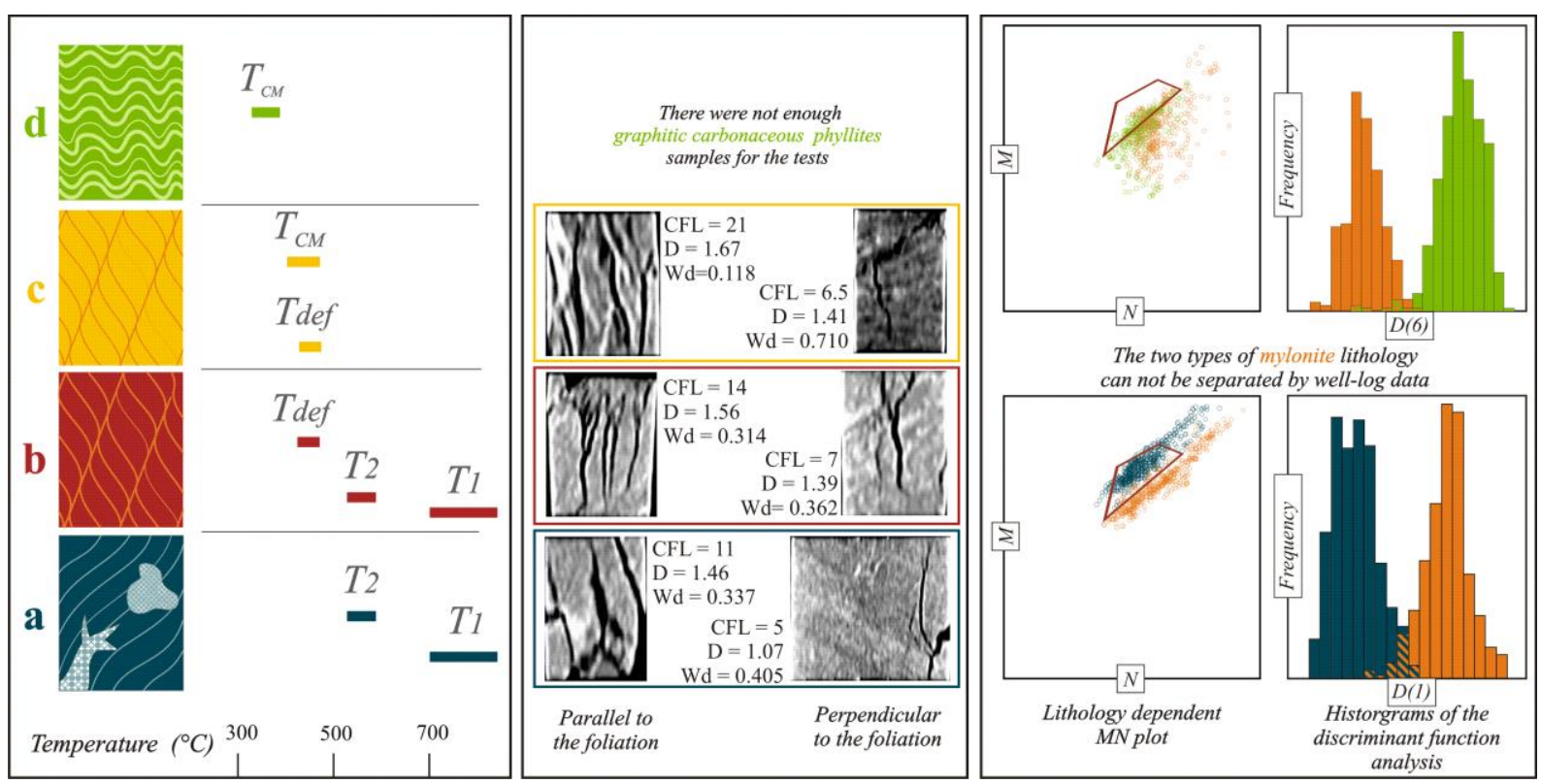

Fig. V.1. Summary of the result for the Kiskunhalas-NE field

The next rock unit upward is the highly mylonitized variety of orthogneiss on the basis of the similar mineral assemblages of the two rock types (Chapter II.4.4). The samples are usually moderately fractured, with thin veins filled with carbonate minerals, and locally enclose fragments of the host rock. According to the rock mechanical tests, the orthogneiss mylonite is characterised by moderate anisotropy and fracture tendency. The fractal dimension and cumulative fracture length values do not suggest the possibility for formation of complicated and connected fracture systems.

In the higher section of the sheared zone another type of mylonite is present; its mineral assemblage is consequently different from the lower orthogneiss mylonite (presence of graphite and pyrite as index minerals; Chap. II.4.5). The graphitic gneiss mylonite can be characterised with a peak metamorphic $T$ of $410 \pm 45^{\circ} \mathrm{C}$ (carbonaceous material thermometer by Raman microspectroscopy; using the methods of Beyssac et al. 2002, Rahl et al. 2005, Aoya et al. 2010; Fig. II. 3). The graphitic gneiss mylonite has the most fractured samples in the field, some samples are completely brecciated. A few centimetre large cavities (vuggy fractures) are frequently present in the cores, and they are commonly oil spotted. In the 
parameter space of all rock mechanical variables, the data points of the graphitic gneiss mylonite appear clearly separated from both the orthogneiss and its mylonitic variety (Fig. III.9d). High anisotropy (Fig. III.9c) and a large and possibly communicating fracture system characterise this lithology unit, achieved by a much lower work investment than for any other rock type of the field.

The mylonite zone, consists of two petrologically different rock types; both are characterised by mylonitic foliation (C/S structure, Fig II.2g, j), quartz ribbons and lenses deformed in ductile mode (strongly serrate grain boundaries, undulose extinction, deformation lamellae), and textural markers of bookshelf structure (Fig. II.2h), microboudinage (Fig. II.2l), and mica fish. Estimation of the deformation temperature for both mylonitic rocks results in approximately $T_{d e f} \sim 455^{\circ} \mathrm{C}$ (sutured quartz grain thermometer by Kruhl and Nega 1996; Fig. II.5). The lithologically different mylonitized rock types cannot be separated by the open-hole well-log datasets (Fig. IV.3b).

The lithology in the shallowest structural position of the area is a graphitic carbonate phyllite, with a $T$ of $375 \pm 15{ }^{\circ} \mathrm{C}$ (carbonaceous material thermometer by Raman microspectroscopy using the methods of Beyssac et al. 2002, Rahl et al. 2005, Aoya et al. 2010; Fig. II.3). There was not enough sample for the rock mechanical test, although this is a subordinate rock type in the KIHA-NE area, possibly due to its uppermost position in the ideal rock column. Most probably it had been exhumed at the surface for a long time, as is indicated by surface weathering of the graphitic carbonate phyllite (proved by Árkai, 1991). Using open-hole well-logs one can separate mylonite from graphitic carbonate phyllite by conventional plots (especially the MN plot, Fig. IV.7c) and statistical approach (discriminant function analysis Fig. $I V .7 d$ ).

On the basis of all these results, an ideal rock column is manifested with rock units of incompatible metamorphic evolutions (Fig. II.O) and significantly different reservoir features (Fig. III.9). Nearly $200{ }^{\circ} \mathrm{C}$ metamorphic temperature deviation exists between the top (graphitic carbonate phyllite) and the bottom (orthogneiss) units; it is probable that the two extreme blocks got juxtaposed along a shear zone in the basement at approximately $15 \mathrm{~km}$ depth (Fig. II.7). The estimated lithology boundaries can be represented along geological sections (Fig. IV.9), where shallow dipping mylonite/gneiss boundaries with northnortheastern dip direction become clear. Although the mylonitised zone shows textural markers clearly developed in the extensional stress field, the direction of the maximum extension of the rock body cannot exactly be defined. The natural strain will practically always be inhomogeneous at most scales of observation, but it may be considered 
homogeneous in small volumes of fine-grained rock, for example, at the scale of a thin section (Passchier and Trouw 2005). Although investigations of macrostructures in an outcrop should provide unequivocal evidence for the stress field character of a shear zone (e.g., extensional, compressional), such a judgement seems to be impossible under small scale circumstances. After the current sequence of the lithologies was formed, the entire rock column exhumed to a shallower position and deformed in a brittle way during the next stages of the tectonic development. The different lithology types did not fracture to the same extent because of their different rheological features. These dissimilarities have a significant influence on the reservoir features. In the course of further structural evolution, normal faults fragmented the rock body. As is presented in Fig. IV.9, these normal faults can probably define hydraulical regime boundaries in certain cases, so behave as impermeable faults. Nevertheless, the hydraulical regime boundaries may also be influenced by the petrological differences inside the mylonite zone, and the relative orientations of its foliation and the stress field, because of the highly anisotropic behaviour of the graphitic gneiss mylonite. This effect could cause presence of the hydraulical regime boundaries e.g. in the northern part of section AC (Fig. $I V .9)$.

In summary, it can be stated that these new results contribute significantly to the understanding of basic geological circumstances, petrological characteristics and structural build-up of the metamorphic basement in the Kiskunhalas region. The new models may also assist applied geological progress, especially in reservoir modelling and field development. Considering the new results, one can conclude that when re-interpreting old hydrocarbon reservoirs, even a lack of essential geological data can be handled by integrated data management. Practically in cases where there is only old and poor data and information available from the investigated area (borecore samples, thin sections, drilling documentation, first examination and documentations of the borecores, ancient well-logs, industrial reports), a maximized and harmonized application of all available is required. This kind of complex view and the application of a wide spectrum of methods applied in the course of the present study (standard routine of the integrated core study with petrology, rock mechanical test and CT image analysis; the available open-hole well-log usage for lithology identification) should be used in the future in similarly favoured areas. 


\section{Outlook}

There are several localities in the basement of the Pannonian Basin where incompatible metamorphic rocks constitute the ideal rock column (e.g., Baksa Complex - Nagy and M. Tóth 2009, Mezősas-Furta - M. Tóth and Zachar 2006, Jánoshalma - Zachar and M. Tóth 2004, Dorozsma - M. Tóth et al. 2002, Kiskunhalas - Nagy and M. Tóth 2012). Orthogneiss varieties are the most widespread rock types in the basement (Szepesházy 1973), nevertheless their mineral assemblage and metamorphic evolution can vary on a wide scale. In several orthogneiss bodies, xenoliths and lenses of metabasic composition (e.g. amphibolite) are common (e.g.: Kiskunhalas - Nagy and M. Tóth 2012; Kömpöc - Csólyos-K - Nagy and M. Tóth 2012; Jánoshalma - Zachar and M. Tóth 2004, Mezősas-Furta - M. Tóth and Zachar 2006) and xenoliths of exotic compositions are also present, for example eclogite in Jánoshalma Dome (Zachar et al. 2007), and actinolite schist and serpentinite in Mezősas-Furta (Zachar and M. Tóth 2006). In the case of Jánoshalma, Zachar and M. Tóth (2004) have suggested an accretionaly prism origin of these xenoliths.

In numerous fields the incompatible rock column is accompanied by sheared lithologies (e.g., Mezősas-Furta - M. Tóth and Zachar 2006, Szeghalom - Schubert and M. Tóth 2001, Jánoshalma - Zachar and M. Tóth 2004, Dorozsma - M. Tóth et al. 2002, Kiskunhalas Nagy and M. Tóth 2012), suggesting that the current order of rock units was created by postmetamorphic tectonic movements. Along a shear zone the character of the deformation varies with the depth; mylonite can form in the deeper regions, while cataclasite and fault breccia form in the upper region of the crust. In the basement of the Pannonian Basin both wide mylonite (Kiskunhalas, Nagy and M. Tóth 2012) and cataclasite (Szeghalom, e.g., Molnár et al. 2013) zones exist. In certain cases a brittle deformation event can overprint the previous ductile one, such as in the Kömpöc - Csólyos-K area (Nagy and M. Tóth 2012). In some localities gouge is also an important part of the shear zones (Molnár et al. 2013). Unfortunately, just a little information and data is available in publications and industrial reports about the physical condition and ages of these shear zones and there is no clear theory about the structural evolution of these horizons; rather, there are many contradictory hypotheses (e.g., Lelkes-Felvári et al. 2005, Balogh et al. 2009, M. Tóth 2013).

After the Variscan ages there were several optional large scale tectonic events, which might have caused the development of the fault related rocks in the basement. The first detected metamorphic events of these orthogneiss happened during the Variscan orogeny (e.g., Szederkényi 1996, Kovács et al. 2000, Balogh et al., 2009), although the age constraints 
regarding the detailed metamorphic evolution is still rather limited. There are numerous 330 Ma and junger Variscan ages relating to different states of the complicated metamorphic history (e.g., Szederkényi et al. 1991, Lelkes-Felvári et al 2003, 2005, Balogh et al. 2009). Regarding the Variscan uplift and the synchronous shear events only very poor data is available. In Szeghalom, a deformation age of the Permian (280.2 \pm 10.5 Ma from mylonitic white mica, K/Ar age) is documented (M. Tóth 2013). In the Dorozsma basement, Dunkl (1994) provides an Early Triassic FT age, which refers to the age of its post-metamorphic uplift.

The effect of the Jurassic continental rifting (Haas and Péró 2004) caused, for example, the coal formation of the Mecsek Mountains in half graben structures; this large scale extension event may have had a relationship with the Jurassic (186.9 \pm 7.1 Ma feldspar K/Ar age; $160.2 \pm 8.7 \mathrm{Ma}$ zircon FT age) ages in the sheared metamorphic basement mentioned by Balogh et al. (2009).

In the course of the Alpine orogeny (Cretaceous and younger) north vergent nappes (e.g., Codru nappe system) and slices formed inside the Tisza Unit (e.g., Rozlozsnik 1936,

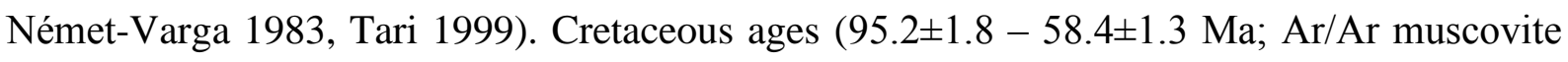
ages; Lelkes-Felvári et al. 2005) were measured, among many others in metamorphic rocks of the Algyő complex.

The Miocene back-arc basin extension related to the Alpine orogeny (Hajnal et al. 1996) generated a number of uplifted and tilted blocks and a set of pull-apart basins (Tari et al. 1992). Seismic measurements suggest uplifted metamorphic highs interpreted as metamorphic core complexes (Horváth et al. 2006). A series of subhorizontal reflections were detected in the basement around Szeghalom, related to this rather quick uplift (Posgay et al. 2006).

All these tectonic events may have caused wide tectonic zones (either mylonitic or cataclastic) and contributed to the development of the juxtaposed block with different metamorphic evolutions and ages inside the metamorphic basement. The resulting mosaic structure of the basement essentially determines its capacity in fluid migration and/or storage. So, the characteristic petrologic heterogeneity of the basement highs can determine the storage volume geometry, since the different rock types have different tendencies to create a connected fracture system. Previous studies suggest that orthogneiss has not proved to be a good reservoir, while its mafic xenoliths (e.g., Schubert and M. Tóth 2003, M. Tóth et al. 2004) or the mylonites (e.g., in Kiskunhalas) frequently show quite good production zones. In fact the role of the shear and fault zones may be various, since they can behave both as 
permeable and impermeable zones (e.g., Szeghalom, Molnár et al., 2013) and may also act as migration pathways and/or storage bodies (e.g., Kiskunhalas - Nagy et al. 2013).

In the future, significant scientific effort should be put into deep understanding of the structure and evolution of the numerous and different shear zones inside the metamorphic basement of the Pannonian Basin. Considering our current knowledge, these horizons are of key importance concerning both the basic and applied geological point of view. 


\section{SUMMARY}

\section{Background}

The crystalline basement of the Great Plain of Hungary has provided an interesting research topic for decades; its basic and also applied research aspects are multiple. Although industrial interest largely determines its exploration, samples and geophysical data obtained in this way could give a good insight into the geology of the area.

The Kiskunhalas-NE hydrocarbon field has been produced since the mid-1970s. In this area more than one reservoir block exists; there is a northern reservoir with a Palaeozoic metamorphic basement and a southern one with a Mesozoic carbonate basement. The reserving formations from different ages and material (Palaeozoic metamorphic rocks, Mesozoic carbonates and Miocene sediments) in certain cases behave as one hydraulic regime. The focus of the present study is the reservoir with the metamorphic basement. Several different publications (T. Kovács 1973, Árkai 1978, Cserepes 1980, T. Kovács and Kurucz 1984, Cserepes-Meszéna 1986, Árkai 1993) and unpublished industrial reports have noted several rock types in the crystalline basement (gneiss, micaschist, amphibolite, different mylonitic types, migmatite, and a low-grade phyllite); however, in interpreting the reservoir the whole area has been handled as a homogeneous block. Actually, the KIHA-NE reservoir has a highly compartmentalized nature, since there are at least ten independent hydraulic regimes in the field.

On the one hand, this present study is situated within basic geological research. A review on any hydrocarbon field is necessary from time to time because new methods and novel scientific theories can enrich existing knowledge about the narrowly studied fields and their wider geological environment. In this way it will be possible to enrich the highly sporadic information about the crystalline basement of the Pannonian Basin in the wider neighbourhood of the study area.

On the other hand, this research also has an applied geological point of view. Newly acquired knowledge about the field provides more adequate framework about the characteristics of the reservoir. It can help to create a better reservoir model which can contribute to more effective production, and which can provide guidance about field development processes, even regarding the drilling of new wells. The new methods, data management or the routine of test series learned or developed in the course of this project 
could be utilized in the future. The official review of the Kiskunhalas fields in the MOL Plc., begun in 2008, provides actuality for this research. In the wider environment (around Jánoshalma and Kiskunhalas) the RAG (Rohöl-Aufsuchungs Aktiengesellschaft) currently conducts research.

\section{Methods applied}

For the purpose of the identification and classification of the lithology units of the field, and to give a detailed petrographic and textural description, macroscopic and microscopic examination and prudent microtexture analyses were carried out. In the course of the pertographic study, the available core samples of 15 wells and more than 100 thin sections were investigated.

Thermometric examinations were also carried out on the samples to clarify the genetic relations between the rock units. The sutured quartz grain boundaries of the mylonitised lithologies were used for the deformation-related thermometer of Kruhl and Nega (1996). On the calibrated textural thermometer a linear function is suggested between the fractal dimension of the sutured quartz grain boundaries and the formation temperature. Two lithologies of the field contained representative amounts of carbonaceous material that allowed the possibility of using the carbonaceous material thermometer using Raman microspectroscopy (Beyssac et al. 2002, Rahl et al. 2005, Aoya et al. 2010). The method is based on the irreversible and temperature dependent character of the graphitisation process. The resulting temperature estimate is the maximum temperature the rock reached along a given PT path.

On the representative samples, destructive and non-destructive rock mechanical treatment and a 3-dimensional scan with X-ray Computed Tomography (CT) were fulfilled, parallel and perpendicular to the foliation. In this way the fracture tendency and the brittle behaviour of the petrologically different rock types were estimated. The amount (cumulated fracture length) and the geometry (fractal dimension) of the provoked fracture system determine the reservoir features of the lithologies.

For spatial extension of the point such as geological information along the wells, datasets of over a decade old digitalised open-hole well-logs (gamma, resistivity, neutron, density, and acoustic $\operatorname{logs}$ ) were used. For lithology identification and lithology boundary estimation conventional cross plots, lithology sensitive MN plot (Schlumberger, 1989) and discriminant 
analysis were carried out. The estimated lithology boundaries were represented along geological sections to explore the geometry and the structural build-up of the field.

\section{New scientific results}

The following new scientific results have emerged in the course of these investigations:

1.) In the Kiskunhalas-NE field, four main rock units were identified. On the basis of neighbourhood relations, these types define the following ideal rock column from the bottom upwards: orthogneiss, orthogneiss mylonite, graphitic gneiss mylonite and graphitic carbonate phyllite.

2.) The deepest known formation is an orthogneiss body with amphibolite xenoliths and micapoor granitic dykes. According to its mineral assemblage and relict igneous textures (mirmekite, idiomorphic zircons) one can assume that it is identical to the neighbouring Jánoshalma orthogneiss characterised by $T<580{ }^{\circ} \mathrm{C}$ metamorphic temperature. Because of the similar mineral assemblages and the presence of the relict igneous textures, this orthogneiss might be the protolith of the orthogneiss mylonite following the orthogneiss upwards.

3.) The other lithology type of the mylonitised zone, the graphitic gneiss mylonite, is clearly different from the orthogneiss based on its index minerals (graphite, pyrite). It is also different from the uppermost graphitic carbonate phyllite because of the high quartz+feldspar+sericite content of the graphitic gneiss mylonite; its undeformed protolith is unknown in the field. The Raman microspectroscopy based carbonaceous material thermometer result for this lithology is $T=410 \pm 45^{\circ} \mathrm{C}$.

4.) The uppermost structural position, characterised by graphitic carbonate phyllite, has a subordinate role in the field. It consists of chaotically folded light (carbonate+sericite+some quartz) and dark (graphite, pyrite, clay minerals) bands. The Raman microspectroscopy based carbonaceous material thermometer result for this lithology is $T=375 \pm 15^{\circ} \mathrm{C}$.

5.) The mylonitised zone, constituting a significant part of the rock mass, is built-up by two petrologically different lithologies, uniformly bearing textural elements (bookshelf structure, microboudinage, mica fish) developed in an extensional stress field on a micro scale. The sutured quartz thermometer results of both mylonitised lithologies give around $T_{\text {def }} \sim 455^{\circ} \mathrm{C}$. 
6.) Along the incompatible rock column, nearly $200{ }^{\circ} \mathrm{C}$ metamorphic peak temperature difference exists. The $T_{d e f} \sim 455^{\circ} \mathrm{C}$ value for the mylonitised zone could mean a shear zone was active at approximately $15 \mathrm{~km}$ depth, depending on the geothermic gradient. The recent order of the rock units might have developed in the course of this post-metamorphic tectonic event. Although the presence of extensional textural markers in the mylonite zone do not preclude a compressional stress field in respect of the whole rock body, the possibility of a shear zone in the extensional stress field is more likely.

7.) On the basis of the rock mechanical investigations, the reservoir features of three predominant rock types in the area (orthogneiss, orthogneiss mylonite, graphitic gneiss mylonite) are significantly different. The graphitic gneiss mylonite has the best reservoir features, as it tends to have a large and connecting fracture network, achieved by lower invested work relative to the other lithologies. A characteristic feature of each measured parameter is the high anisotropy. The samples crushed parallel to the mylonitic foliation have much more favourable properties from the reservoir point of view, than the samples crushed perpendicular to the mylonitic foliation.

8.) With the available open-hole well-log datasets, the orthogneiss and mylonite lithologies could be separated along the given wells; the resistivity and the density logs have a major role in the separation. The mylonite and the graphitic carbonate phyllite zones could also be separated. Nevertheless, the two petrologically different mylonite lithologies (orthogneiss mylonite, graphitic gneiss mylonite) could not be separated on the available open-hole well-logs. In this way, three rock units were identified (orthogneiss, mylonite, graphitic carbonate phyllite), and the lithology boundaries were estimated between them along the wells.

9.) The estimated lithology boundaries were represented along geological sections. The gneiss/mylonite boundaries appear as a low angle $\left(<5^{\circ}\right)$ plane with northern dip $\left(13-18^{\circ}\right)$; interpreted as a onetime detachment fault linked to a formation of a core complex if it worked in the extensional stress field.

10.) Also taking into consideration the hydraulic regimes of the field, several normal faults of a later brittle deformation event could be identified. These normal faults behave as impermeable faults between the productive mylonitised bodies. Nevertheless, the presence of some regime boundaries should be the result of the petrological diversity of the mylonite zone, which also means rock bodies with different fracture tendency. The high anisotropy of the mylonite lithologies further modifies the reservoir body geometry. 


\section{ÖSSZEGZÉS}

\section{Előzmények}

Az Alföld kristályos aljzatának fejlődése, felépítése évtizedek óta izgalmas kutatási téma, melynek mind alap-, mind alkalmazott kutatási vonatkozásai igen sokrétủek. Habár a feltártságot nagyban meghatározza az ipari érdeklődés, az így nyert minták és adatok jó betekintést engednek az adott terület földtanába.

A Kiskunhalas-ÉK szénhidrogén rezervoárt az 1970-es évek közepe óta termelik. Két mezőre osztható, egy kristályos aljzatú északi és egy karbonátos aljzatú déli mezőre; jelen kutatás tárgya az északi. A különböző tudományos közlemények (T. Kovács 1973, Árkai 1978, Cserepes 1980, T. Kovács és Kurucz 1984, Cserepes-Meszéna 1986, Árkai 1993) és nem publikált ipari jelentések számos kőzettípust leírtak a területen: gneisz, csillámpala, amfibolit, különböző milonit típusok, migmatit, és kis metamorf fokú fillit. Ennek ellenére az aljzati tárolót a modellekben rezervoárgeológiai értelemben egységesnek kezelik, habár a mezőn belül legalább tíz hidraulikai rezsimet különítenek el.

A kutatás célja egyrészt alapkutatási jellegü, mivel az egyes területek időről időre történő újra vizsgálata, új módszerekkel vagy új elméletek szempontjából, gazdagíthatja az általános földtani ismereteket a szükebb (Jánoshalma, Tázlár) és tágabb (Tisza Egység aljzata) földtani környezetben. Másrészt alkalmazott föltani kérdéseket is célunk megválaszolni, mivel a kutatási terület egy aktív, szénhidrogén termelö mező. Az újonnan nyert ismeretek segíthetik a rezervoár jobb megértését, annak további művelését, fejlesztését. A kutatás során megismert és/vagy kidolgozott módszerek, adatkezelési eljárás, integrált vizsgálat sorozat más, hasonló területeken is alkalmazhatóak lehetnek. Különös aktualitást ad a kutatásnak, hogy 2008-ban indult el a terület reambulációja a MOL-csoportban; illetve hogy a környéken (Jánoshalma, Kiskunhalas) a Rohöl-Aufsuchungs Aktiengesellschaft (RAG) jelenleg is új termelési lehetőségek után kutat.

\section{Alkalmazott módszerek}

A területen előforduló kőzettípusok azonosítása és osztályozása érdekében makroszkópos és mikroszkópos vizsgálatokat végeztünk, 15 kútban rendelkezésre álló fúrómagokon és több mint 100 vékony csiszolaton. A nyírt kőzetek jelenléte miatt alapos 
mikroszöveti megfigyeléseket is végeztünk. A meghatározott litológiai egységek részletes petrográfiai és szöveti leírása a további vizsgálatok alapját képezték.

A megismert kőzettípusok genetikai viszonyainak tisztázása érdekében termometriai módszereket alkalmaztunk. A milonitosodott litológiákban szuturált szemcsehatárú kvarc szemcsehalmazokon Kruhl és Nega (1996) deformációval összefüggő termométerét használtuk. Ez a szöveti termométer a szemcsehatár geometriája (fraktál dimenzió érték) és az azt létrehozó hőmérséklet közti lineáris kapcsolatot használja ki a hőmérséklet becslésére.

Mivel két kőzettípus is tartalmaz reprezentatív mennyiségü szenes anyagot, ez lehetőséget ad a Raman spektroszkópiai alapú szenes anyag termométer (Beyssac et al. 2002, Rahl et al. 2005, Aoya et al. 2010) használatára. Mivel a szenes anyag grafitizációja szigorúan irreverzibilis és hőmérséklet függő folyamat, a termométer a kőzetre jellemző, a $P T$ út során maximálisan elért metamorf hőmérsékletet tudja becsülni.

A terület három, uralkodó kőzettípusát destruktív (visszaterheléses egyirányú nyomóvizsgálat, Brazil vagy húzóvizsgálat) és nem destruktív (UH sebesség) kőzetmechanikai teszteknek vetettük alá, illetve 3-dimenziós CT (Computed Tomography) felvételek készültek a roncsolás előtti és utáni állapotokról. A mintatestek foliációval párhuzamosan és foliációra merőlegesen lettek kialakítva, így a törési hajlam irány függőségét is tudtuk vizsgálni. Az így mesterségesen kialakított töréshálózat mennyiségi (kumulatív repedés hossz) és geometriai (fraktál dimenzió érték) tulajdonságai, illetve a törésteszt során kapott mérőszámok (nyomószilárdság; húzószilárdság; Young vagy rugalmassági modulus; relatív térfogat változás; törési munka) jellemzik a kőzettípusok lehetséges vezető és/vagy tároló képességét.

A geológiai információ térbeli kiterjesztéséhez a rendelkezésre álló több évtizedes lukgeofizikai szelvények (gamma, ellenállás, neutron, sürüség és akusztikus szelvények) digitalizált adatsorait használtuk. A korábban elkülönített kőzettípusokat hagyományos cross plotokkal, a litológia érzékeny MN plottal (Schlumberger, 1989) és diszkriminancia analízíssel azonosítottuk, majd a kutak menti kiterjesztéssel becsültük a litológiai határokat. Az így kapott kőzettípus határokat földtani szelvények mentén ábrázoltuk, hogy feltáruljon a területet felépítő kőzettestek geometriája és szerkezeti felépítése. 


\section{Az eredmények tézisszerü összefoglalása}

A dolgozatban bemutatott kutatás során az alábbi új tudományos eredmények születtek:

1.) A Kiskunhalas-ÉK mezőben négy fő kőzettípust különítettünk el, melyek a kutakban tapasztalt szomszédsági viszonyok alapján az ideális kőzetoszlopban alulról felfelé a következők: ortogneisz, ortogneisz milonit, grafitos gneisz milonit és grafitos karbonát fillit.

2.) A legalsó ismert szerkezeti helyzetben lévő ortogneisz test amfibolit xenolitot és csillám mentes granitoid teléreket tartalmaz. Ásványos összetétele és mélységi magmás szöveti reliktumok (mirmekit, saját alakú cirkon) alapján feltételezzük, hogy a szomszédos Jánoshalma ortogneisszel azonos, melyet $T<580{ }^{\circ} \mathrm{C}$ metamorf átalakulási hőmérséklet jellemez. Ez az ortogneisz a protolitja, a milonit zóna alsó részét alkotó ortogneisz milonitnak, az ásványos összetétel és a jellegzetes mélységi magmás szövet jelenléte alapján.

3.) A milonit zónát felépítő másik litológia jellemző index ásványai (grafit, pirit) miatt egyértelmủen elkülönül az alsó ortogneisztöl. Nem deformált protolitja a területen ismeretlen; hasonlóan elkülönül a legfelső szerkezeti helyzetben előforduló grafitos karbonát fillittől, annak nagy kvarc+földpát+szericit tartalma miatt. A Raman spektroszkópiás szenes anyag termométerrel meghatározott jellemző metamorf hőmérséklete $T=410 \pm 45^{\circ} \mathrm{C}$.

4.) A viszonylag kis kiterjedésü, legfelső szerkezeti helyzetben lévő grafitos karbonát fillit jellegzetes, kaotikusan gyürt sötét (szenes anyag, pirit, agyagásványok) és világos (karbonát, szericit, kevés kvarc) sávokból áll. A Raman spektroszkópiás szenes anyag termométerrel meghatározott jellemző metamorf hőmérséklete $T=375 \pm 15^{\circ} \mathrm{C}$.

5.) A kőzettest jelentős részét adó milonitos zóna petrológiailag két különböző kőzettípusból épül fel. Ezek egységesen olyan szöveti bélyegeket viselnek magukon, melyek arra utalnak, hogy a milonitosodás során mikro léptékben extenziós feszültségtér alakult ki. A mindkét litológiai egységre alkalmazott kvarc szutúra termométerrel meghatározott deformáció kori hőmérsékletük azonosan körülbelül $T_{d e f} \sim 455^{\circ} \mathrm{C}$-nak adódott.

6.) $\mathrm{Az}$ inkompatibilis kőzetoszlop mentén közel $200{ }^{\circ} \mathrm{C}$ metamorf hőmérséklet különbség jelentkezik. A milonitosodott kőzettípusokban becsült deformációs hőmérséklet alapján, a geotermikus gradienstől függően, hozzávetőlegesen $15 \mathrm{~km}$ mélyen egy vetőzóna müködése során kerülhettek egymás mellé, a mai sorrendbe a kőzetoszlopot felépítő kőzettestek. Bár 
a milonitokban leírt extenziós feszültségtérben kialakult szöveti bélyegek jelenléte, nem zárja ki az egész kőzettest vonatkozásában a kompressziós feszültségteret, mindazonáltal inkább azt valószínüsíti, hogy az egykori nyírási zóna extenziós feszültségtérben müködhetett.

7.) Három, a területen uralkodó kőzettípus (ortogneisz, ortogneisz milonit, grafitos gneisz milonit) kőzetmechanikai vizsgálatai azt mutatják, hogy azok rezervoár tulajdonságai szignifikánsan különböznek. A legjobb tároló tulajdonsággal a grafitos gneisz milonit bír, mely nagy és kommunikáló töréshálózat kialakulására hajlamos, melyet kevesebb befektetett munkával lehet elérni a többi litológiához képest (ortogneisz, ortogneisz milonit). Jellemző továbbá a mért paraméterek nagy anizotrópiája, a milonitos foliációval párhuzamosan tört minták rezervoár szempontból jellemzően kedvezőbb tulajdonságokat mutatnak, szemben a foliációra merőleges mintákkal.

8.) A rendelkezésre álló karotázs szelvény adatsorok alapján el tudtuk különíteni adott kutak mentén az ortogneiszt a milonittól, melyben az ellenállás és a sürüség szelvény játszott döntő szerepet, illetve a grafitos karbonát fillitet a milonittól. A két kőzettanilag elkülönülő milonitosodott kőzettípus (ortogneisz milonit, grafitos gneisz milonit) a rendelkezésre álló lukgeofizikai adatok alapján nem elkülöníthető. Ilyen módon három litológiai egység (ortogneisz, milonit, grafitos karbonát fillit) között becsültünk litológia határokat, melyeket földtani szelvényen ábrázoltunk.

9.) Az így kapott földtani szelvényeken a gneisz/milonit határ lapos szögü $\left(<5^{\circ}\right)$, északias dőlésü $\left(13-18^{\circ}\right)$ síknak adódik, melyet a nyírási zóna két oldalán felismert kőzettestek szignifikánsan eltérő metamorf fejlődéstörténete alapján elválasztó vetőként értelmeztünk.

10.) A hidraulikai rezsimek figyelembe vételével a szelvényeken a későbbi töréses deformáció eredményeként kialakult néhány normál vető azonosítható, melyek rekesztőként viselkednek a termelő tulajdonságú milonitos testek között. Egyes rezsim határokat azonban nem vető, hanem feltételezhetően a milonit zóna kőzettani inhomogenitása okozhat. Mivel a két milonitosodott kőzettípus törési hajlama szignifikánsan eltér, ez jelentős különbségeket eredményezhet a tároló kapacitásban. A tároló testek geometriáját, s így rezervoár tulajdonságait tovább árnyalhatja a milonitok számottevő szerkezeti, s az ehhez kapcsolódó kőzetmechanikai anizotrópiája. 


\section{ACKNOWLEDGEMENTS}

"I have planted, Apollos watered; but God gave the increase."

(The First Epistle of Paul the Apostle to the Corinthians 3,6)

First, and above all I would like to give praise and thanks to God, the Almighty for the "increase". The Lord has given me His blessings and power throughout my life, and I am grateful for His support in completing this study.

I would like to express my sincere and profound gratitude to my supervisor Tivadar $M$. Tóth for the "planting" and the "watering". His enjoyable lectures drew my attention to the wonderful world of geology and petrology, and his illustrative examples frequently helped me to find the way in the labyrinth of science. I am grateful for his invaluable and continuing assistance, thoughtful guidance, understanding, trust, patience, knowledge and also his critical comments. It was a great privilege and honour to work and study under his guidance. I feel motivated and encouraged every time I attend his meetings. I would also like to thank him for his friendship, wisdom, and great sense of humour. Aside from the subject of my research, I learnt a lot from him, which I am sure will be useful in different stages of my life.

I would like to thank Félix Schubert for his valuable suggestions, advice and expertise. Andrea Varga; thanks for the very useful discussions on the work (and others). Gergö Dabi, beside your friendly assistance, I greatly appreciate his excellent taste of music which provided a good atmosphere in the office.

I would like to thank all the members of the Fractured Reservoir Group for the knowledgebase that accumulated in the course of their work, and the professional and industrial relationships formed. I am grateful for their co-operation, and according to my best hope maybe I could enrich this society with my work.

I appreciate the assistance provided in numerous ways by all the staff in the Department of Mineralogy, Geochemistry and Petrology, University of Szeged. Thanks to Krisztián Fintor for guidance with the Raman spectroscopy. Thank you very much to all my colleagues for their help and useful discussions. I also thank all the teachers and classmates of my graduate and $\mathrm{PhD}$ study who inspired and encouraged me.

MOL Plc. is acknowledged for providing samples, well-log data, additional information, and for releasing the papers resulting from this study. Many thanks to Balázs Kiss for his interest, the fruitful discussions and help. I would like to express my thanks to Ilona Vargáné 
Tóth for her expertise and excellent help with the well-logs. I am grateful to Balázs Vásárhelyi for the useful discussions and help in the rock mechanical test evaluation. Tamás Földes is acknowledged for co-operation with the CT scans.

I sincerely acknowledge the Institute of Geography and Geology, University of Szeged for giving me the opportunity to carry out this research and for their financial support granted through a pre-doctoral fellowship. This work was supported with a fellowship of TÁMOP4.2.2/B-10/1-2010-0012 ("Broadening the knowledge base and supporting the long term professional sustainability of the Research University Centre of Excellence at the University of Szeged by ensuring the rising generation of excellent scientists") and TÁMOP 4.2.4. A/211-1-2012-0001 ("National Excellence Program - Elaborating and operating an inland student and researcher personal support system convergence program"). The project was subsidized by the European Union and co-financed by the European Social Fund.

I am extremely grateful to my husband, Béci for his continuous incessant encouragement and patience; without his love, prayers and spiritual support this would not have been possible.

I warmly thank and appreciate all the wisdom, love and support given to me in all aspects of my life, for that I am eternally grateful to my beloved Mom and Dad, Grandma and Grandpa. I take this moment to express my never ending love and respect towards them. It is sad that some of them are not able to take part in sharing the joy of this attainment.

I also wish to thank all of my dear friends, especially Gabi Pócsi for common experiences, to Rita Kamera for the coffee times, to Csilla Tari for her unique personality, to Andi Rónavári for her friendship and to Janina Horváth remembering our trips.

There are so many others whom I may have inadvertently left out and I sincerely thank all of those who helped and supported my work directly or indirectly. 


\section{REFERENCES}

Aguilera R. (1995): Naturally fractured reservoirs. 2nd Edition. Penwell Publishing Company, Tulsa, Oklahoma.

Al-Hadhrami H. S., Blunt M. J. (2001): Thermally Induced Wettability Alteration To Improve Oil Recovery in Fractured Reservoirs. SPE Reservoir Evaluation \& Engineering, 4/3, 179-186.

Antonellini M., Aydin A., Pollard D. D., D’Onfro P. (1994): Petrophysical study of faults in sandstone using petrographic image analysis and X-ray computerized tomography. Pure Appl. Geophys., 143, 181-201.

Aoya M., Kouketsu Y., Endo S., Shimizu H., Mizukami T., Nakamura D., Wallis S. (2010): Extending the applicability of the Raman carbonaceous-material geothermometer using data from contact metamorphic rocks. J Metamorph Geol 28/9, 895-914.

Areshev E. G., Dong T. L., San N. T., Shnip O. A. (1992): Reservoirs in fractured basement on the continental shelf of southern Vietnam. Journal of Petroleum Geology, 15/4, 451464.

Árkai P. (1978): A Kiskunhalas ÉK-I terület mezozoikumnál idősebb metamorf és magmás képződményeinek szénhidrogénprognózist elősegítő ásványtan-kőzettani és geokémiai vizságlata (Mineralogical-petrological investigation of the igneous and metamorphic formations of the Kiskunhalas-NE region older than Mesozoic to improve hydrocarbon prognostics). MTA GKI (Manuscript).

Árkai P. (1991): Kishőmérsékletü regionális metamorfózis (Low temperature regional metamorphism). DSc Thesis. Budapest.

Árkai P. (1993): The distinction between low-T retrograde metamorphism and weathering + burial diagenesis of the gneiss and mica schist basement complex, Great Plain, Hungary: A novel use of illite "crystallinity". Neues Jahrbuch für Mineralogie, Monatshefte, H. 8, 337-351.

Asquith G., Krygowsky D. (2004): Porosity Logs. In.: Basic Well Log Analysis: AAPG Methods in Exploraion 16, 37-76.

ASTM (2004): Annual Book of ASTM Standards, 4/ 08, Soil and Rock. American Society for Testing and Materials, Philadelphia, PA.

Aydin A. (2000): Fractures, faults, and hydrocarbon entrapment, migration and flow. Marine and Petroleum Geology, 17/7, 797-814.

Balogh K., M. Tóth T., Dunk1 I., Scherrer N. (2009): A polimetamorf aljzat geokronológiai viszonyai a Szeghalom és a Mezősas-Furta háton. (Gechronology of the polymetamorphic basement in the Szeghalom and Mezősas-Furta highs.) In: M. Tóth, T. (ed.): Magmás és metamorf képződmények a Tiszai Egységben. GeoLitera, 147-160.

Barton C. C. (1995): Fractal analysis of scaling and spatial clustering of fractures. In: Barton C. C., La Pointe P. R. (eds.): Fractals in the Earth Sciences. Plenum Press, New York, 168. 
Barton C. C., Larsen E. (1985): Fractal geometry of two-dimensional fracture networks at Yucca Mountain, Southwestern Nevada. In: Stephanson O (ed.): Proc. Int. Symp. on Fundamentals of Rock Joints, 77-84.

Barton N. R., Lien R., Lunde J. (1974): Engineering classification of rock masses for the design of tunnel support. Rock Mech. and Rock Eng. 4, 189-236.

Batzle M. L., Simmons G., Siegfried R. W. (1980): Microcrack closure in rocks under stress: direct observation. J. of Geophy. Res., 85/B12, 7072-7090.

Be'suelle P., Baud P., Wong T.-F. (2003): Failure mode and spatial distribution of damage in Rothbach Sandstone in the brittle-ductile transition. Pure appl. geophys., 160, 851-868

Becker S. P., Eichhubl P., Laubach S. E., Reed R. M., Lander R. H., Bodnar R. J. (2010): A 48 my history of fracture opening, temperature, and fluid pressure: Cretaceous Travis Peak Formation, East Texas basin. Geological Society of America Bulletin, 122/7-8, 1081-1093.

Benaouda D., Wadge G., Whitmarsh R. B., Rothwell R. G., Macleod C. (1999): Inferring the lithology of borehole rocks by applying neural network classifiers to downhole logs: an example from the Ocean Drilling Program. Geophy. J. Int. 136, 477-491.

Beyssac O., Goffé B., Chopin C., Rouzaud N. (2002): Raman spectra of carbonaceous material in metasediments: a new geothermometer. J. Met. Geol., 20, 859-871.

Beyssac, O., Goffé B., Petitet J.-P., Froigneux E., Moreau M., Rouzaud J.-N. (2003): On the characterization of disordered and heterogeneous carbonaceous materials by Raman spectroscopy. Spectrochimica Acta Part A, 59, 2267-2276.

Beyssac, O., Bollinger L., Avouac J-P., Goffé B. (2004): Thermal metamorphism in the lesser Himalaya of Nepal determined from Raman spectroscopy of carbonaceous material. Earth and Planetary Science Letters, 225, 233- 241.

Bieniawski Z. T. (1967): Mechanism of brittle fracture of rock, parts I, II and III. Int. J. Rock Mech. Min. Sc.i Geomech. Abstr. 4/4, 395-430.

Bieniawski Z. T. (1989): Engineering rock mass classifications: a complete manual for engineers and geologists in mining, civil, and petroleum engineering. WileyInterscience. $40-47$.

Bleahu M., Haas J., Kovács S., Péró Cs., Mantea G., Bordea S., Panin S., Bérczi-Makk A., Stefanescu M., Konrád Gy., Nagy E., Rálisch-Felgenhauer E., Sikic K., Török Á. (1994): Triassic facies types evolution and paleogeographic relations of the Tisza megunit. Acta Geologicy Hungarica, 37, 187-234.

Bryon D. N., Atherton M. P., Hunter R. H. (1995): The interpretation of granitic textures from serial thin sectioning, image analysis and three-dimensional reconstruction. Mineral. Mag., 59, 203-11.

Cai M. (2010): Practical estimates of tensile strength and Hoek-Brown strength parameter mi of brittle Rocks. Rock Mech. Rock Eng. 43/2, 167-184. 
Cai M., Kaiser P. K., Tasaka Y., Maejima T., Morioka H., Minami M. (2004): Generalized crack initiation and crack damage stress thresholds of brittle rock masses near underground excavations. Int. J. Rock Mech. Min. Sci., 41/5, 833-847.

Carlson W. D., Denison C., Ketcham R. A. (2000): High-resolution X-ray computed tomography as a tool for visualization and quantitative analysis of igneous textures in three dimensions. Visual Geosciences, 4/3, 1-14.

Cooper M. R., Hunter R. H. (1995): Precision serial lapping, imaging and three-dimensional reconstruction of minus-cement and post-cementation intergranular pore-systems in the Penrith Sandstone of north-western England. Mineral. Mag., 59, 213-20.

Cserepes L. (1980): A Duna-Tisza Közi karbonnál idősebb képződmények petrológiai vizsgálata (Petrologic study of the formations older than Carboniferous of the DanubeTisza Interfluve). MSZKFI, Budapest.

Cserepes-Meszéna B 1986: Petrography of the crystalline basement of the Danube-Tisza Interfluve (Hungary). Acta Geol. Hung., 29/3-4, 321-339.

Csontos L., Nagymarosy A. (1998): The Mid-Hungarian line: a zone of repeated tectonic inversions. Tectonophysics 297/1-4, 51-71.

Csontos L., Nagymarosy A., Horváth F., Kovac M. (1992): Tertiary evolution of the IntraCarpathian area: a model. Tectonophysics, 208, 221-241.

D. Lörincz K. (1996): Feszültségtér történet meghatározása szeizmikus szelvényeken azonosított többfázisú tektonizmus alapján, a Szolnoki flis öv nyugati peremén. Magyar Geofizika, 37/4, 228-246.

Dank V. (1985): Kőolajföldtan (Petroleum Geology), Tankönyvkiadó Budapest. Manuscript.

Deere D. U., Miller R. P. (1966): Engineering classification and index properties of intact rock. Tech. Report No. AFWL-TR-65-116, Air Force.

Denison C., Carlson W. D., (1997): Three-dimensional quantitative textural analysis of metamorphic rocks using high-resolution computed X-ray tomography: Part II. Application to natural samples. J. of Met. Geol., 15/1, 45-57.

Denison C., Carlson W. D., Ketcham R. A. (1997): Three-dimensional quantitative textural analysis of metamorphic rocks using high-resolution computed X-ray tomography: Part I. Methods and techniques. J. of Met. Geol., 15/1, 29-44.

Dunkl I. (1994): Fission track evidence on the Pliocene-Quaternary uplift of the margin of the Pannonin basin (Hungary). Proc. of Internat. Conf. on Geochronology, Cosmochronology and Isotope Geology, Berkeley, 5-11. June 1994.

Edwards H. E., Becker A. D., Howell J. A. (1993): Compartmentalization of an aeolian sandstone by structural heterogeneities: permo-Triassic Hopeman Sandstone, Moray Firth, Scotland. Geological Society, London, Special Publications, 73/1, 339-365.

Feng Z. Q. (2008): Volcanic rocks as prolific gas reservoir: A case study from the Qingshen gas field in the Songliao Basin, NE China. Marine and Petroleum Geology, 25/4, 416432. 
Földes T., Árgyelán G. B., Kiss B., Hips K., Bogner P., Repa I. (2004): Application of medical Computer Tomograph measurement to 3D reservoir characterization. Acta Geol. Hung., 47/1, 63-73.

Gercek H. (2007): Poisson's ratio values of rocks, Int. J. Rock Mech. Mining Sci., 44, 1-13.

Gottschalk R. R. (1990): Mechanical anisotropy of gneiss: Failure criterion and textural sources of directional behavior. J. of Geophysical Research, 95/B13, 21613-21634.

Gu J., Jia J., Fang H. (2002): Reservoir characteristics and genesis of high-porosity and highpermeability reservoirs in Tarim Basin. Chinese Science Bulletin, 47/1, 12-19.

Gudmundsson A. (1987). Geometry, formation and development of tectonic fractures on the Reykjanes Peninsula, southwest Iceland. Tectonophysics,139/3, 295-308.

Gudmundsson A., Berg S. S., Lyslo K. B., Skurtveit E. (2001): Fracture networks and fluid transport in active fault zones. Journal of Structural Geology, 23/2, 343-353.

Haas J., Budai T., Csontos L., Fodor L., Konrád Gy. (2010): Pre-Cenozoic geological map of Hungary, 1:500 000. Geological Institute of Hungary.

Haas J., Péró Cs. (2004): Mesozoic evolution of the Tisza Mega-unit. Int J Earth Sci 93/2, 297-313

Hajnal Z., Reilkoff B., Posgay K., Hegedus E., Takacs E., Asudeh I., Mueller J. Ansorge R, DeIaco R. (1996): Crustal-scale extension in the central Pannonian basin. Tectonophysics, 264/1-4, 191-204.

Heffer K. J, Lean J (1993): Earth stress orientation — a control on, and a guide to, flooding directionality in a majority of reservoirs. W Linville (Ed.), Reservoir Characterization III, PennWell Books, Tulsa, 799-822.

Hirata T. (1989): Fractal dimension of fault system in Japan: fracture structure in rock fracture geometry at various scales. Pure and Applied Geophysics, 131, 157-170.

Hirth G., J. Tullis (1992): Dislocation creep regimes in quartz aggregates. - Journal of Structural Geology, 14, 145-159.

Horváth F. (1995): Phases of compression during the evolution of the Pannonian Basin and its bearing on hydrocarbon exploration. Mar Petroleum Geol 12/8, 837-844.

Horváth F., Dövényi P., Szalay Á., Royden L. H. (1988): Subsidence, thermal and maturation history of the Greatr Hungarian Plain. In Royden, L. H. and Horváth, F. (eds.): The Pannonian Basin: A Study in Basin Evolution. AAPG Memoir, 43, 355-372.

Horváth F., Bada G., Szafián P., Tari G., Ádám A., Cloetingh S. (2006): Formation and deformation of the Pannonian Basin: constraints from observational data. In: Gee DG, Stephenson RA (eds) European lithosphere dynamics. Geological Society, London, Memoirs 32, 191-206.

Horváth F., Dunkl I., M. Tóth T., Tari G., Bada G. (2006): Surface vs. Moho topography and the core complex mode of extension in the Pannonian basin. Geophysical Research Abstracts, 8, 04290. 
Horváth F., Tari G. (2002): in: Mészáros E.-Schweitzer: Magyar tudománytár 1. - Föld, víz, levegő, Kossuth Könyvkiadó.

Hounsfield G. N. (1973): Computerized traverse axial scanning (tomography). Br. J. Radiol., 46, 1016-1022.

Huddlestone-Holmes C. R., Ketcham R. A. (2010): An X-ray computed tomography study of inclusion trail orientations in multiple porphyroblasts from a single sample. Tectonophysics, 480, 305-320.

Ianovici V., Borcos M., Bleahu R., Patrulius D., Lupu M., Dimitrescu R., Savu H. (1976): La géologie des Monts Apuseni. Editions de Academi, Bucuresti.

Ikeda S., Nakano T., Nakashima Y. (2000): Three-dimensional study on the interconnection and shape of crystals in a graphic granite by X-ray CT and image analysis. Mineral. Mag., 64/5, 945-959.

ISRM (2006): The complete ISRM suggested methods for rock characterization, testing and monitoring. Eds: Ulusay R.; Hudson J. A., ISRM, 628.

Jaeger J. C., Cook N. G. W., Zimmermann R. W. (2007): Fundamentals of Rock Mechanics (Fourth Edition). Blackwell Publishing, 475.

Jánosi T., M. Tóth T., Jánosi Zs. (2007): Kvarc szutúra mintázatok képanalízise és termometriai alkalmazásuk (Image analysis and termometrical application of quartz suture patterns). Bányászati, Kohászati és Földtani Konferencia, Buziásfürfő, 206-209.

Juhász A., M Tóth T., Ramseyer K., Matter A. (2002): Connected fluid evolution in fractured crystalline basement and overlying sediments, Pannonian Basin, SE Hungary. Chemical Geology, 182, 91-120.

Kawakata H., Cho A., Kiyama T., Yanagidani T., Kusunose K., Shimada M. (1999): Threedimensional observations of faulting process in Westerly Granite under uniaxial and triaxial conditions by X-ray CT scan. Tectonophysics, 313, 293-305.

Ketcham R. A. (2005): Three-dimensional grain fabric measurements using high-resolution X-ray computed tomography. J. of Struct. Geol., 27, 1217-1228.

Ketcham R. A., Carlson W. D. (2001): Acquisition, optimization and interpretation of X-ray computed tomographic imagery: applications to the geosciences. Comp. \& Geosci., 27, 381-400.

Kovács S., Haas J., Császár G., Szederkényi T., Buda Gy., Nagymarosy A. (2000): Tectonostratigraphic terranes in the pre-Neogene basement of the Hungarian part of the Pannonian area. Acta Geol Hung 43, 225-328.

Kruhl J. H., Nega M. 1996: The fractal shape of sutured quartz grain boundaries: application as a geothermometer. Geol. Rundsch, 85, 38-43.

Kwiecinska B., Suárez-Ruiz I., Paluszkiewicz C., Rodriques S. (2010): Raman spectroscopy of selected carbonaceous samples. International Journal of Coal Geology, 84, 206-212. 
Lahfid, A., Beyssac O., Deville E., Negro F., Chopin C., Goffé B. (2010): Evolution of the Raman spectrum of carbonaceous material in low-grade metasediments of the Glarus Alps (Switzerland). Terra Nova, 22, 354-360.

Laubach S. E., Olson J. E., Gale J. F. (2004): Are open fractures necessarily aligned with maximum horizontal stress? Earth and Planetary Science Letters, 222/1, 191-195.

Lelkes-Felvári Gy., Frank W. 2006: Geochronology of the metamorphic basement, Transdanubian part of the Tisza Mega-Unit. Acta Geol. Hung. 49/3, 189-206.

Lelkes-Felvári Gy., Frank W., Schuster R. (2003): Geochronological constraints of the Variscan, Permian-Triassic and eo-Alpine (Cretaceous) evolution of the Great Hungarian Plain basement. - Geol. Carpathica, 54/5, 299-315.

Lelkes-Felvári Gy., Schuster R., Frank W., Sassi R. (2005): Metamorphic history of the Algyő High (Tisza Mega-unit, basement of Great Hungarian Plain) - a counterpart of crystalline units of the Koralpe-Wölz nappe system (Austroalpine, Eastern Alps). Acta Geologica Hungarica, 48/4, 371-394.

Li J., Du Q., Sun C. (2009): An improved box-counting method for image fractal dimension estimation. Pattern Recognition, 42/11, 2460-2469.

Li X. G., Liu B. H., Cai G. G. (2009): Genetic analysis of interior reservoirs in metamorphic buried hill of Liaohe Depression [J]. Special Oil \& Gas Reservoirs, 4, 002.

Lister G. S., Davis G. A. (1989): The origin of metamorphic core complexes and detachment faults formed during Tertiary continental extension in the northern Colorado River region, U.S.A. J of Structural Geol 11/1-2, 65-94.

Liu Q., Brosch F. J., Riedmüller G. (2004): The significance and prediction of different rock mass characteristics for rock engineering. Int. J. of Rock Mech. and Mining Sci., 41/1, 103-117.

Luo J., Morad S., Liang Z., Zhu Y. (2005): Controls on the quality of Archean metamorphic and Jurassic volcanic reservoir rocks from the Xinglongtai buried hill, western depression of Liaohe basin, China. AAPG bulletin, 89/10, 1319-1346.

Lü X., Yang N., Zhou X., Yang H., Li J. (2008): Influence of Ordovician carbonate reservoir beds in Tarim Basin by faulting. Science in China Series D: Earth Sciences, 51/2, 53 60 .

M. Tóth T. (2013): Evolution of the Körös Complex orthogneiss, Tisza Megaunit, SE Hungary. Submitted to Lithos.

M. Tóth T., Schubert F., Földes T., Hollós Cs., Komlósi J. (2002): Modelling of the fractured Dorozsma crystalline reservoir, SE Pannonian Basin. EAGE Annual Meeting Abstracts 297.

M. Tóth T., Szűcs É., Schubert F., Hollós Cs. (2004): Conceptual fracture network model of the crystalline basement of the Szeghalom Dome (Pannonian Basin, SE Hungary). Acta Geol Hung 47/1, 19-34. 
M. Tóth T., Zachar J. (2006): Petrology and deformation history of the metamorphic basement in the Mezősas-Furta crystalline high (SE Hungary). Acta Geol. Hung., 49/2, 165-188.

M. Tóth T., Vass I., Szanyi J., Kovács B. (2007): Water and heat flow through uplifted metamorphic highs in the basement of the Pannonian Basin. XXXV. IAH Congress, Lisbon, Groundwater and Ecosystems, Proceedings, 1-10.

M. Tóth T., Redlerné Tátrai M., Kummer I. (2009): A Szeghalom környéki metamorf aljzat kiemelkedés szerkezetfejlődése és felépítése kőzettani és szezmikus adatok alapján. Magyar Geofizika, 49/4, 143-151.

Majumder S., Mamtani M. A. (2009): Fractal Analysis of quartz grain boundary sutures in a granite (Malanjkhand, Central India) Implications on Infer Regional Tectonics. Journal Geological Society of India, 73, 309-319.

Mandelbrot, B. B. (1967): How long is the coast of Britain? Statistical self-similarity and fractional dimension. Science, 156, 636-638.

Marschallinger R. (1998): Correction of geometric errors associated with the 3-D reconstruction of geological materials by precision serial lapping. Mineral. Mag., 62, 783-92.

Martin C. D. (1993): The strength of massive Lac du Bonnet granite around underground opening. Ph.D. Thesis.

Masuda T., Fujimura A. (1981): Microstructural development of fine-quartz aggregates by syntectonic recrystallization. Tectonophysics, 72, 105-128.

Matsumoto N., Yomogida K., Honda S. (1992): Fractal analysis of fault systems in Japan and the Philippines. Geophysical Research Letters, 19/4, 357-360.

McNaughton D. A., Garb F. A. (1975): Finding and Evaluating Petroleum Accumulations in Fractured Reservoir Rock. Exploration and Economics of the Petroleum Industry, 13, 45-54.

Mees F., Swennen R., Van Geet M., Jacobs P. (2003): Applications of X-ray computed tomography in the geosciences. Geological Society, London, Special Publications, 215, $1-6$.

Molnár L., M. Tóth T., Schubert F. (2013): Discrimination of brittle and semi-brittle tectonite types at borecore scale using geometric parameters. Submitted to: Journal of Structural Geology.

Nagy Á., M. Tóth T. (2009): Relikt szöveti elemek a Görcsönyi Formáció óriásgránátos gneisz tagozat mintáiban (Relict fabric elements in the gneiss samples of Görcsöny Formation). In: M. Tóth, T. ed.: Igneous and metamorphic formations of the Tisza Unit. GeoLitera, [ISSN 2060-7067], 65-79. (in hungarian)

Nagy Á., M. Tóth T. (2012) Petrology and tectonic evolution of the Kiskunhalas-NE fractured CH-reservoir. S-Hung Cent Eur Geol 55/1, 1-22

Nagy Á., M. Tóth T. (2012): A Kömpöc - Csólyos-K repedezett szénhidrogén mező kőzettani és szerkezeti felépítése (Petrlogical and sturctural buil up of the Kömpöc - Csólyos-K 
fractured hydrocarbon reservoir). III. Congress of Petrology and Geochemistry Telkibánya, Hungary 22 pp (in hungarian)

Nagy Á., M. Tóth T., Vásárhelyi B., Földes T. (2013): Integrated core study of a fractured metamorphic HC-reservoir; Kiskunhalas-NE, Pannonian Basin. Acta Geod Geophys. 48/1, 53-75.

Nelson R. (2001): Geologic analysis of naturally fractured reservoirs. Gulf Professional Publishing.

Nelson R. A., Moldovanyi E. P., Matcek C. C., Azpiritxaga I., Bueno E. (2000): Production characteristics of the fractured reservoirs of the La Paz field, Maracaibo basin, Venezuela. AAPG bulletin, 84/11, 1791-1809.

Nemanich R.J., Solin S. A. (1979): First- and second-order Raman scattering from finite-size crystals of graphite. Physical Review B, 20, 392-401.

Német-Varga Z. (1983): Tectonics of the Mecsek Mountains in the Apline orogenic cycle. Annual Report Hungary Geological Survey, 1981, 467-484.

Ortega O. J., Marrett R. A., Laubach S. E. (2006): A scale-independent approach to fracture intensity and average spacing measurement. AAPG Bulletin, 90/2,193 - 208

Pan D. E. N. G., Mengjin C., Zherong G., Ai S. (2002): Log response and explanation of structural fractures in volcanic rock reservoir [J]. Acta Petrolei Sinica, 6, 009.

Passchier C. W., Trouw R. A. J. (2005): Microtecnotics. Springer, Berlin Heidelberg.

Philpotts A. R., Shi J., Brustman C. (1998): Role of plagioclase crystal chains in the differentiation of partly crystallized basaltic magma. Nature, 395, 343-346.

Posgay K., Bodoky T., Hajnal Z., M. Tóth T., Fancsik T., Hegedűs E., Cs. Kovács A., Takács E. (2006): Interpretation of subhorizontal crustal reflections by metamorphic and rheologic effects in the eastern part of the Pannonian Basin. Geophys. J. Int. 167, 187203.

Rabcewicz L. (1964): The New Austrian Tunnelling Method, Part one. Water Power, November 1964, 453-457, Part two, Water Power, December 1964, 511-515.

Rahl J., Anderson K., Brandon M., Fassoulas C. (2005): Raman spectroscopic carbonaceous material thermometry of low-grade metamorphic rocks: Calibration and application to tectonic exhumation in Crete, Greece. Earth and Planetary Sci. Letters, 240/2, 339-354.

Rantitsch G., Sachsenhofer R. F., Hasenhuttl C., Russegger B., Rainer T. (2005): Thermal evolution of an extensional detachment as constrained by organic metamorphic data and thermal modeling: Graz Paleozoic Nappe Complex (Eastern Alps). Tectonophysics, $411,57-72$.

Raynaud S., Fabre D., Mazetolle F., Geraud Y., Latiere H. J. (1989): Analysis of the Internal Structure of Rocks and Characterization of Mechanical Deformation by a Nondestructive Method: X-ray Tomodensitometry. Tectonophysics, 159, 149-159.

Riden M. H. (1996): Lithology Reconstruction from logs. In: Geological Interpretation of Well Logs, 2nd Edition Whittles Publishing. 151-168. 
Rozlozsnik P. (1936): Die tektonische Stellung der bihargebirgsgruppe (Muntii Apuseni) im Karpatensystem. Math. und Naturwissenschaft, anzeiger Budapest, 55, 46-76.

Salah M. G., Alsharhan A. S. (1998): The Precambrian basement: a major reservoir in the rifted basin, Gulf of Suez. Journal of Petroleum Science and Engineering, 19/3, 201222.

Schlumberger (1989): Log Interpretation Principles/Applications. Schlumberger Wireline \& Testing, Texas.

Schubert F., Diamond L. W., M. Tóth T. (2007): Fluid inclusion evidence of petroleum migration through a buried metamorphic dome in the Pannonian Basin, Hungary. Chemical Geology, 244/3-4, 357-381.

Schubert F., M. Tóth T. (2001): Structural evolution of mylonitized gneiss zone from the Norther flank of the Szeghalom dome (Pannonian Basin, SE, Hungary). Acta Min. Pet. Szeged, 42, 59-64.

Schubert F., M. Tóth T. (2002): Structural evolution of mylonitized gneiss zone from the Norther flank of the Szeghalom dome (Pannonian Basin, SE, Hungary). Acta Min. Pet. Szeged, 42, 59- 64.

Schubert F., M. Tóth T. (2003): Successive, Isothermal Hydrocarbon Migration Events Recorded by Fluid Inclusions in Fracture-Filling Quartz of the Szeghalom Dome (SE Hungary) Acta Mineralogica-Petrographica, Szeged, 44, 9-17.

Schutter S. R. (2003): Hydrocarbon occurrence and exploration in and around igneous rocks. Geological Society, London, Special Publications, 214/1, 7-33.

Seo Y. S., Jeong G. C., Kim J. S., Ichikawa Y. (2002): Microscopic observation and contact stress analysis of granite under compression. Engineering Geology, 63/3-4, 259-275.

Sruoga P., Rubinstein N. (2007): Processes controlling porosity and permeability in volcanic reservoirs from the Austral and Neuquen basins, Argentina. AAPG bulletin, 91/1, 115129.

Steckhan J., Sauer R. (2010): Introduction of a Rock Typing Methodology in Crystalline Basement Reservoirs (Yemen). Extended abstract of AAPG International Conference and Exhibition, Rio de Janeiro, Brazil, November 15-18, 2009

Stegena L., Horváth F., Landy I., Nagy Z., Rumpler J. (1992): High enthalpy geothermal reservoirs in Hungary. Földtani Közlöny, 122/2-4, 195-208.

Szederkényi T. (1984): Az Alföld kristályos aljzata és földtani kapcsolatai. DSc Thesis. Szeged.

Szederkényi T. (1996): Metamorphic formations and their correlation in the Hungarian part of the Tisza Megaunit (Tisza Composite Terrane). Acta Min Petr Szeged 37, 143-160

Szederkényi T., Árkai P., Lelkes-Felvári Gy. (1991): Crystalline groundfloor of the Great Hungarian Plain and South Transdanubia. In: Karamata, S. (ed.): Geodynamic evolution of the Pannonian Basin, 261-273. 
Szepesházy K. (1973): A Duna Tisza Köze déli részének metamorf kőzetei. A MÁFI évi jelentése az 1973. évről, 147-166.

T. Kovács G. (1973): A Duna-Tisza köze déli részének földtani fejlődés története (Geological evolution of the southern part of the Danube-Tisza Interfluve). DSc Thesis. Szeged

T. Kovács G., Kurucz B. (1984): A dél-alföld mezozoikumnál id"osebb képz"odményei (Formations older than Mezozoic of the Southern Great Hungarian Plain). MÁFI, Budapest.

Takahashi M., Nagahama H., Masuda T., Fujimura A. (1998): Fractal analysis of experimentally, dynamically recrystallized quartz grains and its possible application as a strain rate meter. Journal of Structural Geology, 20/2-3, 269-275.

Tari G., Horváth F., Rumpler J. (1992): Styles of extension in the Pannonian Basin. Tectonophysics 208, 203-219

Tari G., Dövényi P., Dunkl I., Horváth F., Lenkey L., Stefanescu M., Szafián P., Tóth T. (1999): Lithospheric structure of the Pannonian basin derived from seismic, gravity and geothermal data. Geological Society, London, Special Publications; 156, 215-250.

Teleki P. G., Mattick R. E., Kókai J. (Eds.). (1994):Basin Analysis in Petroleum Exploration: A Case Study from the Békés Basin, Hungary. Springer.

Teufel L.W, Rhett D.W, Farrell H.E (1991): Effect of reservoir depletion and pore pressure drawdown on in situ stress and deformation in the Ekofisk field, North Sea. Proc. U.S. Rock Mech. Symp., 32, 63-72.

Tittman J,. Wahl J.S. (1965): The physical foundations of formation density logging (gammagamma). Geophysics 30/2, 284-294.

Tsuchiya N., Nakatsuka K. (1995): A two-dimensional mono-fractal approach to natural fracture networks in rock. Geotherm. Sci. Tech., 6, 63-82.

Tuinstra F., Koenig J.L. (1970): Raman spectrum of graphite. Journal of Chemical Physics, $53,1126-1130$.

Van Geet M., Swennen R., Wevers M. (2000): Quantitative analysis of reservoir rocks by microfocus X-ray computerised tomography. Sedimentary Geology, 132, 25-36.

Vass I., M. Tóth T., Szanyi J., Kovács B. (2009): Az aljzat kristályos hátának szerepe az Alföld fluidum áramlási és hőtransport folyamataiban. In.: M. Tóth T ed.: Igneous and metamorphic formations of the Tisza Unit. GeoLitera, 325-339.

Vinegar H. J., De Waal J. A., Wellington S. L. (1991): CT Studies of Brittle Failure in Castlegat Sandstone. Int. J. Rock Mech. Min. Sci., 28, 441-448.

Voll G. (1980): Ein Querprofil durch die Schweizer Alpen vom Vierwaldstatter See zur Wurzelzone-Strukturen und ihre Entwicklung durch Defomationsmechanismen wichtiger Minerale. Neues Jahrbuch für Geologie und Paläontologie, Abhandlungen, 160,. 321-335.

Wellington S. L., Vinegar H. J. (1987): X-Ray Computerized Tomography. J. Pet. Tech., 39, 885-898. 
White S. H., Knipe R. J. (1978): Transformation- and reaction-enhanced ductility in rocks. Journal of the Geological Society, 135/5, 513-516.

Whitney D. L., Ewans B. W. (2010): Abbreviations for names of rock-forming minerals. American Mineralogist, 95, 185-187.

Wibberley C. (1999): Are feldspar-to-mica reactions necessarily reaction-softening processes in fault zones? J. of Struct. Geol., 21/8-9, 1219-1227.

Wiederkehr M., Bousquet R., Ziemann M. A., Berger A., Schmid S. M. (2011): 3-D assessment of peak-metamorphic conditions by Raman spectroscopy of carbonaceous material: an example from the margin of the Lepontine dome (Swiss Central Alps). Int. J. Earth Sci. (Geol Rundsch), 100/5, 1029-1063.

Williams G., Dixon J. (1982): Reaction and Geometrical Softening in Granitoid Mylonites. Textures and Microstructures, 4/4, 223-239.

Wopenka B., Pasteris J. D. (1993): Structural characterization of kerogens to granulite-facies graphite: Applicability of Raman microprobe spectroscopy. American Mineralogist, 78, 533-557.

Yui T.F., Huang E., Xu J. (1996): Raman spectrum of carbonaceous material: a possible metamorphic grade indicator for low-grade metamorphic rocks. J. Metamorph Geol., $14,115-124$.

Zachar J., M. Tóth T. (2001): Myrmekite-bearing gneiss from the Szeghalom Dome (Pannonian Basin, SE Hungary) Part II.: Origin and spatial relationships. Acta Min. Pet. Szeged, 42, 39-43.

Zachar J., T. M. Tóth (2004): Pertology of the metamorphic basement of the Tisza Block at the Jánoshalma High, S Hungary. Acta Geologica Hungarica, 47/4, 349-371.

Zachar J., M. Tóth T., Janák M. (2007): Kyanite eclogite xenolith from the orthogneiss terrane of the Tisza Megaunit, Jánoshalma area, crystalline basement of southern Hungary. Lithos, 99/3-4, 249-265.

Zellou A. M., Hartley L. J., Hoogerduijn-Strating E. H., Dhahab S. H. H., Boom W., Hadrami F. (2003): Integrated Workflow Applied to the Characterization of a Carbonate Fractured Reservoir: Qarn Alam Field. Middle East Oil Show. 